\begin{abstract}
UNIVERSIDADE DE SÃO PAULO
FACULDADE DE FILOSOFIA LETRAS E CIÊNCIAS HUMANAS DEPARTAMENTO DE GEOGRAFIA

PROGRAMA DE PÓS-GRADUAÇÃO EM GEOGRAFIA FÍSICA
\end{abstract}

RODOLFO ALVES DA LUZ

Geomorfologia da Planície Fluvial do Rio Pinheiros entre os Bairros de Pinheiros, Butantã e Cidade Jardim, São Paulo (SP). 


\author{
UNIVERSIDADE DE SÃO PAULO \\ FACULDADE DE FILOSOFIA LETRAS E CIÊNCIAS HUMANAS \\ DEPARTAMENTO DE GEOGRAFIA \\ PROGRAMA DE PÓS-GRADUAÇÃO EM GEOGRAFIA FÍSICA
}

\title{
Geomorfologia da Planície Fluvial do Rio Pinheiros entre os Bairros de Pinheiros, Butantã e Cidade Jardim, São Paulo (SP).
}

Dissertação de mestrado apresentada ao Programa de Pós-Graduação em Geografia Física, do Departamento de Geografia, da Faculdade de Filosofia, Letras e Ciências Humanas da Universidade de São Paulo, para a obtenção do título de Mestre em Geografia Física.

Orientadora: Profa. Dra. Cleide Rodrigues 
ERRATA:

Página IV: Onde se lê "Geomorfologia da Planície Fluvial Meândrica do Rio Pinheiros entre os Bairros de Pinheiros, Butantã e Cidade Jardim, São Paulo (SP)", leia-se "Geomorfologia da Planície Fluvial do Rio Pinheiros entre os Bairros de Pinheiros, Butantã e Cidade Jardim, São Paulo (SP)". 
Aos meus pais Renato e Maria Creusa, pelo carinho, amor e educação que me ofereceram e ainda oferecem 


\section{Agradecimentos}

À Professora Cleide Rodrigues pela seriedade, orientação, ensinamentos e, principalmente, pela amizade.

À Coordenação de Aperfeiçoamento de Pessoal de Nível Superior (CAPES) e ao Programa de Pós-Graduação em Geografia Física pela bolsa de estudos.

Aos funcionários da secretária de pós-graduação pela atenção prestada.

Às professoras Sidneide Manfredini e Lylian Coltrinari pelas contribuições preciosas no exame de qualificação.

À Professora Rosely Pachedo Dias Ferreira pela amizade e por ser uma das maiores responsáveis pela minha formação acadêmica.

À Maria Isabel Torres da Fundação Energia e Saneamento pelo pronto atendimento quando da aquisição das fotografias aéreas.

Ao geólogo Hugo Rocha do Metrô de São Paulo pela disponibilização das sondagens geológicas.

À Documento Antropologia e Arqueologia S/S Ltda. por tornar possível o acesso às escavações do Metrô.

Às dezenas de operários do Metrô que ajudaram nas escavações dos perfis verticais.

Ao Laerte (Enc. Administrativo) e ao "Zezão" (mestre de obras) por liberar o acesso a obra e as sondagens geológicas da Rua Diogo Moreira.

Aos Engenheiros Paulo Magro e Eduardo da Construtora São José por liberar o acesso a obra e as sondagens geológicas da Rua Seridó

Ao Luiz Franco, Alexandre Daffre, Tulius Nery e William Santos, grandes amigos que ajudaram nos trabalhos de campo.

Ao geógrafo Marcos Pinheiros pela atenção e pronto atendimento no Laboratório de Pedologia.

À Deborah Carvalho por tirar dúvidas a respeito de dados históricos do rio Pinheiros.

À Neide Farran pela compreensão e amizade.

Ao Sandro, Ana e seus funcionários pelo auxílio na impressão e formatação.

Aos meus familiares em Osasco, São Paulo, Curitiba e Aquidauana, por mostrarem que juntos a vida é mais divertida.

À minha esposa e grande companheira Marta, elemento vital na transformação de meus sonhos em realidade. 


\section{Geomorfologia da Planície Fluvial Meândrica do Rio Pinheiros entre os Bairros de Pinheiros, Butantã e Cidade Jardim, São Paulo (SP).}

Resumo:

Na presente pesquisa investiga-se a geomorfologia da planície fluvial do rio Pinheiros entre os bairros de Pinheiros, Butantã e Cidade Jardim, na cidade de São Paulo. Para tal, propõe-se uma carta geomorfológica de detalhe deste setor da planície na escala de 1:20.000, confeccionada a partir de pesquisa arquivística prévia e, principalmente, de fotografias aéreas e de mapas antigos. A análise da carta e a sua correlação com informações sedimentológicas e estratigráficas encontradas, principalmente, em recentes relatórios de engenharia para a construção do Metrô de São Paulo, permitem a caracterização do sistema fluvial deste setor do rio Pinheiros, bem como de parte da morfodinâmica atuante no sistema antes da perturbação antrópica de alto impacto decorrente da urbanização que ali se instalou a partir da década de 1930.

A pesquisa permitiu também a interpretação de uma provável sequência de eventos geomorfológicos atuantes no setor estudado durante o Pleistoceno Superior e o Holoceno. Parâmetros morfométricos tais como índice de sinuosidade de canais e paleocanais e largura da planície no trecho estudado evidenciaram aspectos da influência da estrutura geológica em sua evolução.

O reconhecimento de sistemas geomorfológicos em seu estágio préperturbação antrópica é essencial para a compreensão dos processos atuais, principalmente em meios intensamente modificados como as áreas urbanas. A pesquisa apresenta então este tipo de reconhecimento, colaborando assim na compreensão dos processos antecedentes às grandes rupturas que se instalam no sistema a partir das ações antrópicas na superfície.

Palavras-chave: Geomorfologia Fluvial; Cartografia Geomorfológica; Geomorfologia de São Paulo; Rio Pinheiros; Sistemas Meândricos. 
Abstract:

This research investigates the geomorphology of part of Pinheiros River fluvial plain in São Paulo city. This study main result is a detailed geomorphologic map - 1:20,000 - that used ancient aerial photographs and maps obtained from formal archival surveys. The descriptions of floodplain units were associated to stratigraphic and sedimentologic data obtained from recent engineering projects reports of São Paulo underground (such as subway). This association allows the understanding of part of Pinheiros River fluvial system and morphodynamic before urbanization.

The research also allowed offering a sequence of geomorphological events related to the floodplain and channel systems over the Holocene. Morphometric parameters, such as width and sinuosity index of channels and paleo-channels of floodplain meandering system, appear as an evidence of the structural influence in geomorphological evolution of this system.

The recognition of geomorphologic systems in pre-disturbance stage is essential for understanding the current processes, mainly in environments greatly modified by human actions, such as urban areas. This research presents this kind of recognition and contributes to the understanding of processes in the system before human actions in the surface.

Key-words: Fluvial Geomorphology; Geomorphologic Mapping; Geomorphology of São Paulo; Pinheiros River; Meandering Systems. 
Sumário

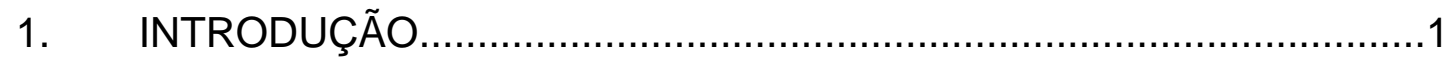

1.1. JUSTIFICATIVAS, OBJETIVOS, E ESCOLHA DA ÁREA DE

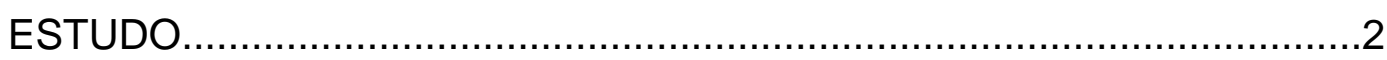

2. CONTEXTO GEOLÓGICO-GEOMORFOLÓGICO REGIONAL............6

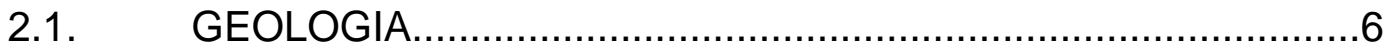

2.1.1. Sedimentos da planície fluvial do rio Pinheiros.......................11

2.2. GEOMORFOLOGIA ..................................................

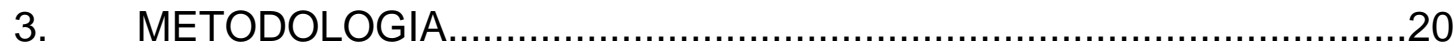

3.1. REFERENCIAL TEÓRICO METODOLÓGICO.......................20

3.1.1. Mapeamento geomorfológico............................................21

3.1.2. Geomorfologia fluvial.....................................................22

3.1.3. Sistemas meândricos.......................................................24

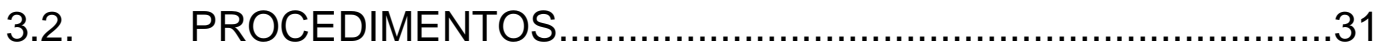

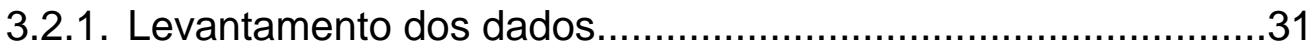

3.2.1.1. Dados cartográficos...........................................31

3.2.1.2. Dados sobre os materiais superficiais........................35

3.2.2. Sistematização de Dados.....................................................39

3.2.3. Análises e Correlações..................................................40

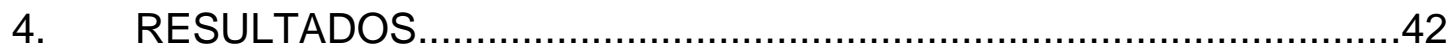

4.1. NÍVEL DESCRITIVO E ANALÍTICO ....................................42

4.1.1. Formas: unidades morfológicas identificadas.......................42

4.1.2. Materiais correlacionados as formas..................................46 
4.1.2.1. Perfil Morfo-sedimentológico Pinheiros-Butantã

4.1.2.2. Outros locais investigados.

4.2. INTERPRETAÇÕES

GEOMORFOLÓGICAS.

.72

4.2.1. Carta Geomorfológica de Detalhe da Planície Fluvial do Rio Pinheiros entre os Bairros de Pinheiros, Butantã e Cidade Jardim .72

4.2.2. Aspectos morfogenéticos da planície fluvial 84

5. CONSIDERAÇÕES

FINAIS. 89

6. BIBLIOGRAFIA. .91

7. ANEXOS 


\section{Lista de Figuras}

Figura 1 - Localização da área de estudo.

Figura 2 - Rift Continental do Sudeste Brasileiro. Fonte: Riccomini et al. (2004).

Figura 3 - Compartimentação tectônica do embasamento pré-cambriano no entorno da Bacia Sedimentar de São Paulo com destaque para a área de estudo. Fonte: Hasui \& Sadowski (1976)................................................

Figura 4 - Mapa Geológico da Bacia Hidrográfica do Alto Tietê.....................8

Figura 5 - Estratigrafia do segmento central do RCSB, que inclui a Bacia de São Paulo. Fonte: Riccomini et al. (2004)...

Figura 6 - Correlação entre a sedimentação quaternária no Município de São Paulo, idades, paleoclimas e paleovegetação segundo Takiya (1997)..........13

Figura 7 - Mapa geomorfológico da Região Metropolitana de São Paulo. Adaptado de Batista (2003) e Rodrigues (2006)...

Figura 8 - Perfil geológico da Linha 4 Amarela do Metrô de São Paulo e compartimentos geomorfológicos.

Figura 9 - Mapa geomorfológico de Ab'Saber (1957) com a localização da área de estudo e da Linha 4 do Metrô (conforme perfil geológico da figura 8). 16

Figura 20 - Padrões de canal e sistemas deposicionais associados. Modificado de Miall (1996)......

Figura 11 - Migração lateral em sistemas meândricos e faciologia resultante.

A) Diagrama representando a construção progressiva de uma planície de inundação, modificado de Knighton (1998). B) Modelo faciológico de deposição de rios meandrantes, modificado de Walker (1983).

Figura 12 - Croqui esquemático de uma planície fluvial com os subsistemas e formas associadas.

Figura 13 - Bloco diagrama mostrando os principais elementos morfológicos

dos sistemas meândricos. Modificado de Walker (1983).

Figura 14 - Tipos de abandonos de canal em sistemas meândricos.

Modificado de Christofoletti (1981).

Figura 15 - Sedimentação de uma barra de acresção. Formação de uma zona de separação adjacente à margem convexa e deposição de finos. Modificado de Nanson (1980).

Figura 16 - Principais parâmetros geométricos de um canal meândrico. Modificado de Christofoletti (1974) e Mangelsdorf et al. (1990). .28

Figura 17 - Experimentos de laboratório que mostram a influência da estrutura geológica (tectônica e litologia) em canais meândricos. 30 
Figura 18 - Mapa-índice das fotografias aéreas utilizadas

Figura 19 - Locais das sondagens geológicas utilizadas e perfis verticais observados

Figura 20 - Unidades morfológicas da área.

Figura 21 - Aspectos geométricos do canal do rio Pinheiros e meandros abandonados

Figura 22 - Perfil Morfo-sedimentológico Pinheiros-Butantã

Figura 23 - Perfil Vertical FL................................................................

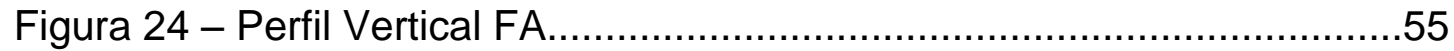

Figura 25 - Formação Itaquaquecetuba no Perfil Morfo-sedimentológico

Pinheiros

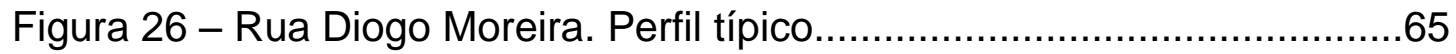

Figura 27 - Rua Diogo Moreira. Perfil Vertical DM....................................66

Figura 28 (legenda) - Chave de interpretação das sondagens geológicas da Rua Seridó 68

Figura 28 - Sondagens geológicas da Rua Seridó......................................69

Figura 29 - Perfil Vertical SE...............................................................

Figura 30 - Carta Geomorfológica da Planície Fluvial do Rio Pinheiros entre os Bairros de Pinheiros, Butantã e Cidade Jardim........................................75

Figura 31 - Croquis esquemáticos da mudança de sinuosidade em parte do canal do rio Pinheiros ocorrida no Quaternário. 


\section{Lista de Tabelas}

Tabela 1 - Índice de sinuosidade e largura do canal a montante e a jusante do setor de estreitamento da planície de inundação do rio Pinheiros

Tabela 2 - Continuação da legenda da Carta Geomorfológica da Planície Fluvial do Rio Pinheiros entre os Bairros de Pinheiros, Butantã e Cidade Jardim

Tabela 3 - Índice de sinuosidade e largura do canal fluvial ativo do rio Pinheiros e do paleocanal a montante do ponto de estreitamento da planície de inundação.

Tabela 4 - Índice de sinuosidade e largura do canal fluvial ativo do rio Pinheiros a jusante e a montante do ponto de estreitamento da planície de inundação.

\section{Lista de Quadros}

Quadro 1: Fotografias aéreas utilizadas

\section{Lista de Pranchas de Fotografias}

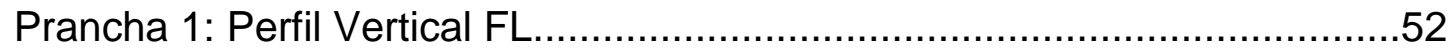

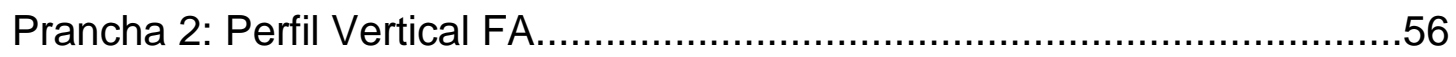

Prancha 3: Rua Diogo Moreira..................................................................

Prancha 4: Perfil Vertical SE.................................................................

Prancha 5: Planície fluvial do rio Pinheiros.......................................................77

Prancha 6: Aspectos de algumas unidades morfológicas..............................78 


\section{INTRODUÇÃO}

Parte da Região Metropolitana de São Paulo (RMSP) assenta-se sobre a bacia hidrográfica do rio Pinheiros. O trecho inferior desta bacia hidrográfica caracteriza-se por uma ocupação urbana densa que tem modificado drasticamente as características fluviais deste rio desde o início do século XX. $\mathrm{O}$ antigo canal fluvial meândrico do rio Pinheiros hoje encontra-se retificado e sua antiga planície de inundação está sob, em média, 2 metros de aterros, desde o início da década de 1940 (CARVALHO, 2006).

Desta maneira que a planície fluvial do Pinheiros tornou-se parte da malha urbana da cidade, configurando-se atualmente como um espaço de redes de serviços urbanos, sendo um importante eixo de circulação da cidade, com ferrovias, vias expressas, redes de esgoto, redes elétricas, etc. (SEABRA, 1987; OSEKI, 2000).

Estudos ambientais em áreas intensamente modificadas por ações antrópicas, como os de áreas urbanas, demandam o reconhecimento das condições ambientais representativas de estágios anteriores às mudanças antropogênicas, ou do reconhecimento de sistemas análogos bem preservados, para que os parâmetros representativos dos processos antecedentes às grandes rupturas sejam obtidos (RODRIGUES, 1997b, p. 142).

Isso se faz necessário para que a gênese dos novos balanços e dos tipos de processos que se instalam a partir das ações antrópicas na superfície sejam compreendidos. Em Geomorfologia, esse reconhecimento realiza-se pela caracterização dos sistemas geomorfológicos em seu estágio pré-perturbação, que é, fundamentalmente, o momento histórico de predomínio das condições ambientais anteriores à apropriação pelas sociedades industriais (TRICART, 1977, p. 17; TOY \& HADLEY, 1982, p. 4; RODRIGUES, 2004, p. 93-95).

A caracterização geomorfológica representativa do estágio pré-perturbação é a base dos estudos de geomorfologia antropogênica, ramo da Geomorfologia que compreende a atividade humana não apenas como um fator modificador do ambiente, mas sim como um agente central do sistema, ou seja, um efetivo 
agente geomorfológico (NIR, 1983; VERSTAPPEN, 1983; GREGORY, 1985; RODRIGUES, 1997a; HOOKE, 2000; DÁVID \& SZABÓ, 2008).

A presente pesquisa apresenta a reconstituição espacial de parte da planície fluvial do rio Pinheiros no seu estágio pré-perturbação, realizada através da sistematização gráfica e cartográfica de sua morfologia original e dos materiais que a compunham ou que ainda a compõem. Dessa forma, foram abordados os três elementos da geomorfologia pura de acordo com a concepção de Hart (1986): 1) nível descritivo da morfologia a partir da cartografia retrospectiva e fotografias aéreas antigas; 2) nível descritivo dos materiais (originais e antrópicos) a partir da revisão da literatura, da utilização de sondagens geológicas, de levantamentos de campo e de análises de laboratório; 3) nível analítico-interpretativo dos processos a partir da articulação entre os dois níveis anteriores.

\subsection{JUSTIFICATIVAS, ESCOLHA DA ÁREA DE ESTUDO E OBJETIVOS}

Os depósitos fluviais podem servir como arquivos de eventos ocorridos em toda bacia hidrográfica, sendo considerados componentes fundamentais dos registros geológicos e geomorfológicos (CHRISTOFOLETTI, 1974, p. 52; RICCOMINI et al., 2000, p. 192). A despeito disso, é interessante observar que, ao longo de sua história, a pesquisa geomorfológica tem se dedicado mais aos processos erosivos do que aos deposicionais (HART, 1986, p.96). Há também uma significativa escassez de estudos de geomorfologia fluvial em países tropicais e úmidos (MIALL, 1982, p. 10; LATRUBESSE et al., 2005, p. 277) e, principalmente, brasileiros e em ambientes urbanos.

É também neste âmbito de relativa carência científica que a presente pesquisa coloca-se e justifica-se. Tratando-se especificamente do rio Pinheiros, este estudo presta também contribuições inéditas a respeito do conhecimento da História Natural da região onde se situa a metrópole paulista.

Segundo Ab'Saber (1978, p. 18), o rio Pinheiros foi, provavelmente, o rio mais transformado por ação antrópica dentre os rios de ordem superior da cidade de 
São Paulo e, talvez, de todo o mundo tropical devido aos diversos projetos de aproveitamento hidro-energético que nele ocorreram.

Apesar das dificuldades intrínsecas aos estudos que visam reconstituir o meio físico de áreas bastante modificadas por ações antrópicas, as áreas densamente urbanizadas apresentam a vantagem de possuírem dados geomorfológicos relevantes a respeito de seus materiais. Assim, além de arquivos históricos, de material iconográfico, dentre outros, existem sondagens geológicas, escavações e investigações técnicas e ambientais geradas pelas obras ali ocorridas (edifícios, túneis, metrô, etc.). Ambos fornecem dados que permitem a interpretação geomorfológica, uma vez que seja transposta a linguagem técnica-operacional da Engenharia.

O acesso a sondagens geológicas executadas pela Companhia do Metropolitano de São Paulo (METRÔ) para a construção da futura Linha 4 Amarela orientou a delimitação da área de estudo. Esta linha, cruzando transversalmente a planície fluvial do rio Pinheiros nas proximidades da atual ponte Eusébio Matoso, gerou em seu projeto, sondagens relevantes para as interpretações pretendidas.

A partir da localização do eixo da linha do Metrô, delimitou-se aleatoriamente uma área de $2 \mathrm{~km}$ a montante e a jusante, para que as informações fornecidas pelas sondagens permitissem extrapolações espaciais em escala de detalhe. Esta delimitação coincidiu aproximadamente com a planície fluvial do rio Pinheiros entre a atual ponte Cidade Jardim (ou ponte Eng. Roberto R. Zuccolo) à montante, e a ponte da Cidade Universitária, à jusante. Assim, definiu-se o recorte espacial da pesquisa, que é a planície fluvial do rio Pinheiros entre os bairros de Pinheiros, Butantã e Cidade Jardim (Figura 1).

O objetivo principal do estudo foi descrever, caracterizar e mapear a morfologia pré-perturbação e os materiais da planície fluvial, para que, a partir da articulação entre estes dois níveis, fosse possível a interpretação dos processos geomorfológicos atuantes no sistema antes das intervenções antrópicas de alto impacto. Estas análises foram feitas por meio de representações gráficas e cartográficas de detalhe. 
De acordo com Tricart (1977), quando comparados ao sistema vertente, os sistemas fluviais são aqueles que apresentam maior sensibilidade às mudanças de curta duração. Sendo assim, os processos geomorfológicos responsáveis pelas formas e pelos materiais da planície fluvial do rio Pinheiros em seu estágio pré-perturbação ocorreram em sua maioria no final do período Quaternário, testemunhando possíveis eventos ambientais locais e regionais deste período. O recorte temporal da pesquisa envolveu então o Quaternário, principalmente o Pleistoceno Superior e o Holoceno, até as ações antrópicas de alto impacto, ocorridas a partir do início do século XX. 


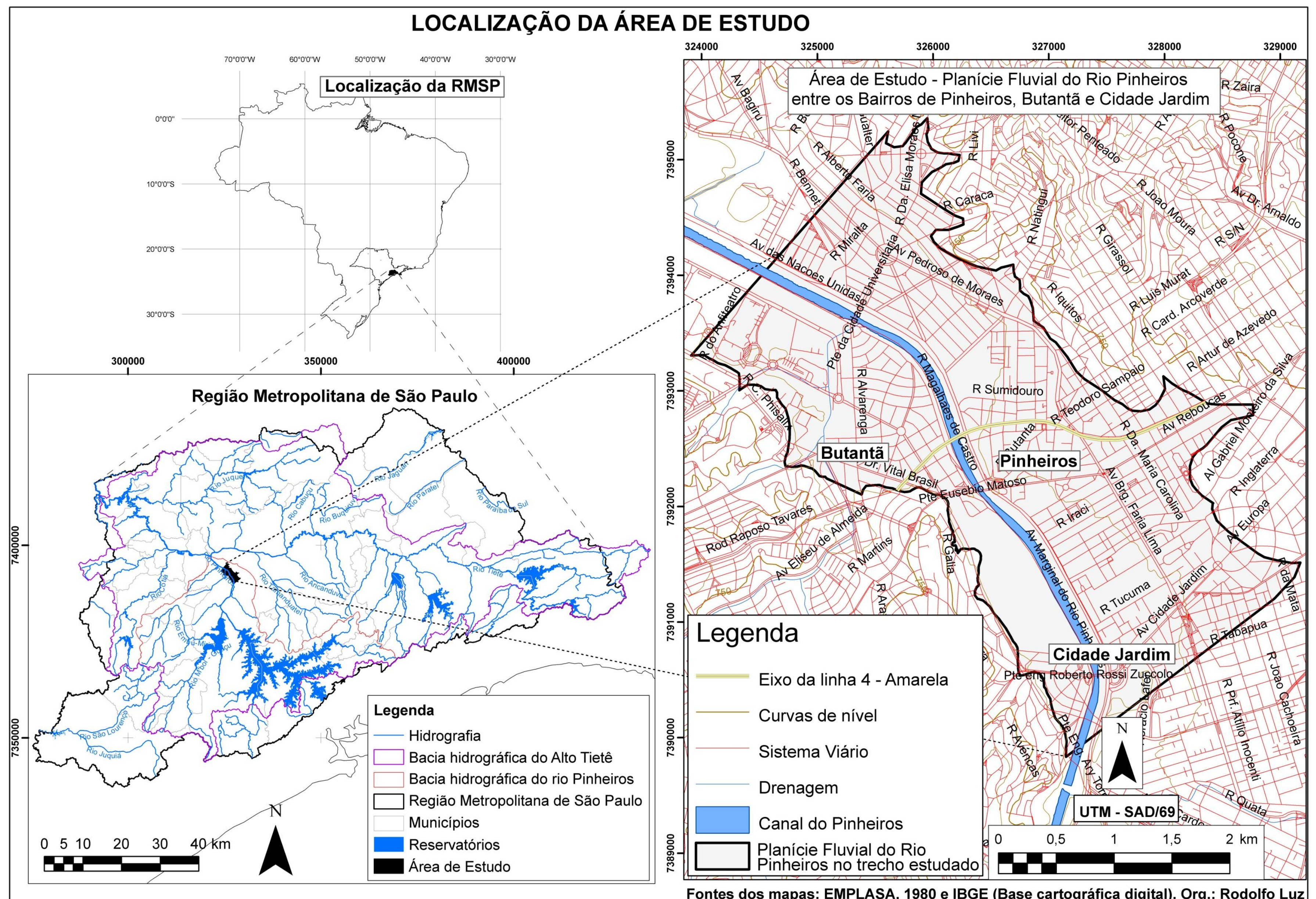

Figura 3 - Localização da área de estudo 


\section{CONTEXTO GEOLÓGICO-GEOMORFOLÓGICO REGIONAL}

\subsection{GEOLOGIA}

A estrutura geológica da fachada atlântica do Sudeste do Brasil compreende terrenos do Cinturão de Dobramentos Ribeira (HASUI et al., 1975), compostos por gnaisses, migmatitos e rochas metamórficas de baixo a médio grau, com diversas suítes granitóides intrusivas e centenas de intrusões de rochas alcalinas. Estas rochas estão seccionadas por zonas de cisalhamento de caráter dextral orientadas segundo E-NE a E-W, ativas até o final do Ciclo Brasiliano (Cambro-Ordoviciano) (SADOWSKI, 1991 apud RICCOMINI et al., 1992, p. 22).

Reativações normais dessas antigas zonas de cisalhamento durante o Terciário (Eoceno-Oligoceno) seriam responsáveis pela origem do Rift Continental do Sudeste do Brasil (RCSB), feição tectônica de idade cenozóica que engloba nove embaciamentos alojados em uma estreita faixa alongada e deprimida entre os Estados do Paraná e Rio de Janeiro (RICCOMINI et al., 1992, p. 22).

Dentre essas bacias está a Bacia de São Paulo que, segundo Riccomini et al. (2004, p. 393-405), se originou após a fragmentação de uma calha tectônica durante o Eoceno e o Mioceno (55 - 5,32 m.a.). Este evento também foi responsável pela individualização das outras bacias sedimentares da porção central do RCSB (Taubaté, Resende e Volta Redonda) (Figura 2).

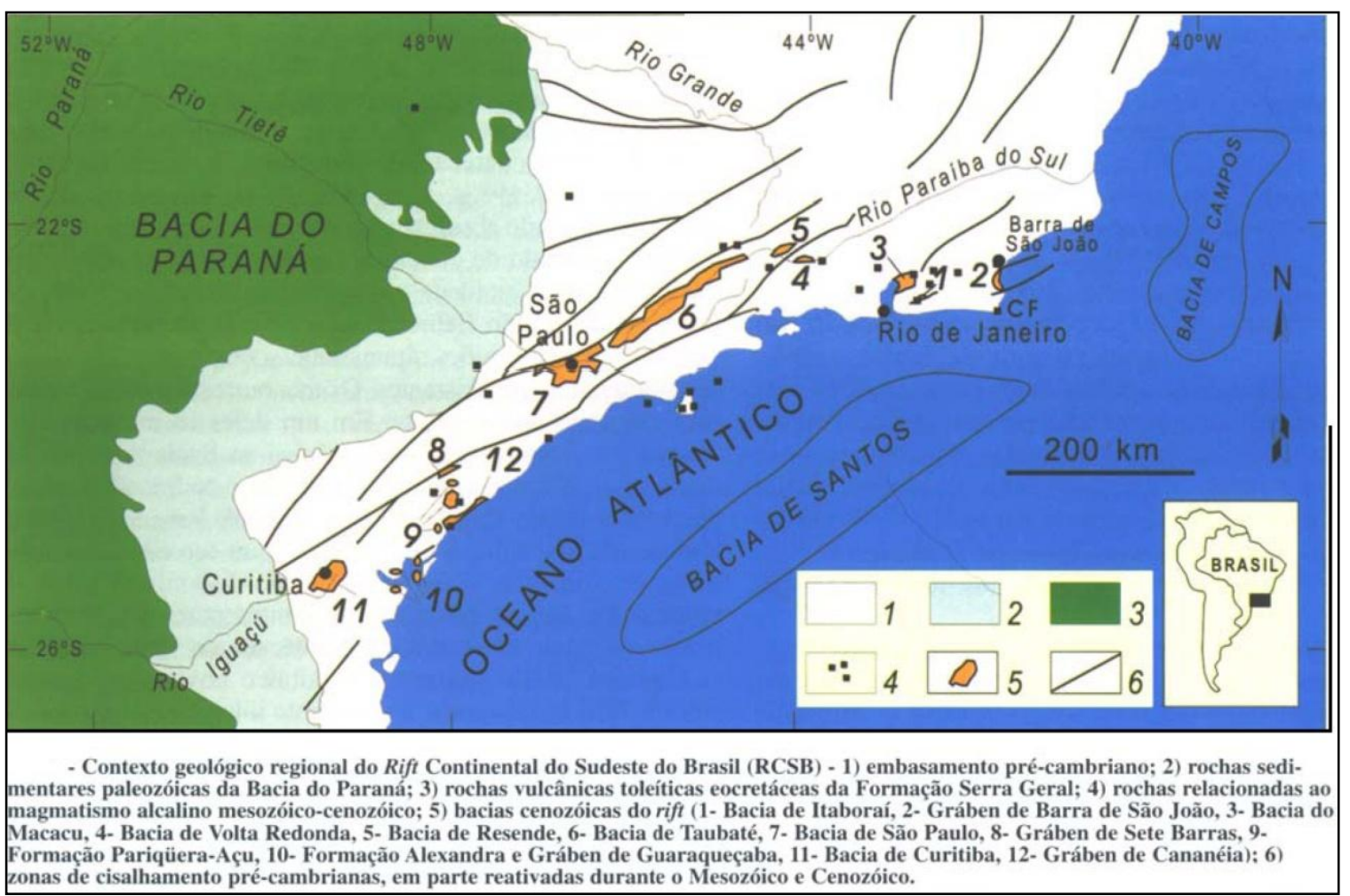

Figura 2 - Rift Continental do Sudeste Brasileiro. Fonte: Riccomini et al. (2004). 
A área de estudo localiza-se na borda oeste da Bacia de São Paulo. Esta bacia corresponde a uma depressão em blocos com cotas mais baixas situadas ao longo da borda norte, onde ocorrem falhas normais reativadas ao longo das zonas de cisalhamento de Taxaquara e Jaguari (HASUI \& CARNEIRO, 1980, p. 11; TAKIYA, 1997, p. 4; RICCOMINI at al., 2004, p. 392).

O embasamento pré-cambriano da Bacia de São Paulo é compartimentado em blocos justapostos limitados por grandes zonas de falhamento transcorrente (HASUI \& SADOWSKI, 1976). As principais falhas que delimitam esses blocos são as de Taxaquara, Caucaia, Jaguari, Buquira e Alto da Fartura. Segundo Hasui \& Carneiro (1980, p. 11) os blocos estariam adernados, com afundamentos em direção ao centro da bacia, como resultado das reativações cenozóicas das antigas zonas de cisalhamento.

Na planície fluvial do rio Pinheiros no setor estudado há dois destes blocos, que são delimitados pela Falha de Caucaia (Figura 3): 1) Bloco Cotia ao norte, com afundamento na sua extremidade leste e; 2) Bloco Juquitiba ao sul, com afundamento de sua porção norte. No entanto, Hasui \& Carneiro (op. cit., p. 11) observam que a subsidência do Bloco Cotia apresentou uma menor amplitude do que o do Bloco Juquitiba.

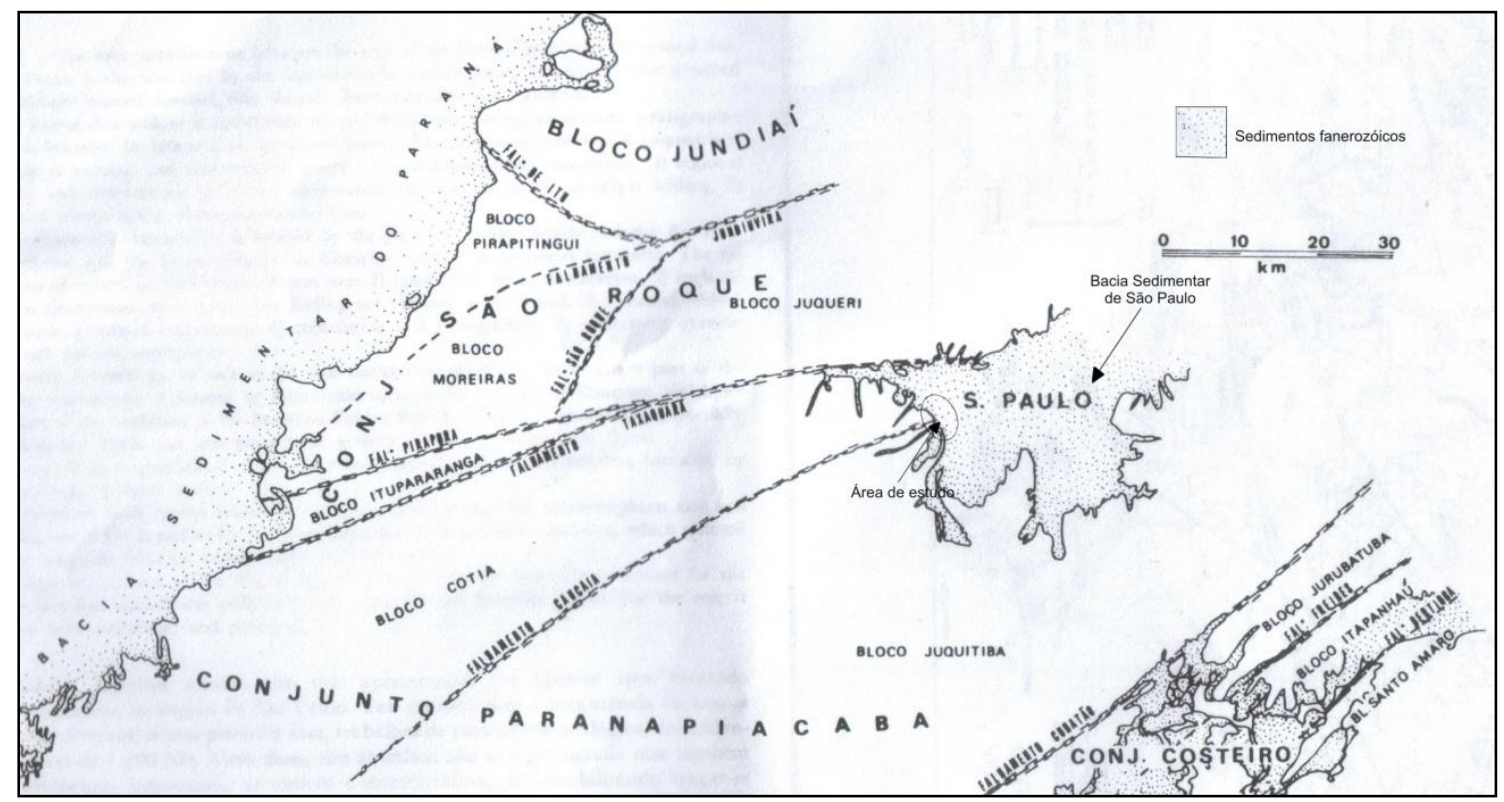

Figura 3 - Compartimentação tectônica do embasamento pré-cambriano no entorno da Bacia Sedimentar de São Paulo com destaque para a área de estudo. Fonte: Hasui \& Sadowski (1976). 


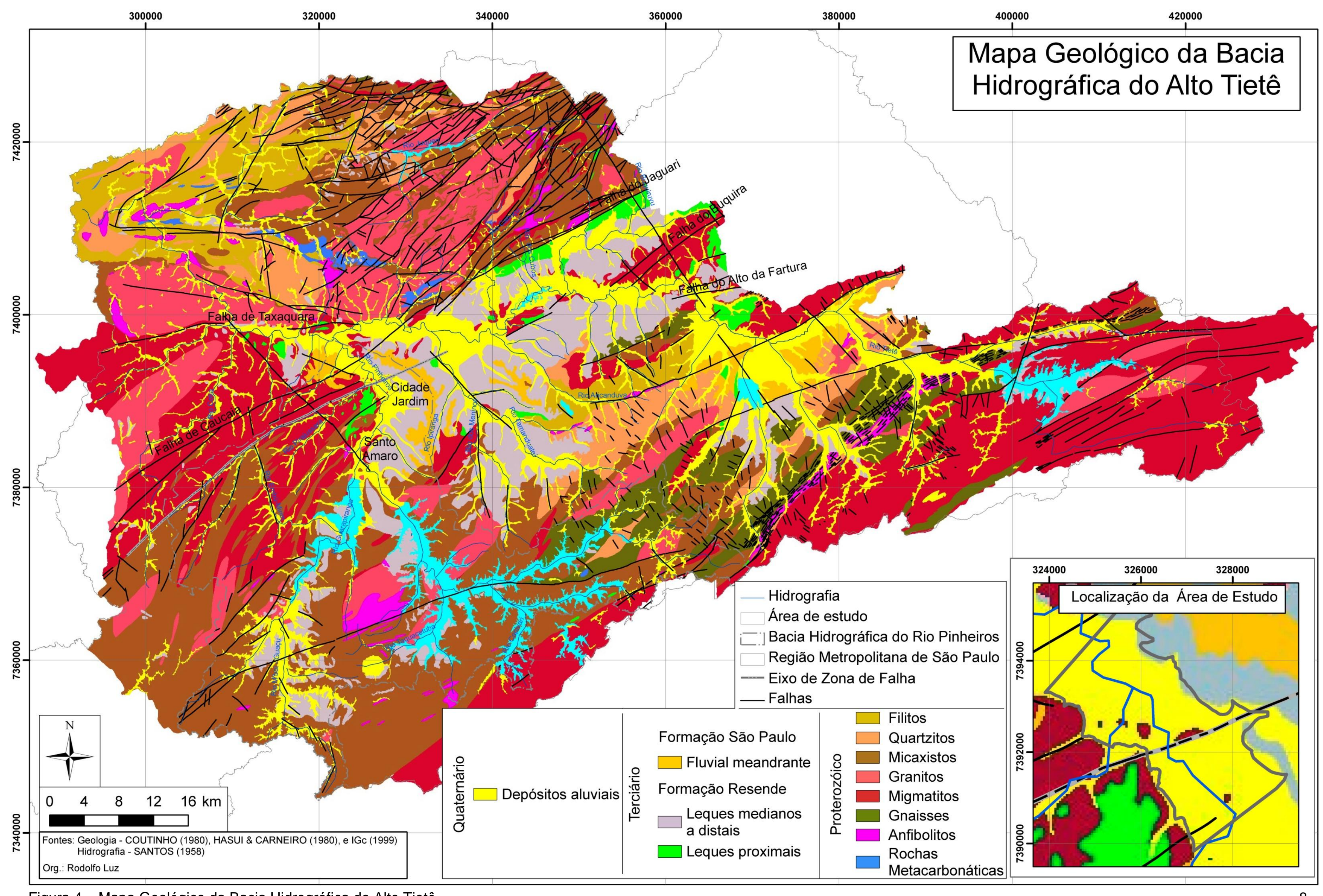

Figura 4 - Mapa Geológico da Bacia Hidrográfica do Alto Tietê 
Litologicamente, Coutinho (1972) considera as áreas desses dois blocos como sendo do Complexo Cristalino, porém, distingue as faixas gnáissicas e graníticas na zona de cisalhamento entre as falhas de Taxaquara e de Caucaia (Bloco Cotia) do restante do complexo, onde predominam os micaxistos.

Segundo Coutinho (1980 e 1984) a Falha de Caucaia estaria localizada um pouco a jusante da área de estudo, mas um eixo de zona de falha atravessa a região central da área de estudo ${ }^{1}$ (Figuras 4). Esta eixo de zona de falha e a Falha de Caucaia delimitam os blocos de Cotia e Juquitiba, determinando a configuração tectônica da planície fluvial do rio Pinheiros na área de estudo.

Portanto, a área de estudo é representativa da zona de contato entre o bloco de Cotia, de menor subsidência e composto por gnaisses, com o bloco de Juquitiba, de maior subsidência e composto predominantemente por micaxistos.

A Bacia de São Paulo é preenchida por sedimentos cenozóicos que apresentam falhas pós-sedimentares relacionadas a soerguimentos e abatimentos locais do substrato durante o Terciário. As unidades paleógenas desses depósitos são encerradas no Grupo Taubaté, onde são reconhecidas as seguintes formações (RICCOMINI et al., 2004., p. 392) (Figura 5):

- Formação Resende: depósitos basais e laterais do Grupo Taubaté (Paleógeno) relacionados a um sistema de leques aluviais associado a planícies aluviais de rios entrelaçados. Nas porções proximais dos leques predominam conglomerados de matriz lamítica a arenosa, e nas porções medianas e distais predominam os lamitos e lamitos arenosos maciços;

- Formação Tremembé: depósitos lacustres oligocênicos resultantes da migração lateral do sistema de leques aluviais da Formação Resende. Ocorre na forma de camadas tabulares de argilitos maciços verdes intercalados com argilitos cinza-escuro a preto, ricos em matéria orgânica.

\footnotetext{
1 Este eixo de zona de falha é denominado de "faixa de cisalhamento" no Mapa Geológico do Atlas Ambiental do Município de São Paulo (PMSP-SVMA-SEMPLA, 2002).
} 
- Formação São Paulo: depósitos do topo do Grupo Taubaté (Oligoceno Superior) relacionados a um sistema fluvial meandrante. As principais litologias correspondem aos ambientes típicos desse tipo de sistema fluvial. Arenitos grossos, conglomeráticos, com estratificações cruzadas e base erosiva representantes de depósitos de canal; siltitos e argilitos laminados depositados em meandros abandonados; arenitos médios a grossos resultantes de depósitos de rompimento de diques; sedimentos finos, rítmicos e laminados de planície de inundação.

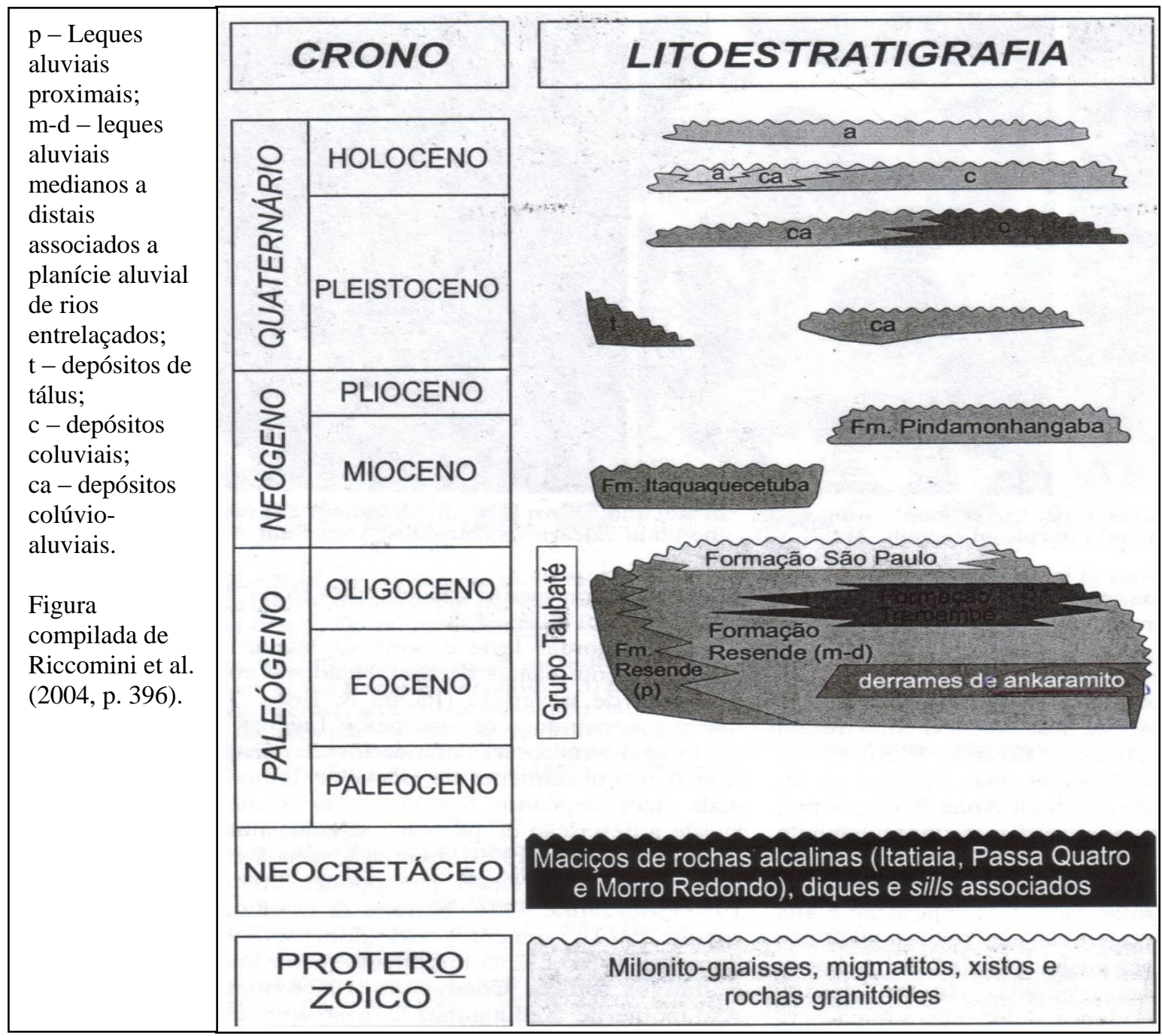

Figura 5 - Estratigrafia do segmento central do RCSB, que inclui a Bacia de São Paulo. Fonte: Riccomini et al. (2004). 


\subsubsection{Sedimentos da planície fluvial do rio Pinheiros}

Uma primeira diferenciação entre os materiais sedimentares que compõem a planície fluvial do rio Pinheiros foi feita por Junqueira (1969), que separou grandes pacotes arenosos com estruturas cruzadas inferiores dos sedimentos mais finos do topo. Naquele momento esse pacote inferior foi interpretado como depósitos de canais entrelaçados realizados sob climas semi-áridos, sendo então denominado de "aluviões antigos dos rios Pinheiros e Tietê" devido à sua ocorrência generalizada em todas as planícies dos grandes rios paulistanos.

Estes depósitos arenosos foram então datados por Carbono $14 \mathrm{em}$ torno de 40.000 a 44.000 A.P. admitindo-se idade máxima de 50.000 A.P. (BIGARELLA, 1971; SUGUIO, 1971), portanto, Pleistoceno Superior. Inicialmente foram considerados de clima úmido com forte influência tectônica, porém, em seguida admitiu-se o clima semi-árido (SUGUIO,1980, p. 29).

Posteriormente, estes depósitos definiram uma unidade estratigráfica, formalizados como Formação Itaquaquecetuba (COIMBRA et al., 1983, p. 254), definida como depósitos típicos de sedimentação fluvial anastomosada (braided) oriundo basicamente das rochas metamórficas do embasamento pré-cambriano em condições de curto transporte. A partir de datações paleomagnéticas que indicaram idades em torno de 730.000 A.P., Melo et al. (1985) reposicionaram a Formação Itaquaquecetuba no Eoceno Superior.

Porém, informações mais recentes têm posicionado a Formação Itaquaquecetuba no Mioceno Inferior (ARAI \& YAMAMOTO, 1995, p. 84) (Figura 5), sendo esta interpretada como representante de um sistema fluvial entrelaçado "que ocorre assentado diretamente sobre rochas do embasamento pré-cambriano, sem que tenha sido verificada a sua relação com unidades sedimentares paleógenas anteriores" (RICCOMINI et al., 2004, p. 401).

A Formação Itaquaquecetuba ocorre, principalmente, abaixo da cota altimétrica de 710 metros sob os sedimentos aluviais dos principais rios paulistanos (MELO et al., 1989, p. 5; TAKIYA, 1997, p. 45). Na planície fluvial do rio Pinheiros, dados de uma sondagem próxima à atual raia olímpica da Cidade 
Universitária, no extremo norte da área de estudo, indicaram mais de 40 metros de espessura para esta formação (TAKIYA 1991 apud TAKIYA, 1997, p. 46).

Em sua constituição litológica predominam arenitos grossos arcoseanos, mal a medianamente selecionados com estratificações cruzadas tabulares e acanaladas. Estes estratos podem conter níveis argilo-siltosos ricos em matéria orgânica e níveis de conglomerados com seixos de quartzo e quartzito bem arredondados (TAKIYA, 1997, p. 45)

Riccomini et al. (1992, p.31) retomam a idéia de climas úmidos vigentes durante a deposição da Formação Itaquaquecetuba. Estudos palinológicos já indicavam espécies de climas úmidos associadas aos seus sedimentos, como tem sido apresentado por Fittipaldi \& Simões (1989) e Fittipaldi (2002).

Acima da Formação Itaquaquecetuba estão os depósitos quaternários relacionados ao estágio pré-perturbação de sedimentação do rio Pinheiros. São predominantemente sedimentos mais finos e menos espessos do que os da Formação Itaquaquecetuba e apresentam contato frequentemente erosivo com esta formação (MELO et al., 1985, p. 177; ALMEIDA et al., 1984). Segundo Riccomini et al. (op. cit., p. 32) os sedimentos fluviais quaternários dos rios paulistanos raramente ultrapassam os 10 metros.

Almeida et al. (1984), Melo et al. (1985) e Melo et al. (1987) caracterizaram estes depósitos como apresentando camadas turfosas no topo que podem alcançar até pouco mais de 1 metro de espessura, sobre camadas de areias finas à médias por vezes com areias grossas a conglomeráticas, sempre tendo como camada basal cascalhos. Takiya (1997, p. 84) salienta que essa sequência de granodecrescência ascendente encontra-se comumente interrompida, o que denotaria diversos ciclos de sedimentação deste sistema fluvial quaternário.

Takya (op. cit.) sugere duas fases principais de desenvolvimento de rios meandrantes para os depósitos aluviais quaternários de São Paulo, correlacionando-os à prováveis paleoclimas e paleovegetações vigentes (Figura 6). A primeira seria contemporânea ao último glacial (Würn) no intervalo de $32.480+/-330$ anos A.P. a $18.940+/-110$ anos A. P., e a segunda teria se iniciado provavelmente na passagem Pleistoceno/Holoceno até o estágio pré- 
perturbação das planícies fluviais paulistanas. A mesma autora identifica ainda que a partir de 6.000 anos A. P. teria se iniciado uma fase de sedimentação orgânica intensa.

Estudos nos sedimentos quaternários dos rios paulistanos indicam a ausência de falhamentos afetando estes depósitos (ALMEIDA et al., 1984, p. 1803; TAKIYA, 1997, 108).

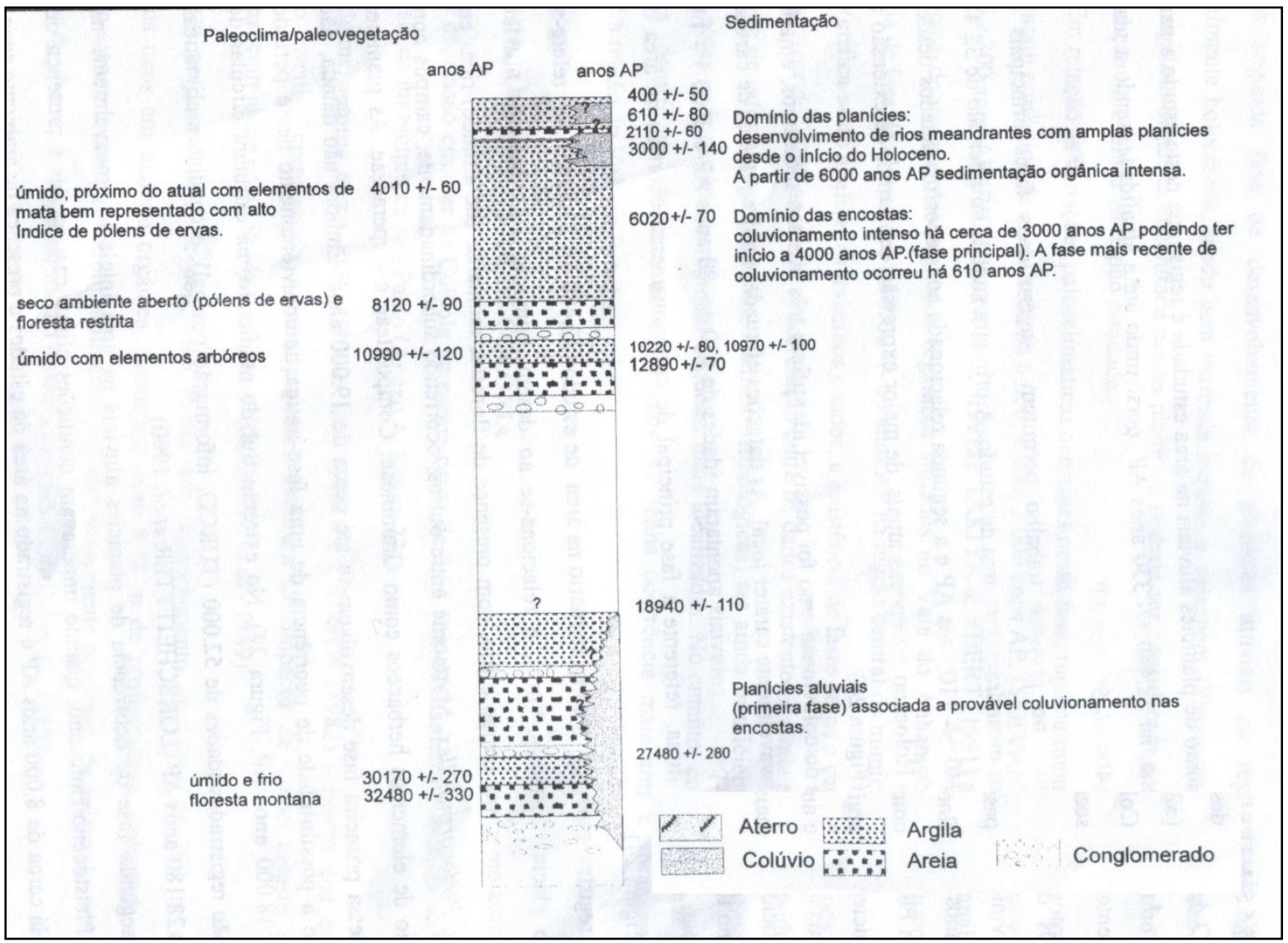

Figura 6 - Correlação entre a sedimentação quaternária no Município de São Paulo, idades, paleoclimas e paleovegetação segundo Takiya (1997).

A revisão da literatura a respeito do conhecimento sobre a geologia das planícies fluviais dos rios paulistanos mostra que estudos voltados especificamente às camadas mais superficiais da planície são os mais recentes, e foram realizados com maior detalhamento na planície do rio Tietê, faltando ainda um conhecimento mais detalhado na planície fluvial do rio Pinheiros. As características das formações sedimentares aqui revisitadas são retomadas adiante para a área de estudo. 


\subsection{GEOMORFOLOGIA}

A Figura 7 (Mapa Geomorfológico da RMSP) apresenta os dois grandes compartimentos do relevo da RMSP que condicionaram o modelado da região: os terrenos do embasamento pré-cambriano e os terrenos da Bacia de São Paulo (RODRIGUES, 2006).

\section{Embasamento pré-cambriano}

Terrenos pertencentes à unidade morfoestrutural do Cinturão Orogênico do Atlântico e à unidade morfoescultural do Planalto Atlântico (ALMEIDA, 1964; ROSS \& MOROZ, 1997). Na RMSP o Planalto Atlântico é subdividido em: Planalto Paulistano, que ocorre na maior parte da região; Serra da Cantareira, ao norte; Serraria de São Roque, a oeste; Serra do Mar e de Paranapiacaba, ao sul e; Planalto de Paraibuna a leste.

Estes planaltos e serras abrigam morros com vertentes de média a alta declividade e de topos convexos, serras alongadas, e pequenas planícies fluviais isoladas.

\section{Bacia de São Paulo}

Terrenos pertencentes à unidade morfoestrutural das Bacias Sedimentares Cenozóicas e à unidade morfoescultural do Planalto de São Paulo (ROSS \& MOROZ, op. cit.). Correspondem ao compartimento central da RMSP, sobre o qual a cidade de São Paulo teve seu núcleo inicial.

Abrigam colinas com vertentes de baixas declividades e topos aplanados e amplas planícies fluviais dos principais rios paulistanos (AB'SABER, 1957; ALMEIDA, op. cit.). Entre os topos regionais e os fundos de vale destes rios ocorrem patamares escalonados, que correspondem ao modelado típico da porção central da Bacia de São Paulo. Esta compartimentação geomorfológica é apresentada por Ab'Saber (op. cit.) (Figuras 8 e 9). 


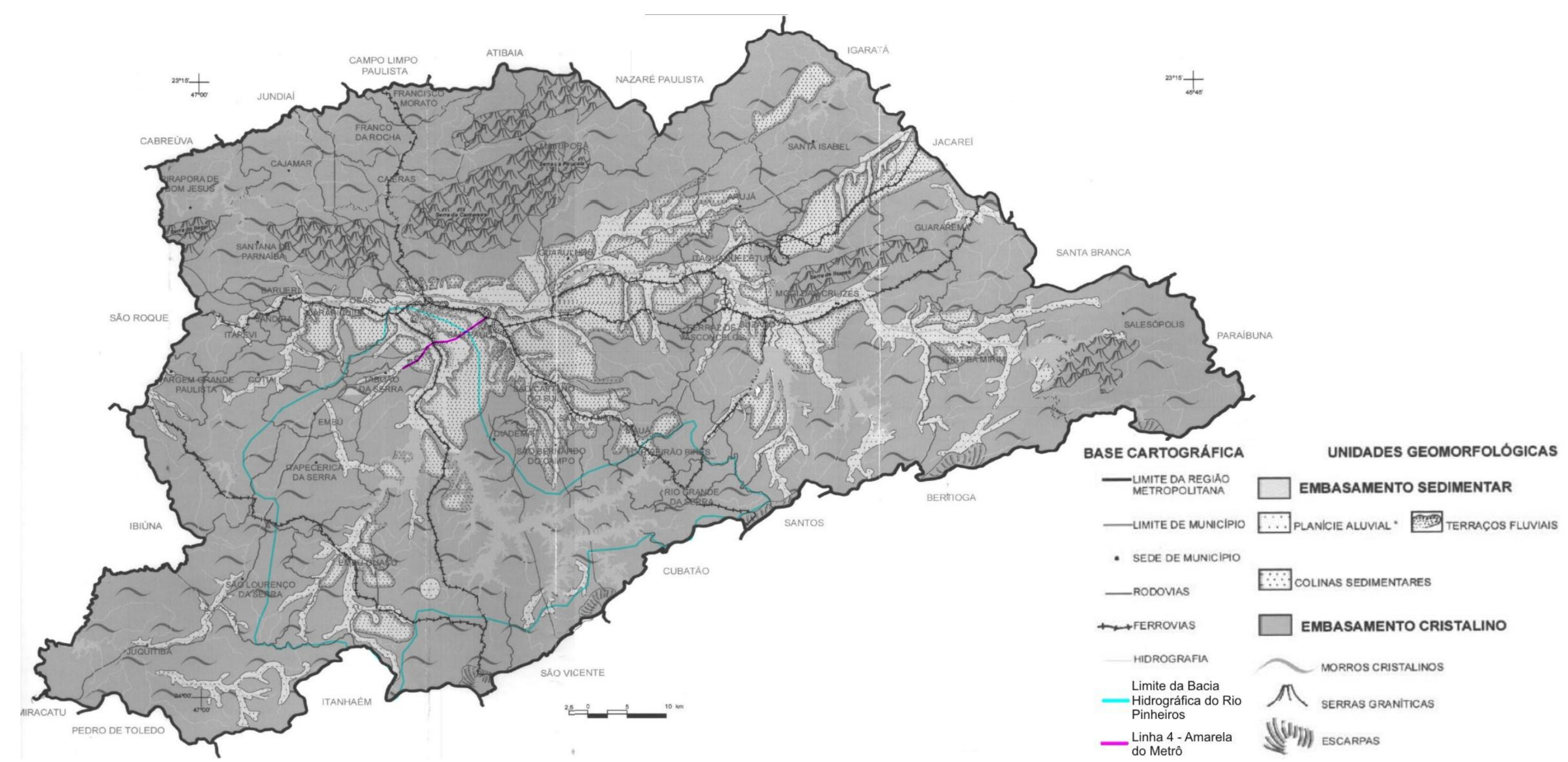

Figura 7 - Mapa geomorfológico da Região Metropolitana de São Paulo. Adaptado de Batista (2003) e Rodrigues (2006).

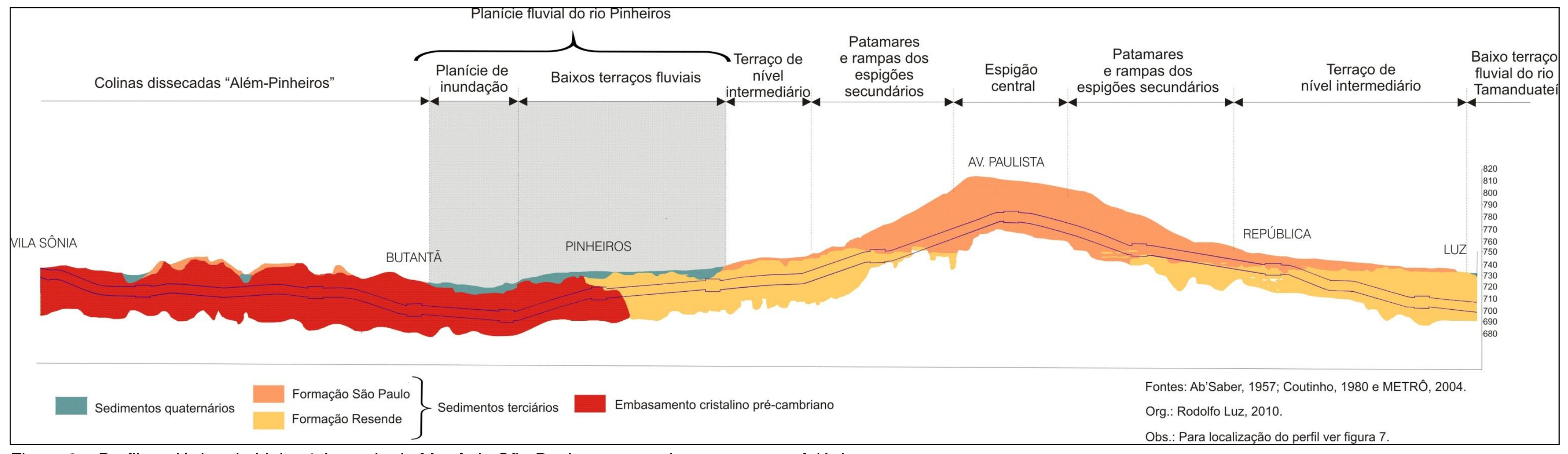

Figura 8 - Perfil geológico da Linha 4 Amarela do Metrô de São Paulo e compartimentos geomorfológicos. 


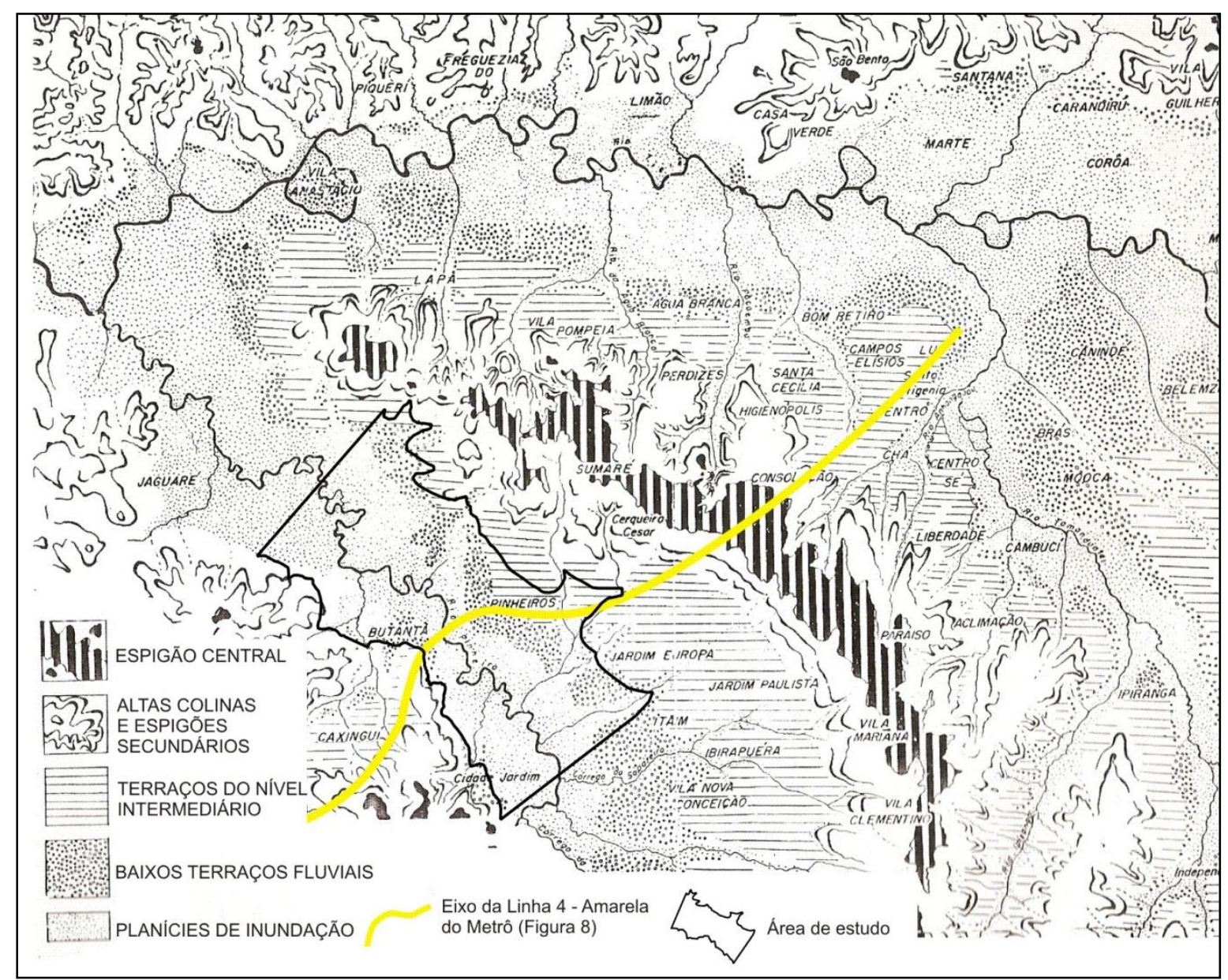

Figura 9 - Mapa geomorfológico de Ab'Saber (1957) com a localização da área de estudo e da Linha 4 do Metrô (conforme perfil geológico da figura 8).

A bacia hidrográfica do rio Pinheiros localiza-se no centro-sul da RMSP, sobre os dois compartimentos do relevo descritos.

Seus formadores têm origem nos contrafortes da Serra do Mar, e seguem preferencialmente na direção $\mathrm{L}-\mathrm{O}$ enquanto atravessam os terrenos do embasamento pré-cambriano. Próximo à Bacia Sedimentar de São Paulo mudam sua direção para SE-NO, até a região de Santo Amaro, onde os rios Grande e Guarapiranga unem-se e formam o Pinheiros. Neste local há outra mudança de direção, o rio inflecte cerca de $90^{\circ}$ até a região de Cidade Jardim, onde ele retoma novamente a direção SE-NO até a confluência com o rio Tietê.

Esta configuração da rede hidrográfica, com frequentes mudanças de direção, reflete as características tectônicas regionais e os compartimentos geomorfológicos associados, como pode ser visto em Ab'Saber (1957, p. 69-78), Almeida (1958, p. 155) e Santos (1958, p. 51),que mostram como a existência 
da Bacia Sedimentar de São Paulo influi diretamente na hidrografia regional, pois, ao adentrar nela os rios normalmente alteram a sua direção.

Além disso, inflexões na direção do rio Pinheiros onde já é formada sua ampla planície fluvial, entre Santo Amaro e sua confluência com o rio Tietê, podem refletir possíveis influências da estrutura geológica na configuração desta planície.

É em Ab'Saber (1957) que o relevo da planície fluvial do rio Pinheiros na área de estudo no estágio pré-perturbação é descrito de forma detalhada. $O$ autor identifica os seguintes compartimentos geomorfológicos (Figuras 8 e 9):

\section{Baixos terraços fluviais}

Nível localizado em altitudes entre 724 e 740 metros compondo a maior parte do terreno da planície na margem direita do rio. Na margem esquerda estes terraços ocorrem de forma mais restrita, já em contato com os sopés das colinas e morros dissecados sustentados pelo o embasamento pré-cambriano.

O limite superior dos baixos terraços fluviais é na maior parte das vezes com os terraços de nível intermediário, mas pode ser também com as altas colinas e espigões secundários, ambos sobre os sedimentos terciários da Bacia de São Paulo.

O limite inferior se dá com a planície de inundação, seja em forma de rebordos com terminação em rampas suaves, seja em "rebordos com terminação em pequenos taludes" (AB'SABER, op. cit., p. 141). Porém, após o aterramento da planície de inundação este limite se altera, pois os aterros são, em geral, nivelados em cotas próximas as dos baixos terraços, como é mostrado no mapeamento de Petrone (1963).

Dessa maneira, o nível topográfico dos baixos terraços fluviais hoje avança em direção ao canal do Pinheiros através de aterros, reduzindo assim a área da planície de inundação original e formando um "nível de terraços antrópicos" (AB'SABER, 1978, p. 18). Estes aterros formam os depósitos tecnogênicos que estão situados no topo da coluna estratigráfica de São Paulo e região (PELOGGIA, 1997). 
Ab'Saber (1953, p. 98-103 e 1957, p. 139-140) considera que a formação desses baixos terraços fluviais teria ocorrido no Pleistoceno e Almeida (1958, p. 164) afirma que dificilmente eles foram formados pelo rebaixamento do nível do mar provocado por mudanças climáticas relacionadas ao último máximo glacial (Würn).

O fato de parte da malha urbana da cidade e das grandes ferrovias terem se instalado preferencialmente nestes terraços tem dificultado as pesquisas de sua morfologia e estrutura desde a década de 1950 (AB'SABER, 1957, p. 141).

\section{$\underline{\text { Planície de Inundação }}$}

Segundo Ab'Saber (op. cit.) a planície de inundação do rio Pinheiros no estágio pré-perturbação localizava-se entre as cotas de 719 e 724 metros e estaria subdividida em duas:

a - Planície de inundação sujeita apenas às grandes cheias (entre $722 \mathrm{e}$ 724 metros). São alongadas e descontínuas faixas de terrenos aluviais mais enxutos e correspondem a diques marginais ou apresentam "a aparência de rasos terraços desprovidos de quaisquer taludes" (AB'SABER, op. cit., p. 148), decaindo em rampa quase imperceptível em direção às;

b - Planícies de inundação sujeitas a inundações anuais (entre 719 e 721 metros).

As principais morfologias que ocorreriam nestas planícies fluviais são citadas por Ab'Saber (op. cit., p. 150) e Bigarella (1971, p. 3-4), são elas: diques marginais, baixadas laterais (aqui entendidas como as bacias de inundação, ou "backswamps"), lagoas de meandros abandonados e feixes de restinga fluvial ribeirinhas (aqui entendidos como cordões marginais convexos). Entretanto, não há estudos que caracterizaram e mapearam estas feições geomorfológicas.

A revisão da literatura a respeito do conhecimento sobre a Geomorfologia das planícies fluviais dos rios paulistanos mostra que estas planícies foram objeto de estudo em pesquisas de escala de semi-detalhe, no qual o intuito principal era 0 
de compreender a compartimentação geomorfológica da cidade de São Paulo (AB'SABER, 1957) ou do bairro de Pinheiros (PETRONE, 1963).

Estes estudos identificaram diferentes níveis de terraços e de planícies de inundação (várzeas). Referências a algumas unidades morfológicas da planície de inundação foram realizadas (diques, backswamps, meandros abandonados, etc.), porém, sem a espacialização destas unidades em cartas de detalhe.

Segundo Ab'Saber (op. cit., p. 141), o desenvolvimento da área urbanizada sobre a planície fluvial do rio Pinheiros ocasiona uma verdadeira camuflagem da geomorfologia do sítio original. Porém, a aplicação da metodologia aqui proposta, que teve como objetivo caracterizar os estágios pré-perturbação dos sistemas geomorfológicos da área possibilitou este tipo de análise (RODRIGUES, 2004 e 2005). 


\section{METODOLOGIA}

\subsection{REFERENCIAL TEÓRICO-METODOLÓGICO}

A Geomorfologia tem como objeto de estudo as formas de relevo terrestre (CHRISTOFOLETTI, 1974, p. 1; MARQUES, 1994, p. 23), porém, a forma por si só, faz da Geomorfologia uma ciência de caráter meramente descritivo. Para ir além da descrição, a explicação das formas passa então pelo entendimento dos processos (HART, 1986, p. 88).

Soma-se a esses dois elementos (forma e processo) o estudo dos materiais que "cobrem a face da terra" (WHALLEY, 1990, p. 111), considerados como tudo aquilo que constitui a camada mais superficial da crosta terrestre, sustentando as formas que identificamos na paisagem (WHALLEY 1976; DACKOMBE \& GARDINER, 1983; VERSTAPPEN, 1983; HART, 1986). Estes são também designados como materiais superficiais, que podem conter ou não materiais pedológicos, sedimentos inconsolidados, rochas e materiais tecnogênicos.

Dessa maneira, o estudo da forma da superfície passa pelo entendimento dos processos responsáveis por ela e pela observação das propriedades dos materiais que a compõem.

Essa dependência teórica entre estes três elementos que permeia os estudos geomorfológicos já indica a preocupação com as relações dinâmicas entre diferentes variáveis como paradigma norteador da pesquisa. É dentro desse contexto que a abordagem sistêmica se mostra apropriada para 0 desenvolvimento da mesma, pois permite o entendimento dos fenômenos naturais de forma integrada (TRICART, 1977, p. 19; RODRIGUES, 2001a).

O reconhecimento dos fenômenos geomorfológicos é realizado, muitas vezes, pela sua espacialização, que é representada por mapas. Nos mapas geomorfológicos são demarcadas principalmente as formas do terreno, porém, faz-se necessário também demarcar os materiais superficiais, os processos (morfodinâmica) e a cronologia das formas (morfogênese) (COLTRINARI, 1984; HART, 1986, p. 183). 
O nível interpretativo da pesquisa foi alcançado a partir das correlações espaciais de alguns parâmetros dos três níveis da investigação geomorfológica (formas, materiais e processos). Esses parâmetros são representados no mapa geomorfológico e serão apresentados a seguir.

\subsubsection{Mapeamento Geomorfológico}

O mapa geomorfológico torna-se um dos principais instrumentos de análise da pesquisa geomorfológica quando concebido nos moldes das "Cartas Geomorfológicas de Detalhe" conforme Tricart (1965) e Coltrinari, (1982 e 1984). Estas, "são cartas temáticas que fornecem uma descrição completa de todos os elementos do relevo e do modelado da região a que se referem" (COLTRINARI, 1984, p. 96). Assim, o mapa não se configura como uma tradução gráfica de uma análise geomorfológica, mas sim como a base desta análise, onde são compreendidas as relações espaciais por meio dos compartimentos geográficos identificados. Isso faz com que este tipo de carta tenha um valor analítico intrínseco constituindo o objetivo da investigação geomorfológica, confundindo-se, inclusive, com seu próprio objeto de estudo, já que auxilia no entendimento genético, dinâmico e espacial das formas da superfície (TRICART, op. cit., p. 183-184; RODRIGUES, 1997a, p. 88).

As cartas geomorfológicas de detalhe devem conter informações a respeito da:

- Morfometria (dimensões da forma e dos materiais superficiais);

- Morfografia (forma real de cada feição da superfície terrestre);

- Morfodinâmica (processos responsáveis pela configuração atual da paisagem) e;

- Cronologia das formas (fase morfogenética da forma).

Porém, nem sempre estes níveis de informações são satisfatoriamente alcançados devido à carência de estudos de geomorfologia tropical (COLTRINARI, 1982, p. 60).

O grau de padronização e o grau de uniformização das unidades de mapeamento dependem da escala espacial da área mapeada. No caso da 
Geomorfologia, a escala define a categoria de fenômenos que será mapeada em primeiro plano, se aqueles relativos ao relevo ou aqueles relativos ao modelado, que direcionam a confecção dos mapas geomorfológicos conforme a escala (TRICART, 1965; COLTRINARI, 1982, p. 55):

- Cartas geomorfológicas de pequena escala (1:500.000 e menores) utilizadas para a cartografação dos conjuntos de relevo de dimensões quilométricas, onde os aspectos estruturais são mais representativos e;

- Cartas de detalhe (1:5.000 a 1:25.000) e semi-detalhe $(1: 50.000$ e 1:100.000) utilizadas para a cartografação do modelado.

Esta sistematização direciona o mapeamento geomorfológico aplicado na pesquisa, que trata de uma carta de detalhe na escala de 1:20.000 que apresenta as formas da planície fluvial do rio Pinheiros no estágio préperturbação antrópica, bem como os materiais superficiais e os processos geomorfológicos associados a essas formas.

\subsubsection{Geomorfologia Fluvial}

Sendo esta pesquisa direcionada a sistemas geomorfológicos fluviais, como planícies de inundação, canais, terraços, etc. torna-se necessário apresentar os principais conceitos e parâmetros desse ramo da investigação geomorfológica e que são aqui utilizados.

A Geomorfologia Fluvial interessa-se pelos processos, formas e materiais relacionados ao escoamento dos rios, englobando assim estudos dos cursos de água e das bacias hidrográficas (CHRISTOFOLETTI, 1974, p. 52; CUNHA, 1994, p. 211).

Miall (1978, p. 11), enumera os seguintes tópicos como essenciais nos estudos sedimentológicos e geomorfológicos relacionados aos ambientes fluviais:

- Geomorfologia fluvial descritiva: trata das características físicas dos sistemas fluviais, sua evolução e variação da nascente até a foz; 
- Geomorfologia fluvial quantitativa: estudos sobre a geometria hidráulica (largura, profundidade, declividade, descarga, sinuosidade e carga sedimentar);

- Estudos de transporte de sedimentos: taxa de transporte e mudanças texturais a jusante;

- Estudos sobre as formas do leito: profundidade de canal, velocidade de fluxo e tamanho da partícula;

- Estudos faciológicos: reconhecimento dos vários componentes litológicos de um depósito fluvial, propiciando a generalização em forma de modelos faciológicos e;

- Estudos paleohidráulicos: tratam das relações quantitativas entre os parâmetros hidráulicos de um rio e seus depósitos mais preservados. Através da reconstrução paleohidrológica é possível identificar os tipos de canais que criaram os depósitos analisados (RICHARDS, 1985, p. 5).

Considerando essa sistematização, a presente pesquisa está vinculada principalmente ao tema dos estudos de geomorfologia fluvial descritiva, mas insere-se também em parte dos estudos de geomorfologia fluvial quantitativa, de estudos paleohidráulicos e de estudos faciológicos.

A classificação de padrões de drenagem, bastante enraizada na literatura geomorfológica, foi apresentada por Leopold et al. (1964, p. 281-332) e separou os rios em três tipos básicos de canais: retilíneo, meândrico e entrelaçado (braided). Há também o padrão anastomosado (anastomosing), que é semelhante ao entrelaçado, porém com margens estáveis e predomínio de carga em suspensão (MORISAWA, op. cit., p. 91; KNIGHTON, 1998, p. 207). Knighton (op. cit., p. 207) destaca que, apesar da variedade dos padrões agora conhecidos, a original subdivisão permanece relevante devido a sua associação com o conceito continuum introduzido por Leopold et al. (op. cit.).

Tendo em vista a grande variedade de classificações de canais e sistemas fluviais existentes, Stevaux (1993, p. 32) afirma que as dificuldades de aplicação destas diversas sistematizações fizeram com que restassem, na 
prática, a divisão apenas entre os sistemas meândricos, entrelaçados e, mais recentemente, os anastomosados. Desde então, estes tipos de canais e sistemas deposicionais associados foram os que mais mereceram atenção dos pesquisadores, demonstrando que há uma evidente correlação entre a morfologia fluvial (forma) e os sedimentos que a compõem (materiais) que, por sua vez, resultam dos processos que atuam, ou que já atuaram, no sistema (Figura 10).

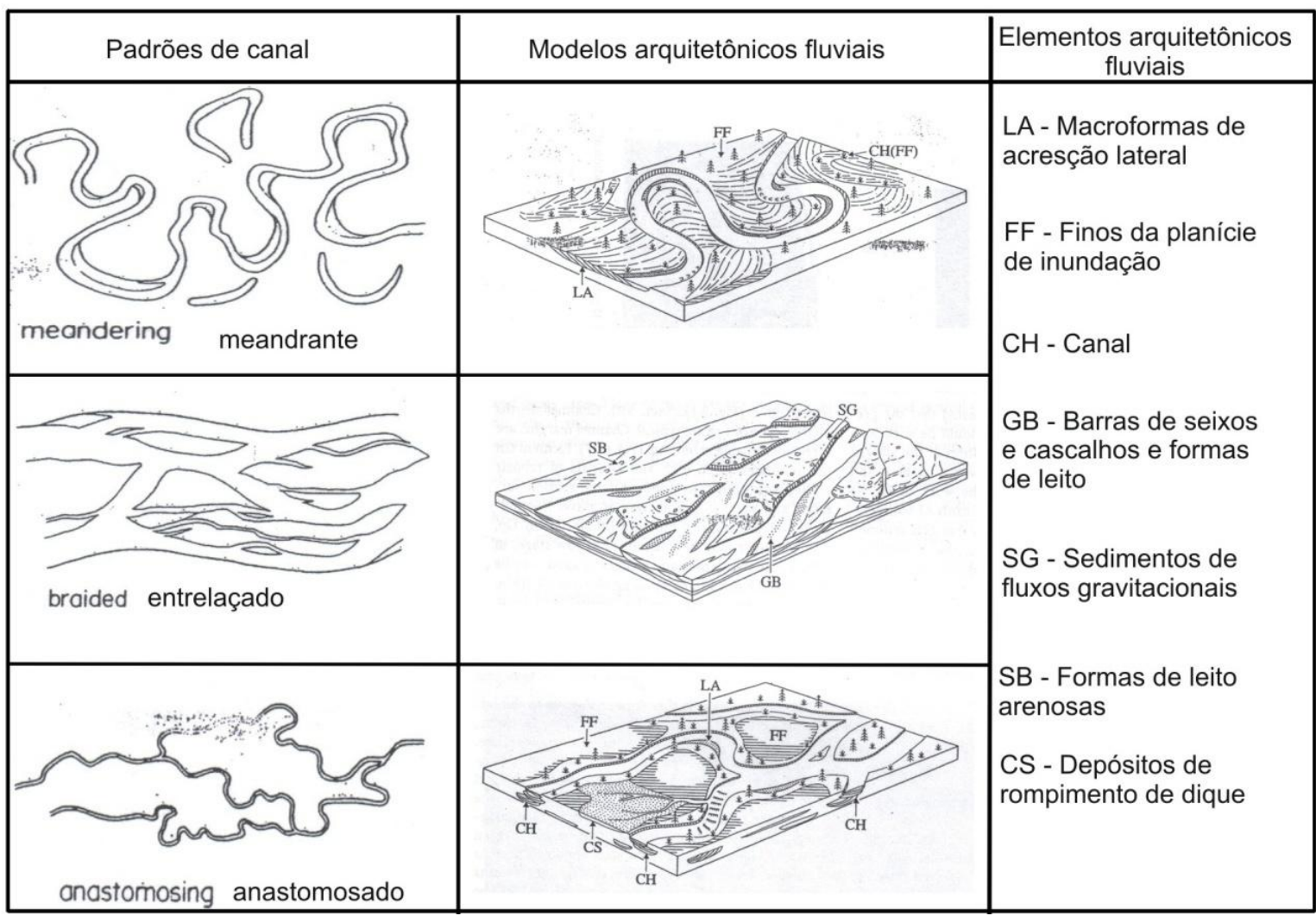

Figura 40 - Padrões de canal e sistemas deposicionais associados. Modificado de Miall (1996).

\subsubsection{Sistemas Meândricos}

O rio Pinheiros em seu estágio pré-perturbação era meandrante, de forma que se faz necessário apresentar alguns conceitos-chave relativos aos sistemas fluviais meândricos a fim de se ter clareza quando da apresentação dos resultados da pesquisa.

A maior parte dos sedimentos depositados neste tipo de sistema é oriunda da migração lateral do canal fluvial (Figura 11A) e o depósito resultante tem como característica básica a granodecrescência ascendente (Figura 11B). Dessa 
forma, cada pacote que representa a granodecrescência ascendente pode ser considerado como um ciclo de deposição meândrico, resultado da migração lateral do canal e subsequente formação da planície de inundação, até que o canal retorna a este ponto e dá início a um novo ciclo de deposição (nos casos onde a planície de inundação passa por um processo de acumulação vertical).

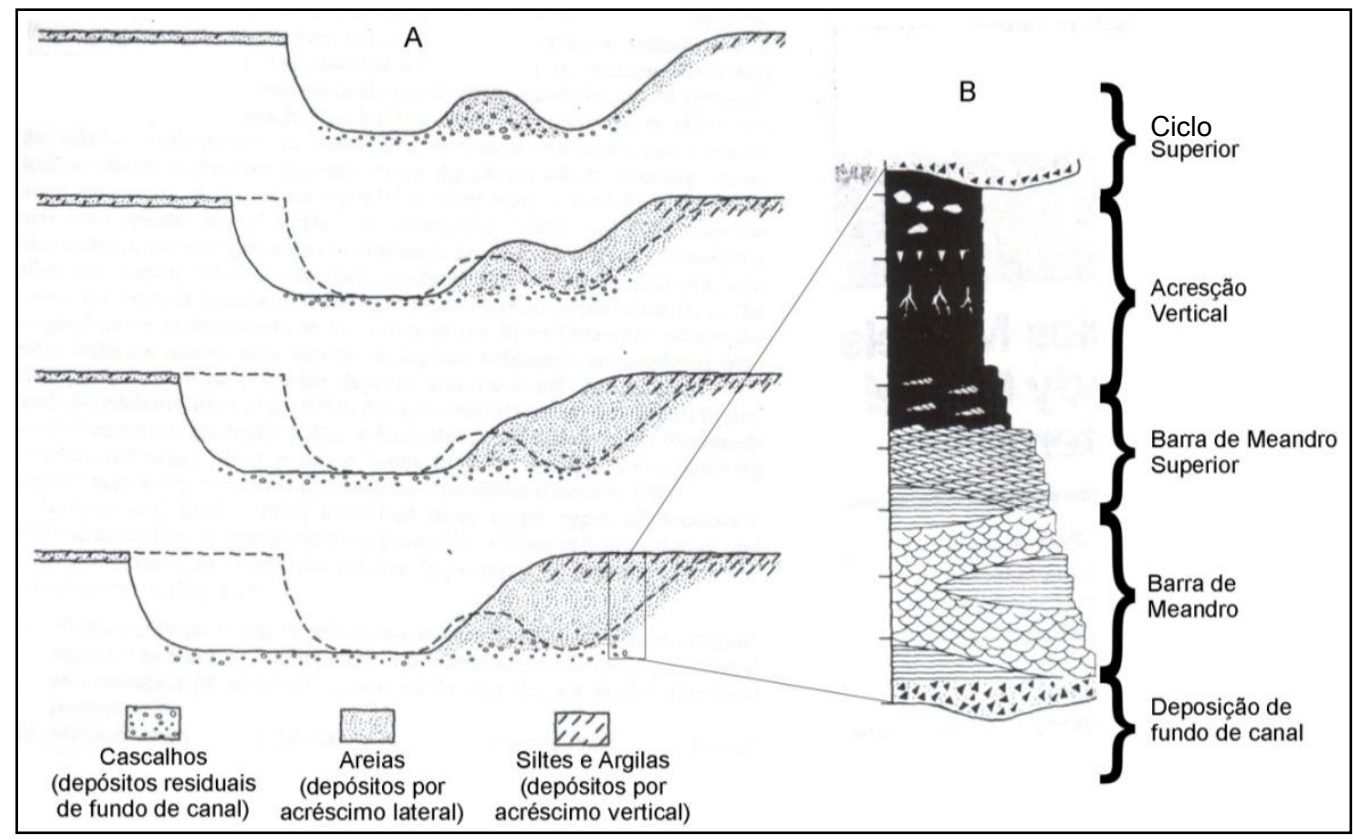

Figura 11 - Migração lateral em sistemas meândricos e faciologia resultante. A) Diagrama representando a construção progressiva de uma planície de inundação, modificado de Knighton (1998). B) Modelo faciológico de deposição de rios meandrantes, modificado de Walker (1983).

O mapeamento geomorfológico da planície fluvial do rio Pinheiros tem como base os três subsistemas fluviais típicos de um sistema meândrico, conforme Leopold et al. (1964, p. 317), Tricart (1966), Christofoletti (1974 e 1981) e Bridge (2003) (Figuras 12 e 13):

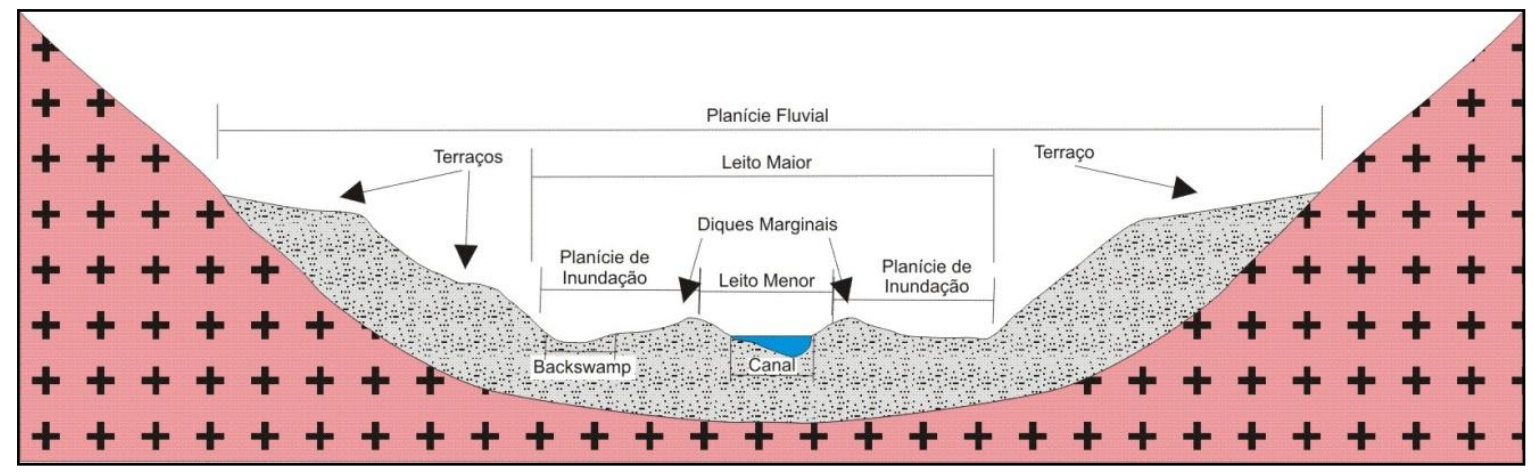

Figura 12 - Croqui esquemático de uma planície fluvial com os subsistemas e formas associadas. Org.: Rodolfo Luz. 


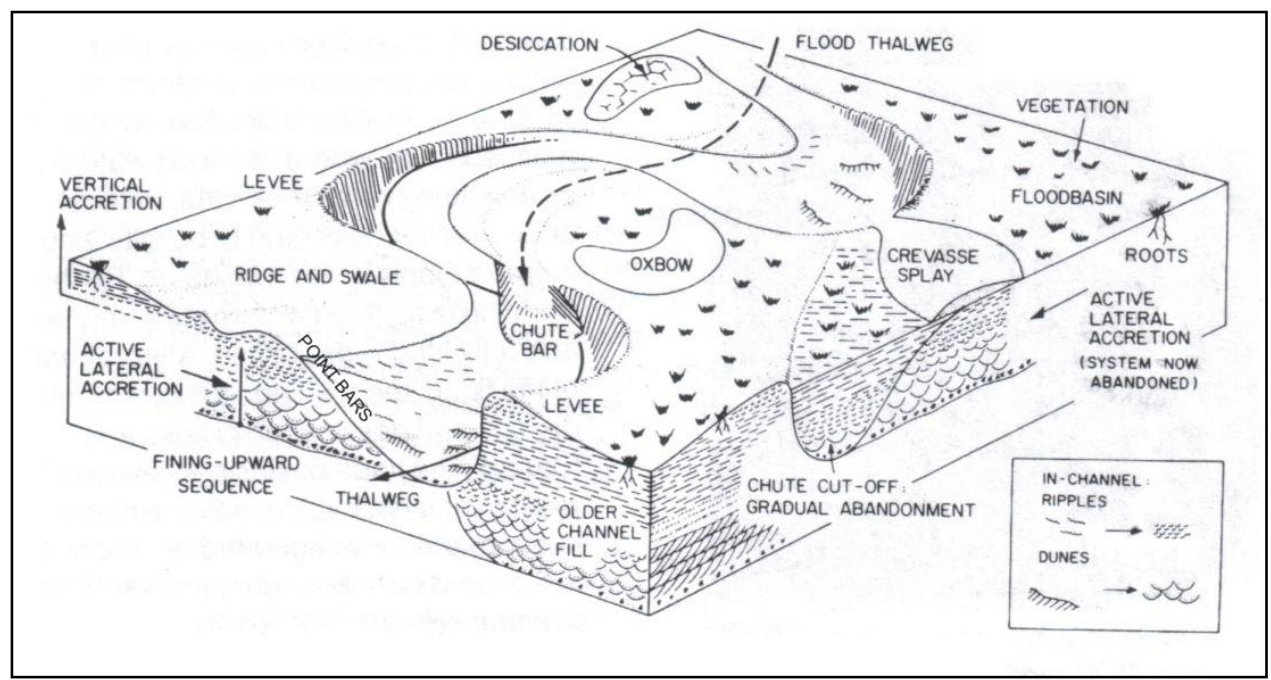

Figura 13 - Bloco diagrama mostrando os principais elementos morfológicos dos sistemas meândricos. Modificado de Walker (1983).

\section{$\left.\underline{\text { Subsistema do canal fluvial }}\right|^{2}$}

Corresponde ao leito menor da planície, zona que contem os caudais habituais do rio. É onde ocorre a vazão de margens plenas (vazão que preenche o leito menor do canal fluvial, acima da qual ocorrerá o transbordamento para a planície de inundação). Apresenta as seguintes unidades morfológicas:

- Canal ativo: que em sistemas meândricos possuem uma seção transversal assimétrica em seus trechos curvos, com uma margem côncava e profunda onde o fluxo é mais rápido e uma margem convexa e rasa onde o fluxo é mais lento.

- Meandros ou canais abandonados (oxbow): que representa os trechos abandonados das curvas meândricas que, ao serem separados do canal ativo do rio, passam a sofrer processos de colmatação. O grau de colmatação destes meandros pode representar a escala evolutiva dos abandonos (SANTANA, 2008, p. 45) que pode ocorrer de três maneiras (Figura 14): 1) pelo encurtamento do meandro; 2) pela separação do meandro em função do corte do pedúnculo (cutoff) e; 3) pelo

\footnotetext{
${ }^{2}$ Optou-se por utilizar o termo "canal fluvial" para diferenciá-lo da terminologia "canal", que muitas vezes se refere a canais artificializados, como é o caso do canal do Pinheiros, conforme terminologia adotada pela Empresa Metropolitana de Águas e Energia S. A. (EMAE) (fonte: www.emae.sp.gov.br/ canais.htm).
} 
deslocamento súbito de uma parte ou conjunto do canal meândrico (avulsão) (CHRISTOFOLETTI, 1981, p. 233).

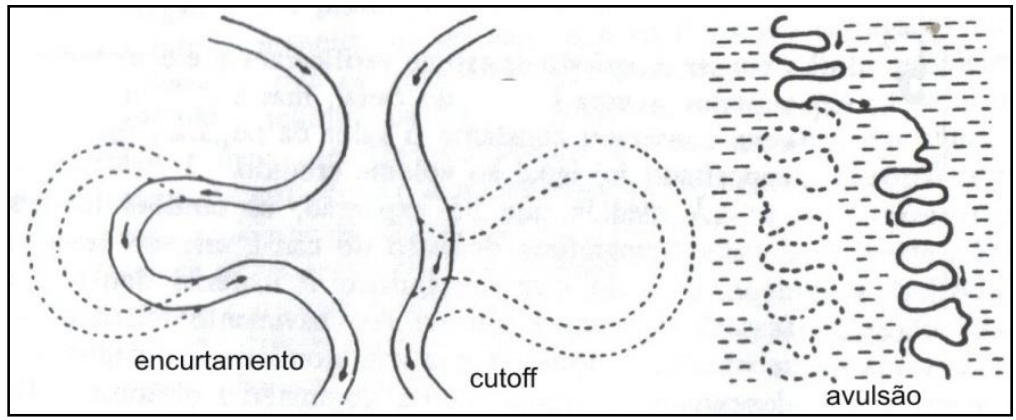

Figura 14 - Tipos de abandonos de canal em sistemas meândricos. Modificado de Christofoletti (1981).

- Barras de acresção lateral (point bars): ambiente de deposição nas margens convexas dos canais ativos, compostas por sedimentos grosseiros (principalmente areais) depositados numa primeira etapa de sedimentação recobertos por sedimentos mais finos depositados numa segunda etapa de evolução por correntes secundárias (NANSON, 1980, p. 24) (Figura 15);

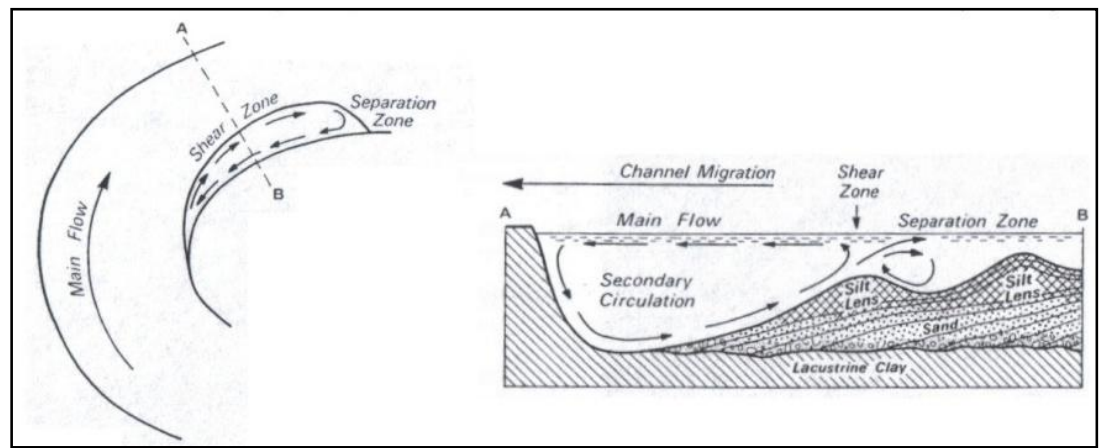

Figura 15 - Sedimentação de uma barra de acresção. Formação de uma zona de separação adjacente à margem convexa e deposição de finos. Modificado de Nanson (1980).

\section{Subsistema da planície de inundação}

Corresponde ao leito maior, que é regularmente ocupado pelas cheias. A vazão de margens plenas demarca a descontinuidade entre este subsistema e o do canal fluvial. Em sua maior parte, é formada por sedimentos grossos advindos da movimentação lateral do canal fluvial, cobertos por sedimentos finos advindos da carga suspensa das águas de cheia (MACKIN, 1937 apud LEOPOLD et al., 1964, p. 323). Apresenta as seguintes unidades morfológicas: 
- Cordões marginais convexos ou arco meândrico (meander scrolls ou ridge-swale): saliências e depressões nas margens convexa das curvas meândricas formados à medida que o canal fluvial migra lateralmente em direção a margem côncava, devido à acresção lateral;

- Diques marginais (levee): cristas ou saliências formadas acima da superfície da planície de inundação e adjacentes ao canal fluvial, geralmente contendo material de maior granulometria depositado durante as fases de transbordamento;

- Bacias de inundação (backswamp ou floodbasin): terrenos baixos localizados entre os diques marginais e os terraços ou vertentes onde predominam depósitos de sedimentos finos;

- Depósitos de rompimento de dique (crevasse splay): depósitos formados durante as cheias a partir do rompimento dos diques marginais.

\section{Subsistema dos terraços fluviais}

Constituem planos horizontais ou subhorizontais topograficamente mais altos que a planície de inundação, onde as águas de inundação raramente alcançam. Pode ser definido como antigas planícies de inundação que foram abandonadas, sendo composto então pelos materiais sedimentares típicos destas planícies (LEOPOLD et al., 1964, p. 459).

Fundamentalmente, a formação de terraços ocorre por dois tipos de controles, que podem atuar de maneira individual ou conjunta (RICHARDS, 1985, p. 275): 1) mudanças no nível de base relativo ${ }^{3}$; 2 ) variações na vazão e na carga sedimentar imposta pela bacia hidrográfica. Estes controles podem ser resultados tanto de mudanças climáticas quanto de alterações tectônicas, e geram sequências evolutivas que possibilitam arranjos diversos entre os terraços (CHRISTOFOLETTI, 1981, p 255-258).

\footnotetext{
${ }^{3}$ Nível de base , no caso dos rios, é considerado o nível máximo onde um canal pode ser efetivamente erosivo, controlando toda dinâmica erosiva e sedimentar que ocorre a montante deste nível, ou seja, o ponto limite abaixo do qual a erosão das águas correntes não pode trabalhar (GUERRA, 1980, p. 303; GOUDIE, 2006, p. 62; OSTERKAMP, 2008, p. 8).
} 
O mapeamento destas unidades morfológicas de cada subsistema fluvial meândrico gera informações que podem ser aproveitadas por estudos de geomorfologia fluvial quantitativa como, por exemplo, os parâmetros geométricos dos canais meândricos (Figura 16).

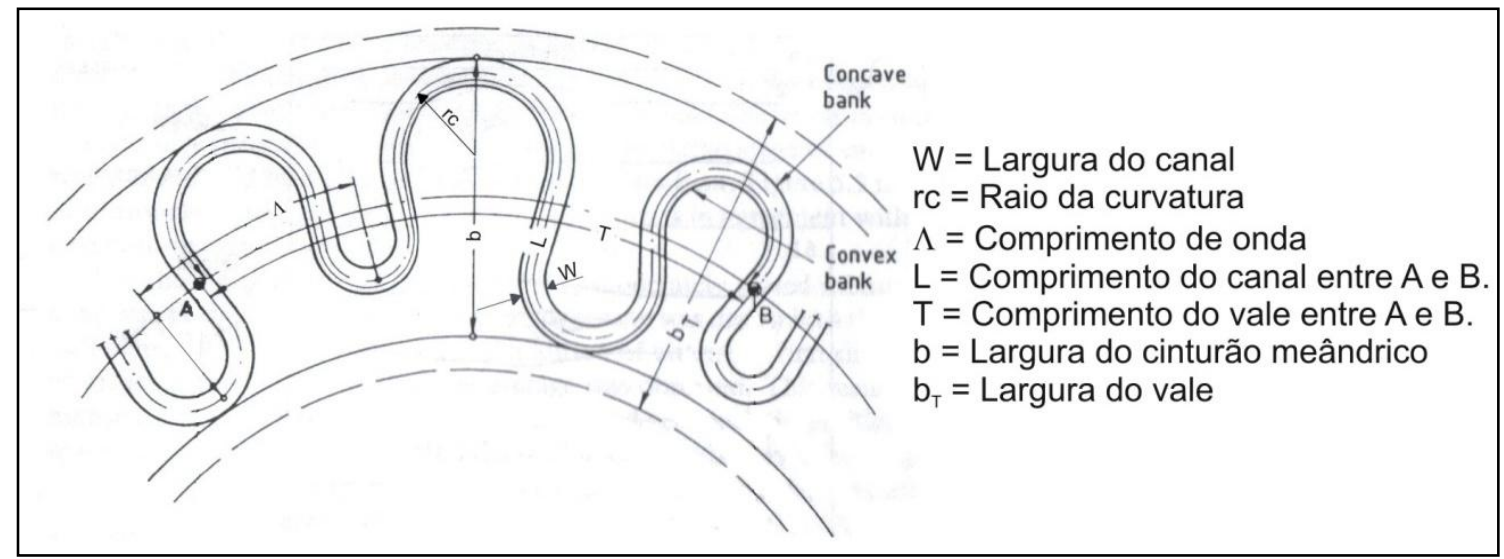

Figura 16 - Principais parâmetros geométricos de um canal meândrico. Modificado de Christofoletti (1974) e Mangelsdorf et al. (1990).

Uma das aplicações possíveis deste tipo de parâmetro, e que foi explorada na presente pesquisa, é a que se utiliza dos aspectos geométricos de meandros abandonados para interpretações cronológicas e paleoambientais (CHRISTOFOLETTI, 1974, p. 73).

Dentre estes parâmetros foi utilizado na pesquisa a largura do canal (w) e o índice de sinuosidade (Is), que é a relação entre o comprimento do canal e o comprimento do eixo do vale (Equação 1).

$$
I s=
$$

Tendo em vista que: 1) a sinuosidade do canal pode ser reflexo tanto do tipo de carga sedimentar (SCHUMM, 1963) quanto de movimentos tectônicos e controles litológicos, e que; 2) a área de estudo possui um contexto tectônico regional importante; entende-se que a tectônica pode ser um elemento explicativo na interpretação morfogenética da planície fluvial meândrica do rio Pinheiros quando baseada em diferenças entre os parâmetros geométricos de canais ativos e abandonados.

Estudos experimentais de laboratório realizados com o objetivo de verificar a influência de movimentações tectônicas lentas, ou de ocorrências de litologias mais resistentes dentro de uma planície fluvial meândrica indicam algumas 
tendências de transformações no sistema, como pode ser visto em Ouchi (1985) e Shumm et al. (2002) (Figura 17).

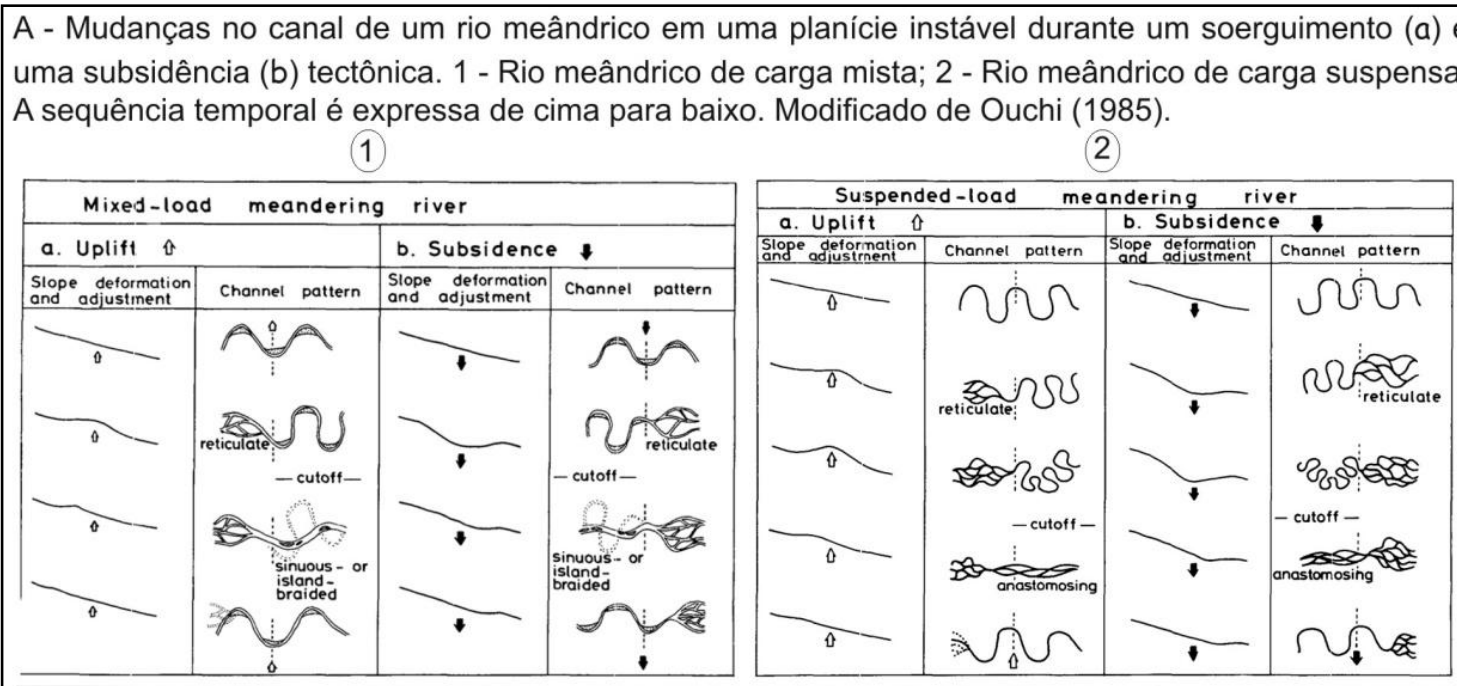

B - Mudanças no canal de um rio meândrico em uma planície estável após um soerguimento. Modificado de Schumm et al. (1987).

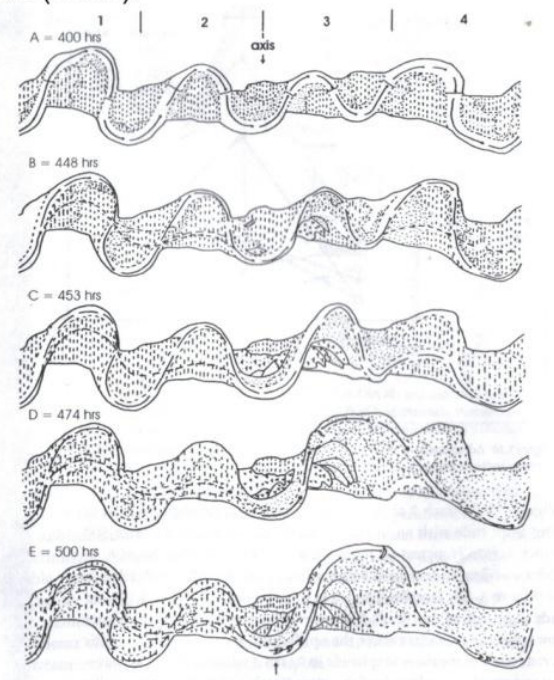

C - Modificações num canal meândrico submetido à um bloco de maior resistência (clay plug). Modificado de Schumm et al. (1987).

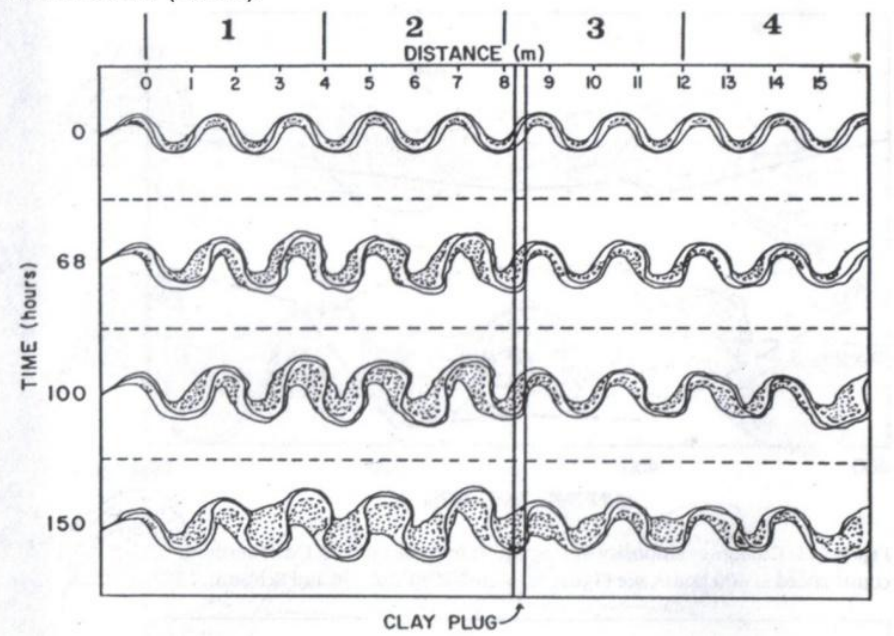

Figura 17 - Experimentos de laboratório que mostram a influência da estrutura geológica (tectônica e litologia) em canais meândricos. 


\subsection{PROCEDIMENTOS}

As etapas da pesquisa podem ser visualizadas no fluxograma abaixo, e foram divididas em levantamento dos dados, sistematização e análise:

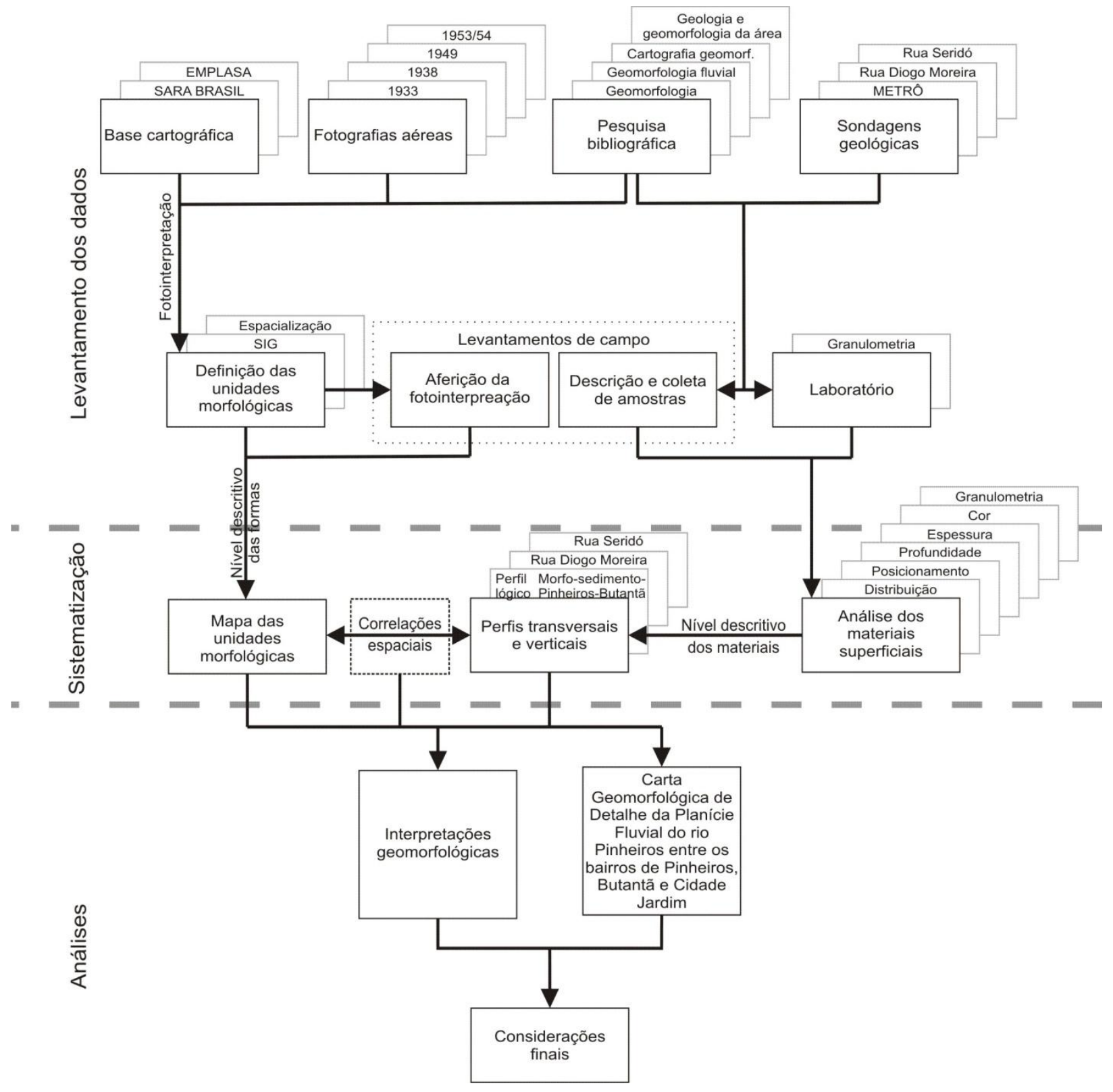

\subsubsection{Levantamento dos dados}

\subsubsection{Dados cartográficos}

A escala adotada (1:20.000), além de enquadrar-se no objetivo do estudo, foi condizente ao material aerofotográfico existente e consultado. A principal fonte cartográfica utilizada para os mapeamentos foram as plantas elaboradas pela 
empresa SARA BRASIL S/A (1930) na escala de 1:20.000, onde foi obtida a base cartográfica da região antes da retificação do canal fluvial e do aterramento da planície de inundação do rio Pinheiros. Essas plantas foram adquiridas no Laboratório de Aerofogeografia e Sensoriamento Remoto (LASERE) do Departamento de Geografia (FFLCH-USP).

Mapeamentos realizados pelo Governo do Estado de São Paulo através da Empresa Paulista de Planejamento Metropolitano (EMPLASA) nas escalas de $1: 2.000,1: 10.000$ e 1:25.000, das décadas de 1970 e 1980 e que formam parte do Sistema Cartográfico Metropolitano foram consultados quando houve necessidade de um maior detalhamento. Apesar desses mapeamentos serem relativos a momentos de pós-perturbação eles auxiliaram na resolução de dúvidas em setores localizados da área. Estas cartas foram adquiridas na mapoteca do Departamento de Geografia (FFLCH-USP) e nos acervos da Empresa Paulista de Planejamento Metropolitano S/A (EMPLASA).

Para a produção da carta geomorfológica de detalhe foram utilizadas aerofotos em escalas de 1:5.000, 1:12.500 e 1:25.000, obtidas em arquivos históricos sistematizados pelas pesquisas arquivísticas de Rodrigues (2001b) e Carvalho (2006) e adquiridas na Fundação Energia e Saneamento. O Quadro 1 e a Figura 18 apresentam estas aerofotos.

Quadro 1: Fotografias aéreas utilizadas.

\begin{tabular}{|c|c|c|c|c|c|}
\hline Data & Levantamento & Escala & Faixa / Região & $\begin{array}{c}\text { № das } \\
\text { fotografias }\end{array}$ & Fonte \\
\hline 1933 & Serviço 62. & $1: 5.000$ & $\begin{array}{l}\text { Rio Pinheiros e } \\
\text { bairros } \\
\text { adjacentes. }\end{array}$ & $\begin{array}{l}35785 a \\
35787 \text { e } \\
35794 a \\
35810 .\end{array}$ & $\begin{array}{l}\text { Fundação } \\
\text { Energia e } \\
\text { Saneamento }\end{array}$ \\
\hline 1938 & Serviço 58. & $1: 5.000$ & $\begin{array}{l}\text { Região da } \\
\text { Praça } \\
\text { Panamericana. }\end{array}$ & $\begin{array}{l}142,143, \\
145,146 \mathrm{e} \\
188\end{array}$ & $\begin{array}{l}\text { Fundação } \\
\text { Energia e } \\
\text { Saneamento }\end{array}$ \\
\hline 1949 & Serviço 62. & $1: 12.500$ & $\begin{array}{l}\text { Rio Pinheiros e } \\
\text { bairros } \\
\text { adjacentes. }\end{array}$ & $\begin{array}{l}06 \text { a } 20,31, \\
38,59 \text { e } 60\end{array}$ & $\begin{array}{l}\text { Fundação } \\
\text { Energia e } \\
\text { Saneamento }\end{array}$ \\
\hline 1953/54 & $\begin{array}{l}\text { Cidade de São } \\
\text { Paulo }\end{array}$ & 1:25.000 & Faixas 3,4 e 5 & $\begin{array}{l}55,68,70, \\
95 .\end{array}$ & $\begin{array}{l}\text { Arquivo de } \\
\text { Fotografias } \\
\text { Aéreas do Dep. } \\
\text { de Geografia da } \\
\text { USP (AFA-USP) }\end{array}$ \\
\hline
\end{tabular}


Por se tratar de um mapeamento restrito ao sistema fluvial, foram buscadas referências aos elementos fluviais em legendas dos seguintes estudos: Savigear (1965), Tricart (1965), Coutard et al. (1978), Dackombe \& Gardiner (1983), Hart (1986), Lima (1990) e Estaiano (2007).

Entretanto, devido à escala adotada, o maior detalhamento da morfologia fluvial e de sua representação foi orientado pelo estudo de Santana (2008), do qual foi baseada a maior parte da legenda utilizada. Além disto, este estudo também orientou algumas das interpretações morfogenéticas aqui apresentadas, pois ele é voltado à representação cartográfica da hidrodinâmica das inundações por tipo de evento e, realiza correlações espaciais entre os materiais pedológicos e sedimentológicos de um setor de uma planície fluvial meândrica do rio Ribeira de Iguape.

A restituição morfológica foi feita com estereoscópios de bolso e de espelho sobre as aerofotos. O principal levantamento utilizado foi o de 1933, por ser 0 de maior escala e o mais antigo, onde a morfologia pré-perturbação é mais evidente, além de apresentar sobreposição adequada para a montagem de pares estereoscópicos. As aerofotos restantes foram utilizadas apenas para resolução de dúvidas localizadas e para a restituição morfológica de unidades maiores, como os terraços.

Trabalhos de campo foram realizados para aferir e sistematizar as informações obtidas pela fotointerpretação. Devido ao caráter retrospectivo do mapeamento a maior parte da morfologia da área encontra-se significativamente modificada em relação àquela observada nas fotografias de 1933 e 1938. Portanto, os trabalhos possibilitaram apenas a identificação de limites e morfologias dos terraços fluviais, pois os elementos que ocorriam na planície de inundação e no canal do rio já se encontram modificados e aterrados. Nesta etapa foi possível verificar, mesmo que em caráter incipiente, o grau de modificação antrópica ocorrido na planície fluvial. 


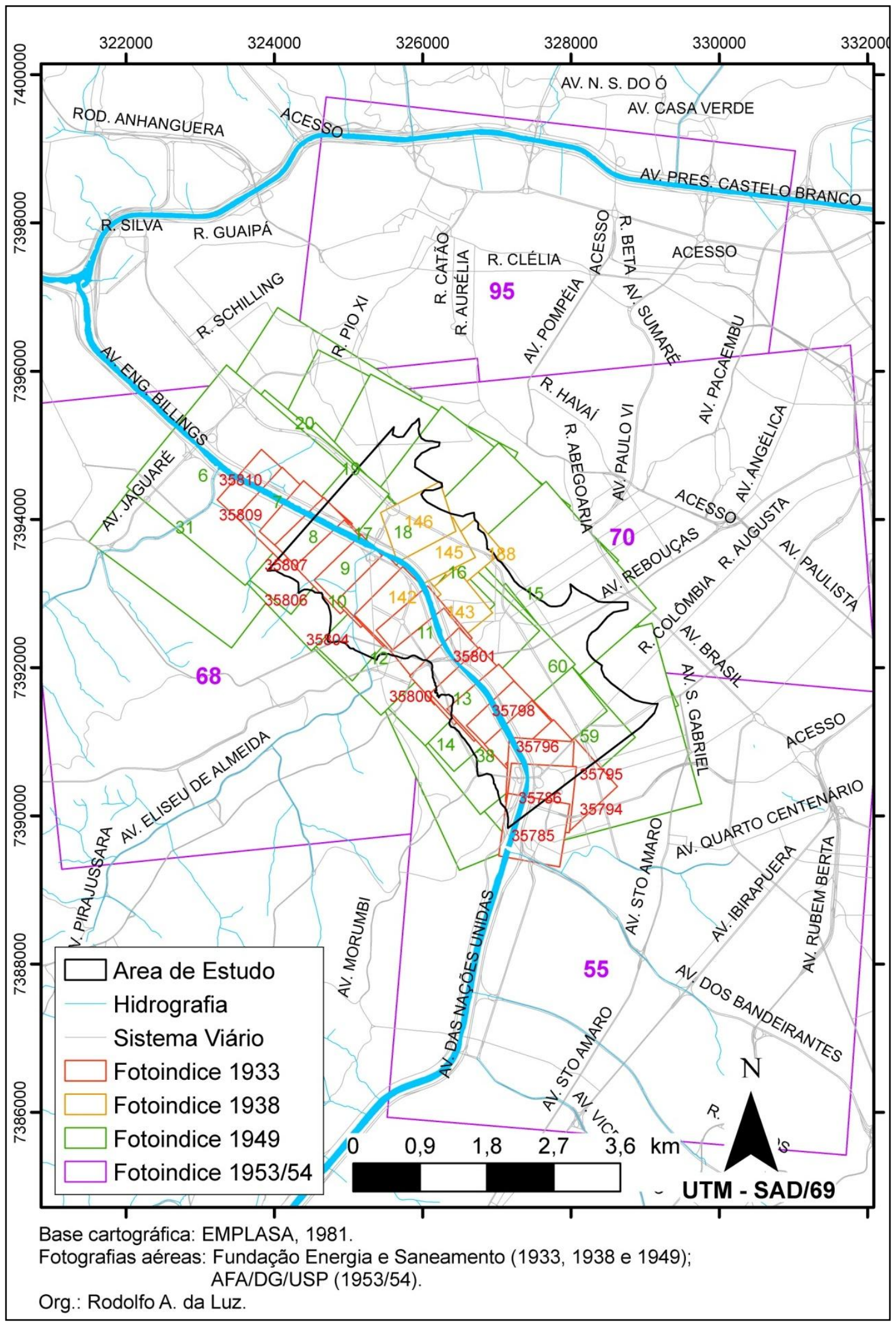

Figura 18 - Mapa-índice das fotografias aéreas utilizadas 


\subsubsection{Dados sobre os materiais superficiais}

A análise dos materiais superficiais foi realizada tendo como base Suguio (1973 e 2003); Lemos \& Santos (1982); Miall (1982 e 1996); Walker (1983) e; Whalley (1990).

A descrição das propriedades básicas dos materiais superficiais é considerada o ponto de partida para a explicação do processo geomorfológico (WHALLEY, op. cit., p. 112). Porém, a qualidade e validade destas descrições dependem da quantidade e distribuição espacial das amostras, além dos procedimentos utilizados para a sua obtenção.

As principais fontes de informação utilizadas na análise dos materiais superficiais foram as sondagens geológicas executadas por obras de engenharia, que foram complementadas por alguns levantamentos de campo em escavações de obras atuais.

Aqui, faz-se necessário o esclarecimento dos problemas e das potencialidades do uso de informações das sondagens geológicas em estudos geomorfológicos. Tendo em vista que o grau de detalhamento necessário para a caracterização dos materiais superficiais em pesquisas geomorfológicas é diferente do apresentado pelas sondagens geológicas, existem algumas deficiências intrínsecas ao próprio procedimento técnico. Essas deficiências são decorrentes das diferenças entre as escalas de análise e entre as terminologias de cada um dos tipos de investigação:

- A primeira deficiência é com relação à representatividade espacial da informação, já que os furos de sondagem utilizados possuem em média apenas $5 \mathrm{~cm}$ de diâmetro, fazendo com que a extrapolação lateral destes dados tenha um elevado grau de generalização;

- Há também um elevado grau de generalização nas próprias descrições das amostras o que não permite um maior detalhamento dos materiais superficiais na escala de detalhe exigida pela pesquisa geomorfológica. Além disso, a terminologia utilizada na descrição das texturas dos sedimentos é pouco comum em investigações geomorfológicas. 
O uso de sondagens geológicas em pesquisas de geomorfologia fluvial é criticamente analisado por Houben (2007) que afirma que:

\footnotetext{
“...a reconstituição da arquitetura fluvial por pontos de sondagem é um processo interativo feito por dedução. A evidência granulométrica (mudanças verticais e laterais no tamanho dos sedimentos e tendências apresentadas pelos limites entre corpos sedimentares) é contra balanceada pelas propriedades petrográficas, pela geometria presumida das litofácies e pelo espaçamento entre os elementos arquitetônicos derivados da matriz faciológica investigada" (Houben, 2007 , p. 101, tradução nossa).
}

Ainda segundo este autor, a interpretação morfogenética de fácies sedimentares em ambientes fluviais passa pela classificação de discretos corpos sedimentares tridimensionais que se diferenciam pela textura, estrutura, geometria e localização, cada um desses corpos seria um elemento arquitetônico fluvial (Miall, 1978 e 1996). As sondagens geológicas permitem a identificação apenas da textura e localização. Além disso, o fato das sondagens utilizarem a textura do material como principal atributo de definição de limites pode gerar o equívoco de se agrupar na mesma camada estratigráfica diferentes fácies que são similares apenas na textura.

Porém, apesar dessas deficiências, as mudanças texturais e a geometria (bidimensional) dos corpos sedimentares podem ser consideradas a partir da análise das sondagens, ao menos em estudos em escala de semi-detalhe (HOUBEN, 2007, p. 98).

O acesso a obras de engenharia civil onde ocorriam escavações possibilitou a realização de trabalhos de campo em perfis verticais representativos, que tiveram como objetivo a descrição a partir de observações visuais, fotografias e análises texturais táteis e a coleta de amostra para análises de laboratório.

Para as descrições diretas e coleta de amostras em campo utilizou-se das seguintes ferramentas: trena (5 e 10m); faca de pedólogo; martelo geológico; bússola; pá; enxadão; escadas; máquina fotográfica; sacos para coleta de amostra e; mapas de base para consulta. 
As análises de laboratório se limitaram aos aspectos texturais. Para tal, utilizouse do protocolo do LABOPED (Anexo 1) e da seguinte escala granulométrica:

\begin{tabular}{|c|c|c|c|c|c|c|c|c|c|}
\hline & \multicolumn{9}{|c|}{$\begin{array}{c}\text { Escala utilizada na análise granulométrica. Adaptação das escalas de Wentworth e } \\
\text { do Departamento de agricultura dos Estados Unidos - USDA. }\end{array}$} \\
\hline & \multirow[b]{2}{*}{ Seixo } & \multirow[b]{2}{*}{ Cascalho } & \multicolumn{5}{|c|}{ Areia } & \multirow[b]{2}{*}{ Silte } & \multirow[b]{2}{*}{ Argila } \\
\hline & & & \begin{tabular}{|c|} 
Areia \\
muito \\
grossa \\
\end{tabular} & $\begin{array}{l}\text { Areia } \\
\text { grossa }\end{array}$ & $\begin{array}{l}\text { Areia } \\
\text { média }\end{array}$ & $\begin{array}{l}\text { Areia } \\
\text { fina }\end{array}$ & $\begin{array}{c}\text { Areia } \\
\text { muito } \\
\text { fina }\end{array}$ & & \\
\hline \multirow[t]{2}{*}{ (Tamanho do grã } & & 2,0 & $0 \quad 1$ & 0,5 & 0,25 & 0,12 & & \multicolumn{2}{|c|}{$0,002 \mathrm{~mm}$} \\
\hline & \multicolumn{2}{|c|}{ Pedregulho } & \multicolumn{2}{|c|}{ Areia Grossa } & $\begin{array}{c}\text { Areia } \\
\text { média }\end{array}$ & \multicolumn{2}{|c|}{ Areia fina } & Silte & Argila \\
\hline
\end{tabular}

Devido às diferentes terminologias utilizadas para classificar os materiais superficiais, foi necessário adaptar a terminologia utilizada na descrição textural das sondagens geológicas do Metrô com a terminologia que é mais apropriada para investigações geomorfológicas, como mostra a escala acima.

Além da terminologia específica dos sedimentos, adaptou-se também a terminologia relativa às características do embasamento pré-cambriano. Tendo em vista que na Engenharia o termo "solo" refere-se aos materiais da crosta terrestre que não oferece resistência intransponível à escavação mecânica, independente de se tratar de sedimentos ou solos pedogenéticos (VARGAS,1977, p. 3-4), aquilo que é chamado de "solo residual" e "saprolito" do embasamento pré-cambriano nas sondagens do Metrô, é aqui interpretado como "rocha muito intemperizada" e "rocha medianamente intemperizada", respectivamente.

As observações dos perfis verticais em campo e as análises de laboratório permitiram um maior refinamento das informações das sondagens geológicas do Metrô. Os locais das sondagens geológicas utilizadas e dos perfis verticais observados são apresentados na Figura 19.

Os principais materiais superficiais pesquisados, seja por sondagens geológicas ou por observação de campo e análises de laboratório, foram os sedimentos fluviais do Pleistoceno Superior e Holoceno. Os principais parâmetros sedimentológicos utilizados foram os granulométricos e estratigráficos, possibilitando a compreensão da disposição geral interna dos corpos sedimentares e externa em relação à superfície e ao embasamento geológico (arquitetura fluvial). 


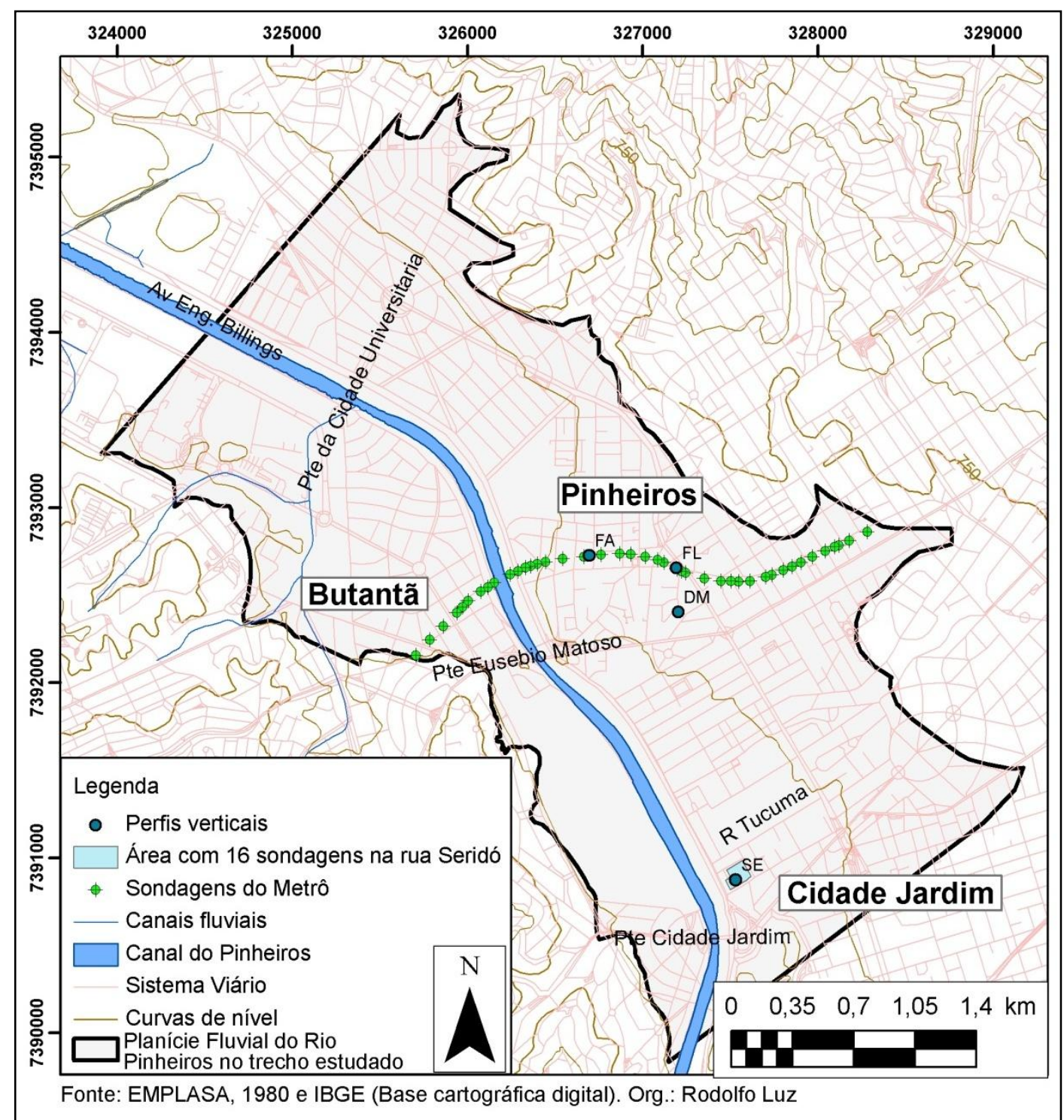

Figura 19 - Locais das sondagens geológicas utilizadas e perfis verticais observados.

Por meio desse instrumental, a análise dos materiais superficiais também permitiu a compreensão de parte da estrutura geológica da planície, para além dos sedimentos mais superficiais. A partir da disposição e constituição do embasamento da planície fluvial foram identificadas, falhas geológicas e, principalmente, a disposição litológica do embasamento pré-cambriano, auxiliando na interpretação geomorfológica.

Parâmetros pedológicos também são importantes na interpretação da história da planície fluvial, como pode ser visto, por exemplo, no conceito de "pedofácies" apresentado por Kraus \& Bown (1986). Porém, eles foram pouco utilizados devido à falta de amostras em campo e à abordagem superficial que eles recebem nas 
sondagens geológicas. Somente análises incipientes e advindas da textura e dos teores de matéria orgânica puderam ser abordadas do ponto de vista pedológico.

Desta maneira, foram obtidas as principais características granulométricas, a geometria aproximada e o posicionamento estratigráfico dos corpos sedimentares. Além disso, algumas unidades morfológicas tiveram seus materiais descritos e algumas características pedológicas puderam ser identificadas.

\subsubsection{Sistematização de Dados}

A sistematização dos dados da carta geomorfológica de detalhe foi realizada através da restituição morfológica, vetorização dos overlays obtidos sobre a base cartográfica, sistematização da legenda, aferições de campo e edição final. Desta maneira, foi alcançado o principal objetivo da confecção da carta, que é o de ser um produto essencial das análises sobre o meio físico da área, reconstituindo assim as características geomorfológicas da região antes da perturbação antrópica.

A base cartográfica foi georreferenciada e vetorizada no software aplicado a Sistemas de Informação Geográfica (SIG) denominado ArcView versão 9.3. A vetorização compreendeu as curvas de nível, a hidrografia e o sistema viário.

O uso de base cartográfica e de fotografias aéreas antigas geram alguns problemas em relação à qualidade cartográfica dos produtos obtidos, pois este material histórico possui distorções oriundas da tecnologia utilizada na época de obtenção, das intempéries do tempo e dos processos de escaneamento pelos quais eles passaram para possibilitar o trabalho em meio digital (SILVA, 2005, p. 71-75).

Soma-se a isso a distorção intrínseca das fotografias aéreas em relação às bases cartográficas. O processo de correção destas distorções é denominado ortorretificação, e implica no conhecimento de componentes e parâmetros da fotografia que não são passíveis de identificação nas aerofotos antigas aqui utilizadas (OKEKE, 2006).

Sendo assim, optou-se por executar um georreferenciamento visual a partir de elementos comuns às fotografias e à base cartográfica, como hidrografia e, principalmente, sistema viário. 
A sistematização dos dados das sondagens geológicas do Metrô, das observações de campo e das análises de laboratório possibilitou a descrição e análise dos materiais superficiais da planície fluvial do rio Pinheiros no setor estudado. Os principais atributos utilizados nesta análise foram a distribuição, o posicionamento, a profundidade, a espessura, a cor e a granulometria, o que permitiu a identificação de níveis orgânicos, argilosos, arenosos, de cascalhos e de seixos.

Todas estas informações, obtidas por meio de diferentes técnicas e documentos, foram articuladas para que os produtos gráficos e cartográficos finais fossem produzidos.

\subsubsection{Análises e Correlações}

A análise geomorfológica da planície fluvial do rio Pinheiros foi realizada levando-se em consideração os preceitos da Geomorfologia Fluvial, especificamente os dos "sistemas meândricos", com base teórico-metodológica fornecida, principalmente, pelos seguintes manuais e estudos: Leopold et al. (1964); Christofoletti (1974 e 1981); Morisawa (1985); Richards (1985); Suguio \& Bigarella (1990); Cunha (1994); Bridge (2003) e; Knighton (1998).

Para tal, foram articuladas as informações dos seguintes níveis descritivos:

- Nível descritivo da macromorfologia dos materiais superficiais: Identificados no perfil transversal da planície no centro da área de estudo e que foi obtido a partir da compilação dos dados das sondagens geológicas do Metrô. Isto possibilitou a distinção de pacotes sedimentares na planície em sua distribuição geométrica bidimensional. Este local foi denominado Perfil Morfo-sedimentológico PinheirosButantã;

- Nível descritivo dos materiais superficiais: A partir de análises de sondagens geológicas diversas e de observações diretas em perfis verticais expostos em escavações de obras de Engenharia Civil, onde foram realizadas. Dois locais foram alvo deste tipo de observação: Rua Diogo Moreira e Rua Seridó; 
- Nível descritivo das formas, oriundo do levantamento das unidades morfológicas, realizado a partir da fotointerpretação da planície fluvial do rio Pinheiros.

O nível interpretativo da pesquisa foi alcançado a partir das correlações espaciais dos parâmetros da investigação geomorfológica destes níveis descritivos. Essa correlação possibilitou a identificação de processos geomorfológicos, o que tornou possível:

- a identificação da morfodinâmica das unidades morfológicas fluviais em seus aspectos erosivos/deposicionais, pedogênicos e hidrodinâmicos;

- a identificação de uma provável sequência de eventos geomorfológicos atuantes no setor estudado durante o Pleistoceno Superior e o Holoceno. 


\section{RESULTADOS}

\subsection{NÍVEL DESCRITIVO E ANALÍTICO}

\subsubsection{Formas: unidades morfológicas identificadas}

As formas identificadas na planície fluvial do rio Pinheiros na área estudada foram sistematizadas em unidades morfológicas conforme o subsistema a que pertencem, de acordo com a estrutura de legenda de Santana (2008) e das sistematizações de Tricart (1965 e 1966), Christofoletti (1974 e 1981); Coutard et al. (1978), Dackombe \& Gardiner (1983), Hart (1986), Lima (1990) e Estaiano (2007) (Figura 20).

Nessa etapa da pesquisa os limites laterais da área de estudo foram redefinidos, já que somente a fotointerpretação torna possível diferenciar os terrenos do sistema fluvial dos terrenos do sistema vertente, demarcados por descontinuidades côncavas, seja angular (ruptura), seja curva (mudança) (SAVIGEAR, 1965, p. 515). Na margem esquerda há rupturas perceptíveis que demarcam o limite entre a planície fluvial e os morros sobre rochas précambrianas. Já na margem direita há mudanças no contato com os terraços de nível intermediário e rupturas no contato com as altas colinas (AB'SABER, 1957), ambos sobre os sedimentos terciários.

Em seus aspectos gerais, percebe-se uma particularidade no limite entre 0 subsistema da planície de inundação e dos terraços fluviais. Há uma nítida redução da extensão lateral da planície de inundação na região central do mapa, assinalando um setor de estreitamento dessa planície em relação aos terraços fluviais. A planície de inundação que apresenta uma extensão lateral média de 1400 metros é reduzida neste setor para cerca de 190 metros.

A Figura 21 e a Tabela 1 apresentam as medidas da largura média do canal e do índice de sinuosidade do rio Pinheiros em seus trechos a montante e a jusante deste setor de estreitamento da planície de inundação.

Tabela 2 - Índice de sinuosidade e largura do canal a montante e a jusante do setor de estreitamento da planície de inundação do rio Pinheiros.

\begin{tabular}{|c|c|c|}
\hline & Largura média (metros) & Índice de sinuosidade (Is) \\
\hline Trecho montante & 25,23 & 2,05 \\
\hline Trecho jusante & 28,06 & 1,73 \\
\hline Total & 26,64 & 1,91 \\
\hline
\end{tabular}




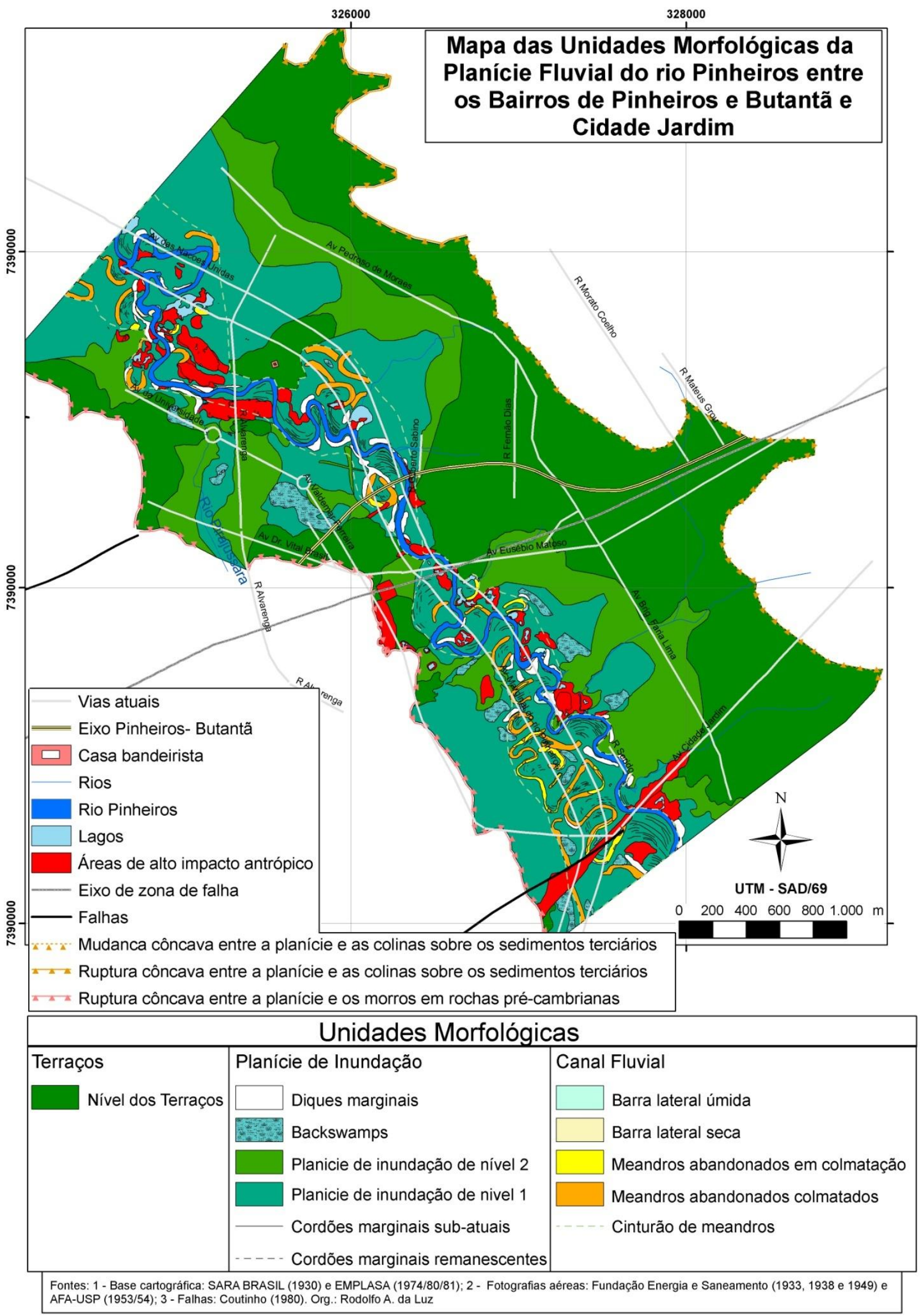

Figura 20 - Unidades morfológicas da área. 


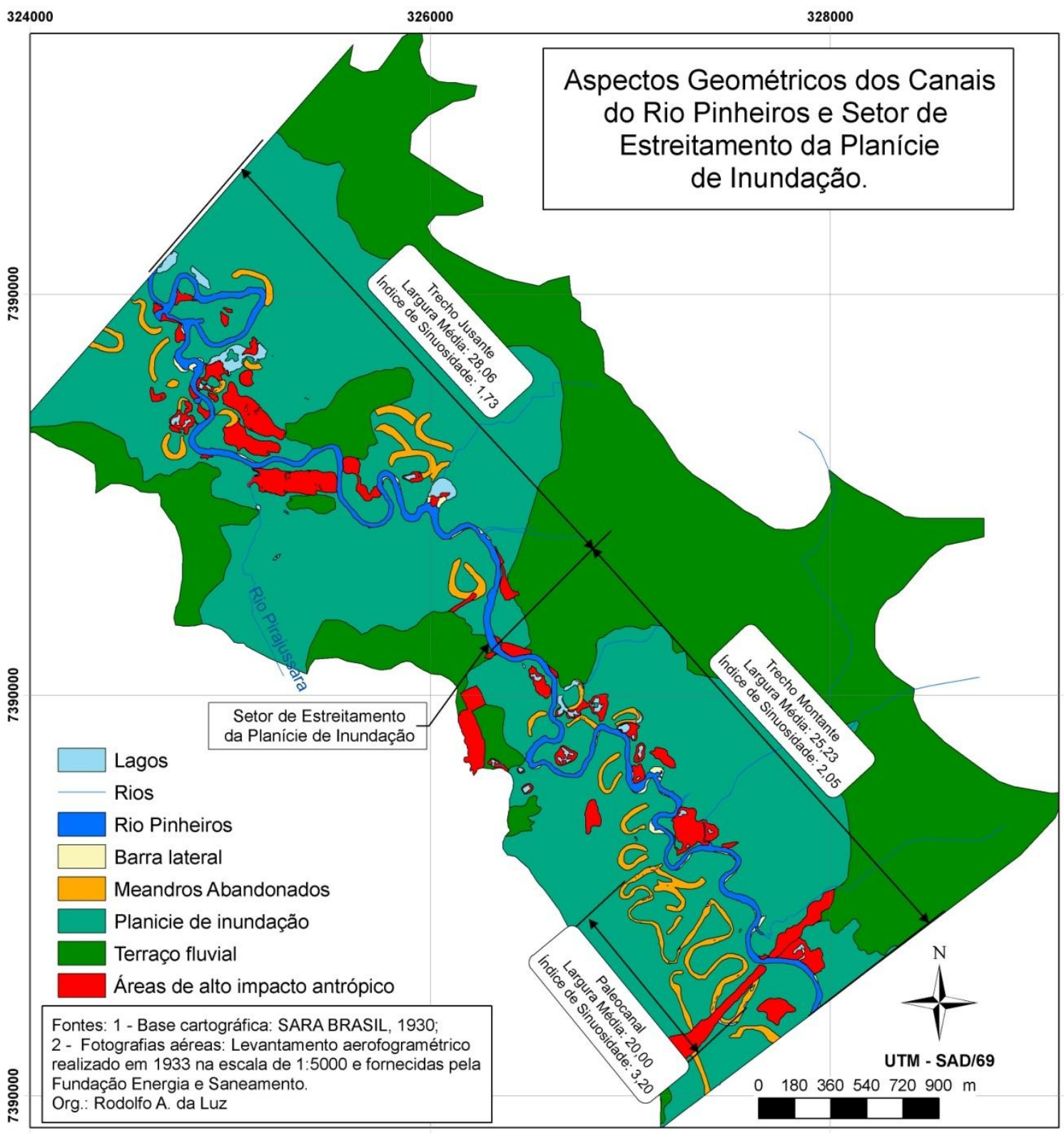

Figura 21 - Aspectos geométricos do canal do rio Pinheiros e meandros abandonados.

A seguir são apresentadas as unidades morfológicas identificadas pelo mapeamento em cada subsistema fluvial meândrico:

\section{Subsistema dos terraços}

Os terraços fluviais possuem limites bem marcados com a planície de inundação e correspondem aos "baixos terraços fluviais" de Ab'Saber (1957) ou ao "baixo terraço" de Petrone (1963). No trecho mapeado esses terraços estariam originalmente em cotas topográficas acima de 724 metros, e são de ocorrência contínua e extensa na margem direita, enquanto que na esquerda são descontínuos e de menor expressão espacial. 


\section{Subsistema da planície de inundação}

A planície de inundação atinge cotas topográficas entre 720 e 722 metros e foi subdividida em:

- Diques marginais - definidos principalmente pelos seus aspectos tridimensionais visualizados em estereoscopia, onde se configuram como elevações ao longo das margens do canal fluvial ativo ou abandonado.

- Cordões marginais - se apresentam como alinhamentos subparalelos as margens dos canais onde a vegetação tem um maior porte arbóreo. Foram subdivididos conforme a sua localização em: 1) cordões sub-atuais, que são testemunhos de processos de migração lateral do canal fluvial ativo do rio Pinheiros e; 2) cordões remanescentes, que testemunham processos mais antigos ocorridos quando os canais abandonados eram ativos.

- Backswamps (Planície de inundação isolada) - Terrenos isolados mais baixos que os do entorno, apresentando maior umidade devido à proximidade do lençol freático e com vegetação rasteira e de pequeno porte.

O restante da planície de inundação foi compartimentada em dois níveis altimétricos. O Nível 2 se trata de pequenas elevações que não apresentam rupturas com o Nível 1, apenas uma mudança muito suave e, algumas vezes, de difícil delimitação. Em alguns locais o nível 2 se configura como uma rampa suave entre o nível 1 e os terraços fluviais, principalmente na margem direita do rio. Ab'Saber (1957, p.148) indica a existência destes diferentes níveis (planície de inundação sujeita a inundações anuais para o nível 1, e planície de inundação sujeita apenas às grandes cheias para o nível 2).

Algumas elevações isoladas próximas a altitude do nível 2 foram classificadas como "elevações indiferenciadas" por não terem continuidade lateral expressiva.

\section{Subsistema do canal}

- Barras laterais - localizam-se nas margens do canal fluvial ativo e foram classificadas como: 1) secas, onde as águas do canal não as cobrem, 
formando praias e apresentando cores bem claras, próximas ao branco e; 2) úmidas, onde as águas as cobrem, porém é possível verificar que o canal é bastante raso.

Os cordões marginais presentes na planície de inundação são antiga barras laterais.

- Meandros abandonados - foram subdivididos de acordo com o grau de colmatagem, identificado na fotografia aérea através da umidade do meandro. Cores claras indicam terrenos secos e já colmatados, enquanto as cores escuras indicam setores úmidos e em processo de colmatação.

O local onde os meandros abandonados são mais expressivos, chegando a formar um paleocanal com 2,83 km de extensão, está à montante do setor de estreitamento da planície de inundação, na porção sul da carta na margem esquerda do rio Pinheiros. Este paleocanal tem em média 20 metros de largura e 3,20 de índice de sinuosidade (Is) (Figura 21).

A partir dos meandros abandonados foi possível delimitar o cinturão de meandros, que corresponde a área na qual o rio deslocou-se lateralmente e que se localiza totalmente no nível 1 da planície de inundação.

\subsubsection{Materiais correlacionados as formas}

Os materiais superficiais aqui descritos se dividem entre os do eixo da Linha 4 - Amarela do Metrô, denominado "Perfil Morfo-sedimentológico PinheirosButantã" e os de outros dois locais onde foi possível o acesso às escavações que ali ocorriam, Rua Diogo Moreira e Rua Seridó (Figura 22).

\subsubsection{Perfil Morfo-sedimentológico Pinheiros-Butantã}

Optou-se por esta denominação devido ao fato deste perfil localizar-se entre esses dois bairros paulistanos. Trata-se de uma seção aproximadamente transversal da planície fluvial com pouco mais de $2,9 \mathrm{~km}$ de extensão elaborada a partir da compilação e análise de informações de sondagens geológicas realizadas pelo Metrô de São Paulo (Anexo 2) e da correlação deste perfil com as unidades morfológicas anteriormente descritas (Figura 22). 


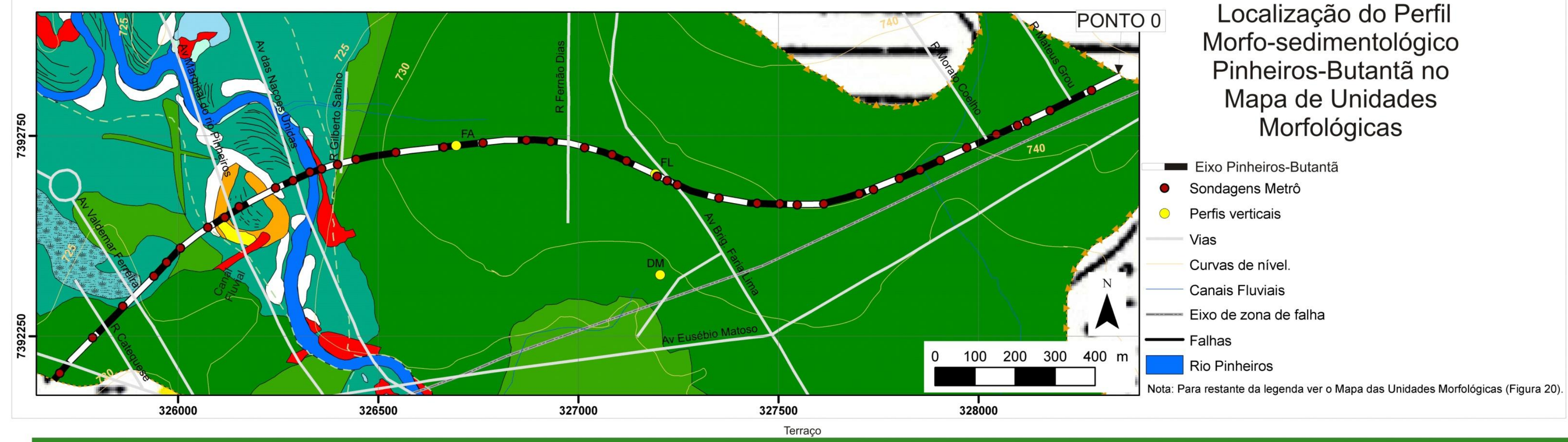

Localização do Perli

Pheiros-Butantã no
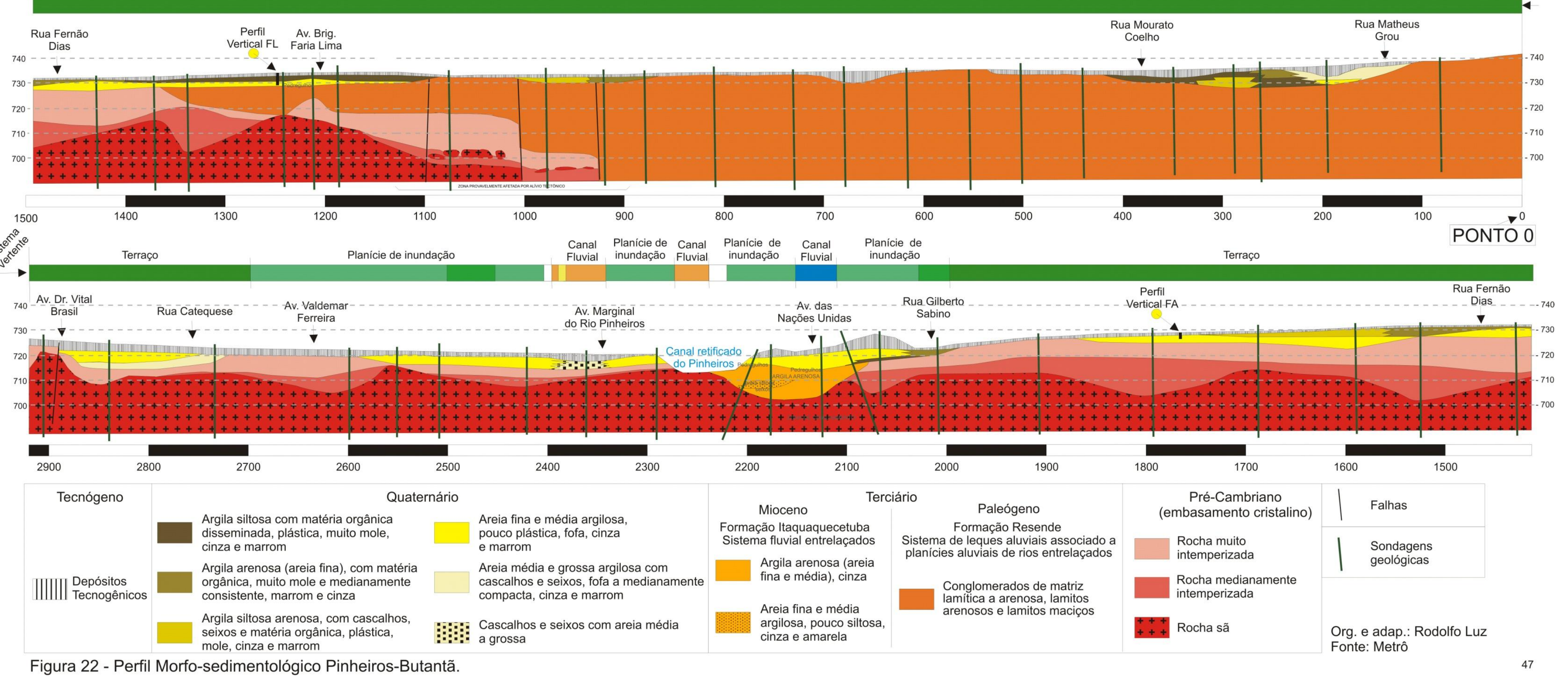

Figura 22 - Perfil Morfo-sedimentológico Pinheiros-Butantã. 
Pode-se visualizar no Perfil Morfo-sedimentológico Pinheiros-Butantã a estrutura superficial e sub-superficial de parte da planície fluvial do rio Pinheiros, englobando os materiais dos três subsistemas: canal fluvial, planície de inundação e terraços. As transições e descontinuidades entre os pacotes sedimentares são representadas de forma bidimensional, apresentando parte da arquitetura fluvial da planície (MIALL, 1978 e 1996).

$\mathrm{Na}$ descrição que segue, as distâncias consideradas têm como base a leitura do Perfil Morfo-sedimentológico Pinheiros-Butantã no sentido NE-SO, ou seja, da região próxima a Rua Matheus Grou no bairro de Pinheiros em direção a Av. Dr. Vital Brasil, já no Butantã. Este ponto inicial é aqui denominado de "Ponto 0". Entre o Ponto 0 e o fim do perfil são percorridos cerca de 2900 metros.

\section{Subsistema dos terraços fluviais}

É o subsistema de maior expressão no perfil. Na margem direita do canal fluvial ele é mais extenso (cerca de $2 \mathrm{~km}$ de extensão) e possui altitude média de pouco mais de 730 metros. Na margem esquerda ele é menor, com pouco mais de 200 metros de extensão e altitude média de 725 metros.

Ambas as margens apresentam terraços em rampas, com declividades em torno de $0,66 \%$ no topo que aumentam progressivamente em direção a planície de inundação, chegando a $3 \%$ de declividade nas bordas dos terraços.

1) Terraço fluvial da margem direita

De acordo com o perfil construído, nos setores mais distantes do canal fluvial e da planície de inundação os terraços fluviais da margem direita não apresentam sedimentos quaternários de forma contínua e expressiva, estando a maior parte dos depósitos tecnogênicos assentada diretamente sobre os sedimentos de idade terciária da Formação Resende. A ocorrência de sedimentos quaternários é restrita, e está associada aos locais onde pequenos afluentes cortam o Perfil Morfo-sedimentológico Pinheiros-Butantã, como é o caso da região entre as ruas Matheus Grou e Mourato Coelho, pouco abaixo de 740 metros de altitude. 
Os sedimentos quaternários ganham continuidade a cerca de 1100 metros do Ponto 0, em local próximo a Av. Brig. Faria Lima, ainda sobre a Formação Resende. Porém, nota-se também a maior proximidade do embasamento précambriano, que, neste ponto, está numa profundidade de 15 metros (na forma de rocha intemperizada).

A partir deste local a Formação Resende vai progressivamente tornando-se menos espessa até cerca de 1360 metros de distância do Ponto 0, onde os sedimentos quaternários já estão assentados diretamente sobre 0 embasamento pré-cambriano intemperizado. Daí em diante não há mais registros da Formação Resende no Perfil Pinheiros-Butantã, estando a camada de rocha sã do embasamento pré-cambriano a uma cota média de 710 metros (cerca de 20 metros abaixo da superfície do terraço).

Os sedimentos quaternários ocorrem de forma mais contínua a partir de 1100 metros do Ponto 0, e possuem, em média, 5 metros de profundidade. Primeiramente, apresentam-se em camadas de sedimentos finos com matéria orgânica (classificada pelas sondagens do Metrô como "argila siltosa com matéria orgânica disseminada") sobre uma camada arenosa e sem matéria orgânica (classificada pelas sondagens como "areia fina e média argilosa").

A camada do topo, ainda com predomínio dos finos, registra a presença de areias a cerca de 1430 metros do Ponto 0 até cerca de 1550 metros de distância, quando ela se espessa e atinge o embasamento cristalino em substituição da camada mais arenosa inferior.

Após este ponto a declividade na superfície aumenta de 0,66\% para $1 \%$, e a camada arenosa inferior torna a aparecer. A camada superior continua a apresentar matéria orgânica e textura mais fina que a inferior, porém, com registro de "pedregulhos" (cascalhos e seixos). A cerca de 1720 metros do ponto 0 , a camada superior de sedimentos mais finos desaparece, restando somente a camada arenosa da base, que ocorre até cerca de 1860 metros de distância.

Neste ponto não há mais registros de sedimentos quaternários e as rochas intemperizadas do embasamento pré-cambriano alcançam a superfície, 
justamente quando esta aumenta sua declividade para $3 \%$, já no limite entre o terraço fluvial da margem direita do rio Pinheiros e a planície de inundação.

Neste terraço fluvial foram realizados levantamentos de campo em dois pontos, um na Av. Faria Lima, denominado "Perfil Vertical FL" e outro na Rua Ferreira de Araújo, denominado "Perfil Vertical FA".

O Perfil Vertical FL é apresentado na Figura 23 e Prancha 1.

No Perfil Morfo-sedimentológico Pinheiros-Butantã ele localiza-se a cerca de 1240 metros de distância do Ponto 0. Neste local, as sondagens do Metrô indicam para o Quaternário a seguinte disposição: depósitos tecnogênicos até cerca de 1,5 metros de profundidade; camada superior argilo-siltosa entre 1,5 e 3,5 metros e; camada arenosa entre 3,5 e 5,5 metros.

Aumentando a escala de observação através do Perfil Vertical FL, detalhamos então esta composição estratigráfica.

Verificou-se por meio da caracterização táctil-visual que os depósitos tecnogênicos são compostos por piso, asfalto e camadas alaranjadas e avermelhadas de aterros contemporâneos as obras de construção da avenida. A camada superior argilo-siltosa com matéria orgânica que consta no Perfil Morfo-sedimentológico Pinheiros-Butantã é subdividida em: uma fina camada argilosa e negra sobre; sedimentos argilosos cinza-escuro sobre; sedimentos areno-argilosos cinza sobre; areno-argilosos cinza-claro.

A camada arenosa inferior é representada por sedimentos arenosos sobre uma camada de cascalhos e seixos, ambos em tonalidades claras. Portanto, aquilo que é chamado de "areias finas a médias argilosas" pelas sondagens do Metrô aparece no Perfil Vertical FL como areias sobre cascalhos e seixos.

Este perfil vertical nos mostra claramente que, abaixo dos depósitos tecnogênicos há um aumento gradual das frações granulométricas em direção a base, acompanhado de uma diminuição no teor de matéria orgânica representada também pela diminuição gradual das tonalidades escuras. 


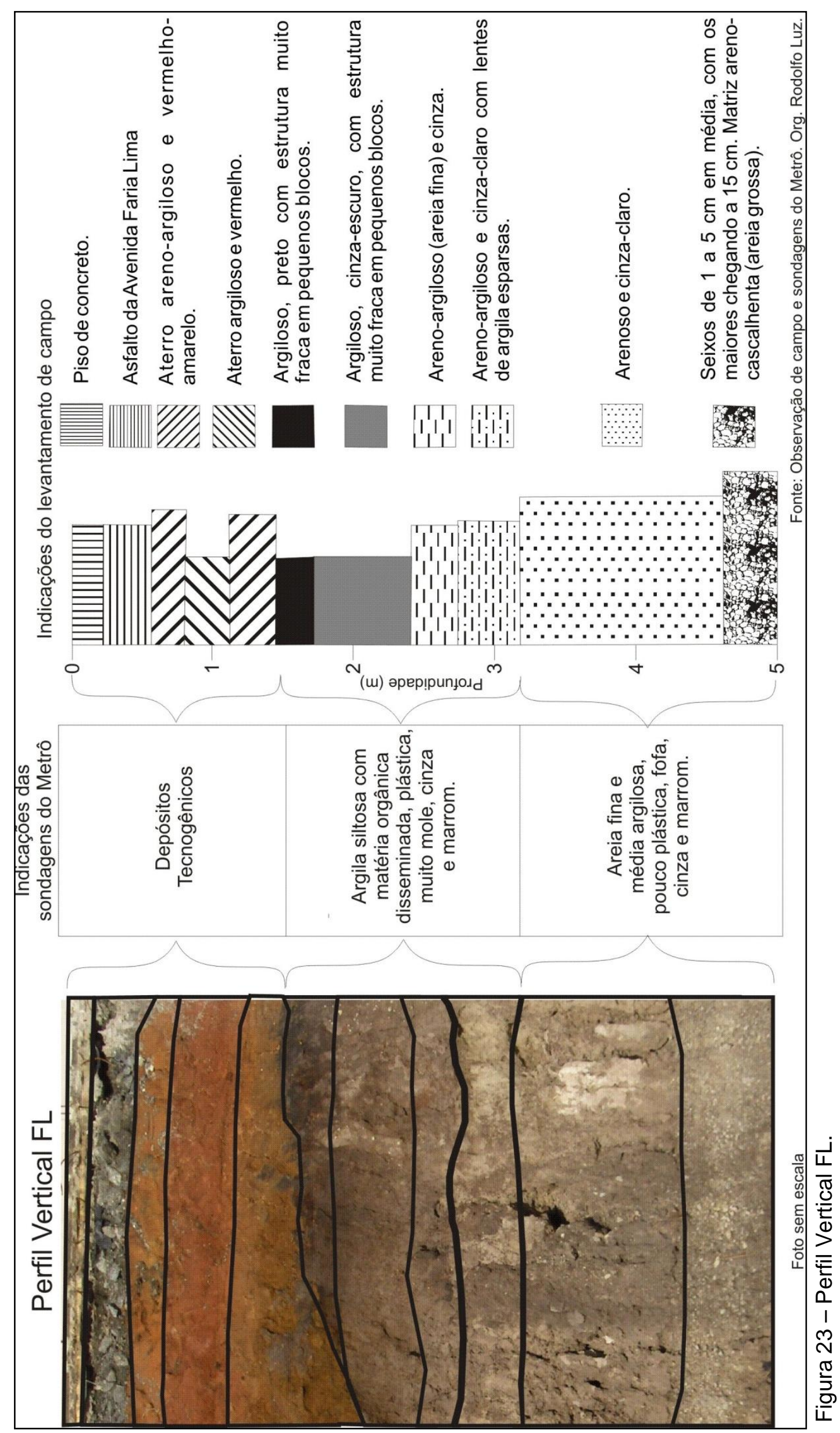


Prancha 1: Perfil Vertical FL.

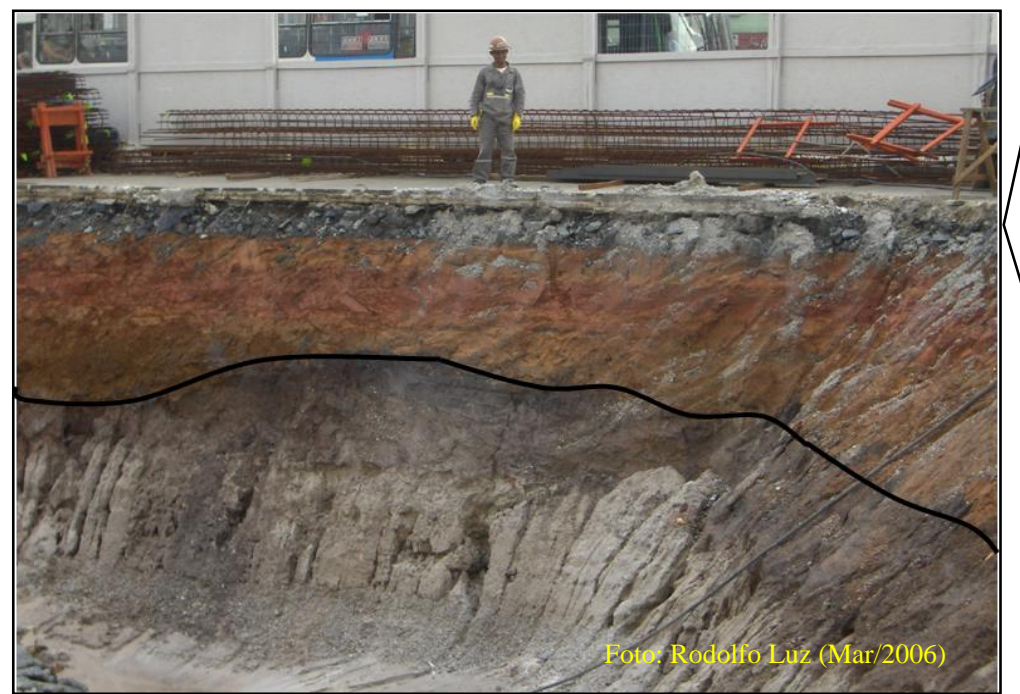

Vista geral da escavação do Metrô com destaque para o contato entre os depósitos tecnogênicos e os sedimentos fluviais. Este local era atravessado pela Av. Faria Lima antes da obra.
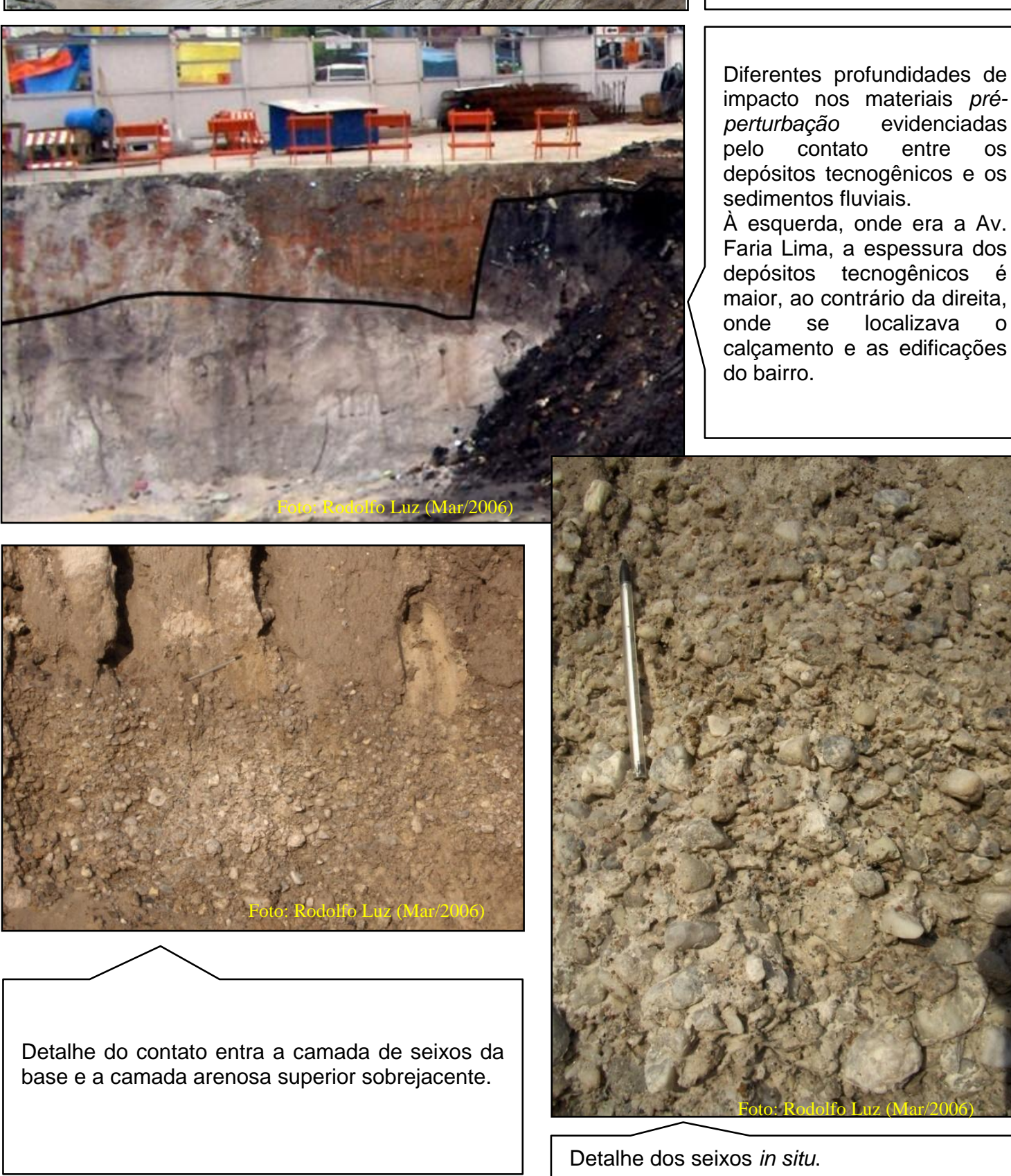

Diferentes profundidades de impacto nos materiais préperturbação evidenciadas pelo contato entre os depósitos tecnogênicos e os sedimentos fluviais.

À esquerda, onde era a Av. Faria Lima, a espessura dos depósitos tecnogênicos é maior, ao contrário da direita, onde se localizava o calçamento e as edificações do bairro. 
O Perfil Vertical FA é apresentado na figura 26 e Prancha 2.

No Perfil Morfo-sedimentológico Pinheiros-Butantã ele se localiza a cerca de 1770 metros de distância do Ponto 0, onde as sondagens do Metrô indicam que os depósitos tecnogênicos atingem cerca de 1 metro de profundidade, e a camada de sedimentos quaternários é representada somente pela camada de areia fina a média argilosa até cerca de 4,1 metros.

O Perfil Vertical FA detalha a estratigrafia deste ponto. Nele vemos que 0 depósito tecnogênico é composto apenas por uma fina camada de piso de uma residência com pouco mais de 14 centímetros, diferentemente do 1 metro de espessura apresentado pelas sondagens do Metrô. A camada de sedimentos arenosos quaternários ("areia fina a média argilosa") é representada por várias camadas que com grande variação de cores e textura.

Além da camada tecnogênica (camada 1), foram identificadas por caracterização táctil-visual e análise granulométrica mais 9 camadas no Perfil Vertical FA, sendo:

- De 0,14 a 1,30 m: Duas camadas superiores arenosas (mais de 70\% de areia), com predomínio das areias finas e médias, cores escuras, raízes e relativo aumento nos teores de argila, que aumenta de $13 \%$ na camada superior para $18 \%$ na inferior. Estas camadas apresentam características típicas de horizontes onde atuam processos pedológicos, como fracas estruturas em blocos, matéria orgânica e provável ocorrência de processos de acumulação por iluviação de argila. $\mathrm{Na}$ camada mais superior foram encontrados fragmentos antrópicos como acrílico e cerâmica.

- De 1,30 a 2,20 m: Quatro camadas intermediárias brunas e acinzentadas e com granulometria bastante variada, como pode ser visto na mudança abrupta que há entre os valores de areias e cascalhos a cerca de 1,60 m de profundidade (aumento de $20 \%$ nas areias e diminuição de $35 \%$ de cascalhos). As camadas inferiores, apesar de apresentarem cores semelhantes as das duas superiores, têm a granulometria diferente, apresentando o aumento gradual nos valores de 
cascalhos (de 33 para 37\%) e uma diminuição nos de argila e silte (de 14 para $10 \%$ ). Os valores de areia são semelhantes (em torno de 52\%).

- De 2,20 a 2,60 m: Três camadas inferiores com baixos teores de silte e argila e predomínio de areias grossas e cascalhos. As duas camadas superiores são mais amareladas do que a inferior, que já se apresenta bastante clara, indicando um ambiente redutor devido a presença de água do lençol freático.

Portanto, parece que as camadas pedológicas superiores do Perfil Vertical FA foram consideradas como depósitos tecnogênicos pelas sondagens do Metrô (Figura 24). Abaixo destas, o Perfil Vertical FA apresenta camadas intermediárias de tonalidades brunas e cinzas sobre as camadas amarelas e claras da base. Do ponto de vista granulométrico, as camadas abaixo das pedológicas não apresentam continuidade, ocorrendo algumas mudanças abruptas entre as texturas de camadas adjacentes.

No geral, as 7 camadas inferiores do Perfil Vertical FA apresentam predomínio de cascalhos e areias grossas e, assim como no caso do Perfil Vertical FL, compreendem a camada de "areia fina e média argilosa" nas sondagens do Metrô. 


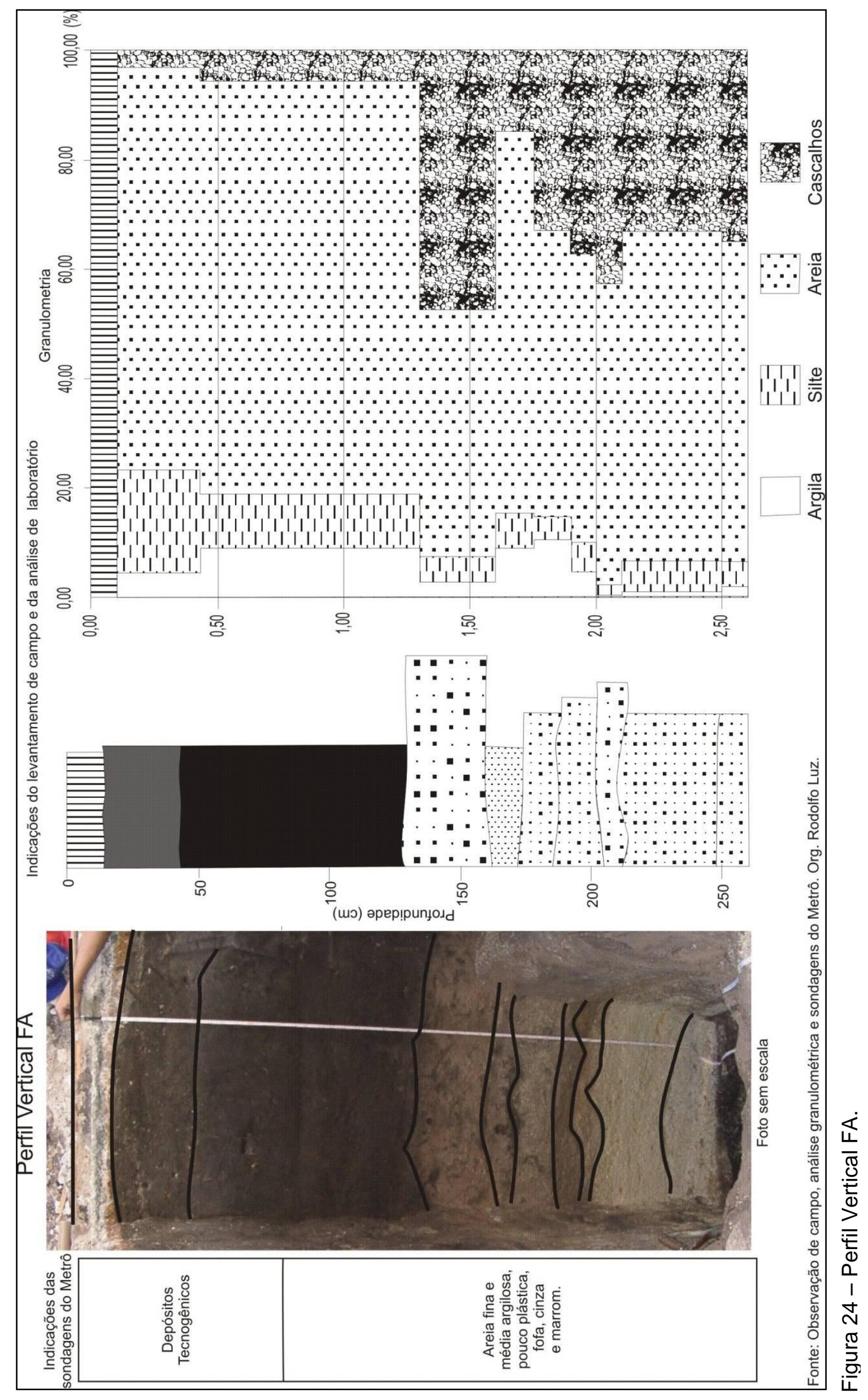


Prancha 2: Perfil Vertical FA.

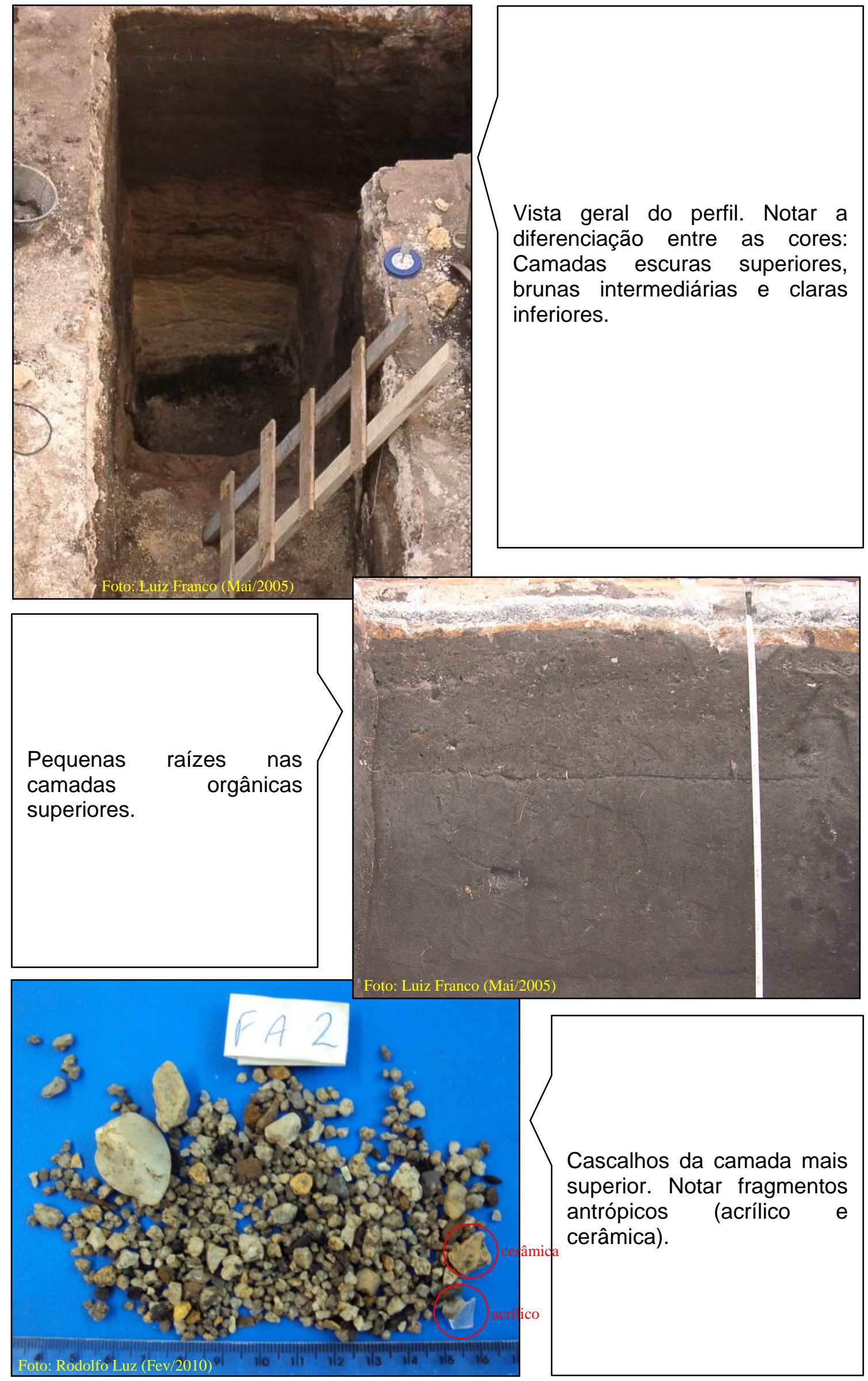




\section{Terraço fluvial da margem esquerda}

A cerca de 2700 metros de distância do Ponto 0 do Perfil Morfo-sedimentológico Pinheiros-Butantã ocorre o limite entre a planície de inundação e o terraço fluvial da margem esquerda. Assim como no caso da margem direita, neste limite também há afloramento do embasamento pré-cambriano intemperizado.

Os sedimentos quaternários ocorrem a cerca de 2720 metros Ponto 0 , abaixo de depósitos tecnogênicos que possuem 3 metros de espessura em média. Estes sedimentos quaternários são diferenciados em duas camadas pelas sondagens do Metrô: 1) areia fina e média argilosa superior, com cerca de 4 metros de espessura sobre; 2) areia média e grossa argilosa com pedregulhos, com cerca de 3 metros de espessura.

No limite entre o terraço e o sistema vertente a rocha sã do embasamento précambriano aproxima-se da superfície, ultrapassando a cota de 720 metros, a apenas 5 metros de profundidade.

Assim como na margem direita, as texturas mais grosseiras também ocorrem na porção inferior do pacote sedimentar quaternário. Porém, os sedimentos da margem esquerda são, no geral, mais grosseiros do que os da direita, e não apresentam matéria orgânica.

\section{Aspectos gerais da correlação entre os terraços fluviais e os materiais}

\section{superficiais}

Foram utilizados dois diferentes levantamentos para a análise do nível descritivo dos materiais superficiais dos terraços do Perfil Morfo-sedimentológico PinheirosButantã. A leitura integrada entre os dados oriundos ora de sondagens geológicas, ora de levantamentos de perfis verticais em campo e laboratório, além de permitir algumas considerações a respeito destes materiais superficiais, permite também a análise das diferenças entre os dados obtidos por cada levantamento.

Os perfis verticais de campo ( $F L$ e $F A$ ) indicam que a camada descrita nas sondagens do Metrô como "areia fina e média argilosa" apresentariam, na realidade, predomínio de areias grossas e cascalhos. Isso é mais evidente nos setores mais inferiores, onde essas sondagens indicam a presença de "pedregulhos". Esta diferença mostra as deficiências do uso das sondagens 
para análises interpretações morfogenéticas, como atentado anteriormente e demonstrado por Houben (2007).

Mesmo assim, ao analisar essas informações conjuntamente numa escala de menor detalhe, pode-se considerar que este setor do subsistema dos terraços fluviais do rio Pinheiros apresenta as seguintes características:

- Terraços relativamente mais amplos e mais altos na margem direita do rio do que na esquerda;

- Na margem direita, pouca representatividade dos sedimentos quaternários nas regiões mais distantes da planície de inundação e do canal, e predomínio dos materiais superficiais identificados como sedimentos da Formação Resende;

- Nestas regiões mais distantes da planície de inundação e do canal as ocorrências de sedimentos quaternários estão associadas a canais fluviais afluentes do rio Pinheiros e que atravessam os terraços, como é o caso da região entre as ruas Matheus Grou e Mourato Coelho.

- No geral, sedimentos quaternários preferencialmente sobre as rochas intemperizadas do embasamento pré-cambriano (solo residual). $\mathrm{Na}$ margem direita os sedimentos quaternários atingem em média 4 metros de espessura, e na esquerda são mais espessos, atingindo até 7 metros de espessura.

- No geral, os materiais superficiais identificados como sedimentos quaternários apresentam uma tendência de diminuição da quantidade de areias e cascalhos em direção à superfície, acompanhado de um aumento no teor de matéria orgânica. Esta granodecrescência ascendente é clara no Perfil Vertical FL, corroborando com a interpretação de gênese fluvial desses níveis;

- Ausência significativa de sedimentos quaternários nos limites entre os terraços fluviais e a planície de inundação. Nestes locais há o afloramento do embasamento pré-cambriano. Isso permite a proposição de que estes terraços fluviais sejam classificados como "terraços 
rochosos" (strath terraces), conforme Christofoletti (1981, p 255-258) e Goudie (2006, p. 1041), mesmo não apresentando todas as características que comumente estão associadas a este tipo de terraço.

- Depósitos tecnogênicos menos espessos na margem direita (média de 1 metro) do que na esquerda (média de 3 metros).

\section{$\underline{\text { Subsistema da planície de inundação }}$}

Localiza-se entre as distâncias de 2000 e 2700 metros do Ponto 0, sendo intercalado por unidades morfológicas do canal fluvial. Na margem direita do canal ativo alcança a altitude de 722 metros, enquanto que na margem esquerda se mantém próximo a altitude de 720 metros. A camada de rocha sã do embasamento mantém a cota média de 710 metros, porém se eleva em alguns locais, alcançando a cota de 716 metros onde está o canal retificado do Pinheiros.

O mapa morfológico indica um pequeno trecho do nível altimétrico 2 da planície de inundação entre 2450 e 2500 metros, porém nenhuma distinção entre os materiais superficiais é apresentada pelas sondagens do Metrô entre este nível e o restante da planície de inundação que está no nível 1.

Os depósitos tecnogênicos possuem de 1 a 2 metros de profundidade em média. A cerca de 2060 metros de distância do Ponto 0 há um depósito tecnogênico de 6 metros de espessura, formando uma elevação de cerca de 5 metros na superfície.

Sedimentos quaternários são registrados na maior parte da planície de inundação, com uma espessura média de 4 metros. Somente a cerca de 2590 metros do Ponto 0, nas proximidades da Av. Valdemar Ferreira, é que eles não ocorrem.

A maior parte dos sedimentos quaternários são descritos como "areia fina e média argilosa" pelas sondagens do Metrô, porém podem se tratar de sedimentos mais grosseiros, onde predominam areias grossas e cascalhos, como visto nos perfis verticais "FL e "FA".

Apenas um local da planície de inundação apresenta camadas diferentes. Este local está no limite da planície de inundação com o terraço fluvial da margem direita (2000 metros do Ponto 0, altura da Rua Gilberto Sabino) e registra a 
ocorrência de sedimentos mais finos, caracterizados como argilas siltosas ou arenosas com matéria orgânica. Inclusive, a camada mais fina de todas se localiza na base do Quaternário, abaixo da camada arenosa e em contato direto com o embasamento pré-cambriano, ao contrário do que foi visto nos terraços fluviais, onde não há registros da ocorrência de sedimentos finos em camadas inferiores.

A interpretação geomorfológica destes sedimentos finos isolados dentro da planície de inundação ficou comprometida pela falta de informações morfológicas seguras do local, já que ele se encontra numa zona não recoberta pelo principal aerolevantamento utilizado (1933).

\section{$\underline{\text { Subsistema do canal fluvial }}$}

Ocorre dentro da planície de inundação em duas unidades morfológicas:

\section{1) Canal fluvial ativo}

Entre 2110 e 2210 metros do Ponto 0 , correspondendo ao local onde há os registros mais profundos de sedimentos quaternários no perfil, que atingem a cota de 713 metros.

Os depósitos tecnogênicos possuem de 1,5 a 2,5 metros de profundidade e os sedimentos quaternários registrados correspondem a camada mais típica do perfil, que é a de "areia fina e média argilosa" que, provavelmente, apresenta sedimentos mais grosseiros como visto nos perfis verticais "FL" e "FA".

O que mais chama a atenção neste trecho é o retorno das formações terciárias entre os depósitos quaternários e o embasamento pré-cambriano. Neste local foi identificado um pacote de sedimentos terciários com cerca de 14 metros de espessura e que atinge a cota de 702 metros (20 metros abaixo da superfície). As sondagens do Metrô associam estes sedimentos à Formação Resende, porém, algumas características fazem com que ela seja associada à Formação Itaquaquecetuba (RICCOMINI et al., 2004, p. 401-402), como segue:

- ocorrência espacial diretamente relacionada ao canal ativo do rio Pinheiros em sua fase pré-perturbação;

- ocorrência sobre as rochas sãs do embasamento cristalino; 
- nenhuma relação estratigráfica com as unidades paleógenas anteriores (Formação Resende e Formação São Paulo).

É importante ressaltar nestes sedimentos terciários aqui interpretados como fazendo parte da Formação Itaquaquecetuba, a forma de canal identificada pelas sondagens do Metrô (Figura 25). Isto indica que provavelmente houve neste setor uma ação de incisão fluvial sobre as rochas do embasamento pré-cambriano, que resultou nos depósitos fluviais terciários da Formação Itaquaquecetuba, e que foram posteriormente recobertos pelos sedimentos fluviais quaternários do rio Pinheiros.

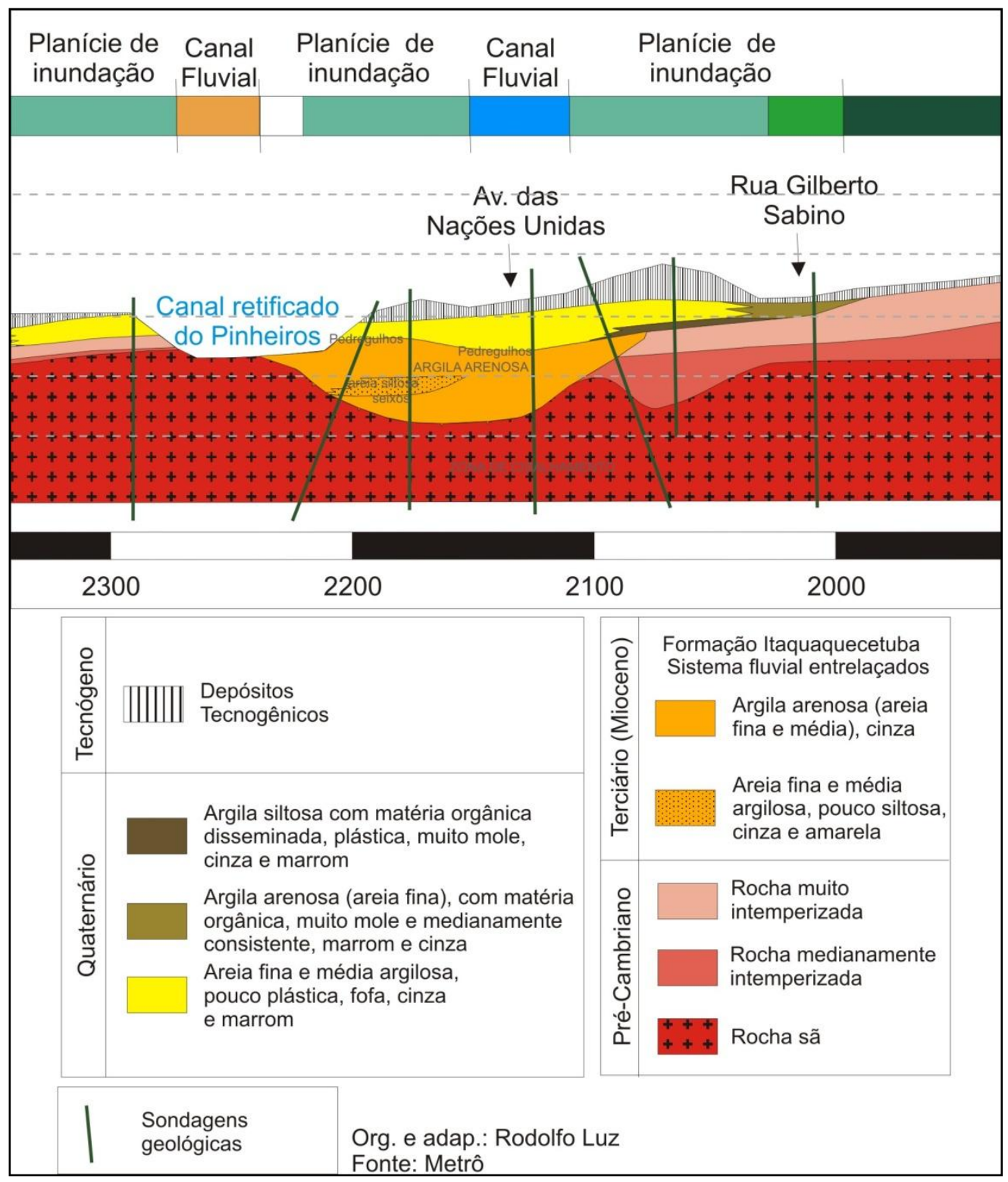

Figura 25 - Formação Itaquaquecetuba no Perfil Morfo-sedimentológico Pinheiros-Butantã. 


\section{Meandros abandonados}

Ocorrem em dois locais, entre 2240 e 2270 metros e entre 2340 e 2400 metros de distância do Ponto 0 . No primeiro local não há registros válidos sobre os materiais superficiais, pois ele já havia sido escavado durante a retificação e instalação canal do Pinheiros.

Resta apenas o registro do segundo local, onde a superfície de contato entre os depósitos tecnogênicos e os sedimentos quaternários sofre um rebaixamento de aproximadamente 1 metro em relação à planície de inundação. Isto demonstra que este meandro abandonado provavelmente era cerca de 1 metro mais baixo do que a planície de inundação antes do aterramento (depósitos tecnogênicos).

Os sedimentos quaternários registrados são os mais grosseiros de todo perfil, descritos pelas sondagens do Metrô como "pedregulhos com areia média a grossa". Este pode ser um indicativo dos materiais superficiais que ocorrem nos meandros abandonados da planície fluvial, porém, a falta de mais amostras não permite este tipo de generalização.

Dentro de um sistema fluvial espera-se que as cotas topográficas mais baixas sejam as do canal fluvial. No caso de uma área urbanizada, a superfície préperturbação seria representada pelo limite entre Tecnógeno e Quaternário. Porém, na região do canal fluvial ativo não foi possível identificar este rebaixamento como no caso do meandro abandonado. Propuseram-se neste estudo alguns motivos para este resultado conflitante:

- A superfície aparentemente mais baixa do meandro abandonado seria resultado de intervenções antrópicas anteriores à deposição tecnogênica. Estas intervenções (mineração, por exemplo) teriam retirado os sedimentos quaternários superiores que, teoricamente, deveriam ser mais finos e orgânicos no topo do meandro abandonado;

- A remobilização dos sedimentos pela mineração neste trecho da planície fluvial onde estaria o canal ativo no estagio pré-perturbação, teria alterado a disposição dos sedimentos quaternários a tal ponto, que não permitisse a realização de uma associação direta entre materiais e 
formas nesta escala de detalhe a partir de dados oriundos apenas de sondagens geológicas.

\subsubsection{Outros locais investigados}

Em outros dois locais da planície fluvial no setor estudado foi possível investigar os seus materiais superficiais através de sondagens geológicas (Anexo 3) e levantamentos de campo, gerando alguns dados de caráter pontual. Estes locais não estão localizados no Perfil Morfo-sedimentológico Pinheiros-Butantã e estão plotados na Figura 19.

\section{$\underline{\text { Rua Diogo Moreira (DM) }}$}

Localiza-se no bairro de Pinheiros e, segundo o mapa morfológico, num terraço fluvial, ainda que numa zona de contato com a planície de inundação e próximo a um canal afluente do rio Pinheiros (inferido pela forma côncava à montante das curvas de nível). Seus materiais superficiais são apresentados nas Figuras 26 e 27 e na Prancha 3, configurando uma pequena amostra dos materiais deste tipo de contato (terraço fluvial / planície de inundação).

Os sedimentos quaternários possuem em média 4 metros de profundidade, e estão sobre sedimentos terciários, provavelmente da Formação Resende, que atingem entre 13 e 16 metros de profundidade.

A figura 27 apresenta um perfil de 20 metros de extensão e pouco mais de 2 metros de profundidade (Perfil Vertical DM), paralelo ao canal fluvial afluente do rio Pinheiros. Em seus aspectos gerais, este perfil mostra no topo uma camada argilo-arenosa, preta e com matéria orgânica de cerca de $30 \mathrm{~cm}$ em média, mas que tende a se tornar menos espessa em direção à planície de inundação. Na base do perfil há uma camada argilosa com seixos e cascalhos esparsos, com aumento das areias em profundidade.

Entre essas duas camadas há uma diferenciação. Na porção NE há uma transição gradual representada por uma camada areno-argilosa brunoacinzentada. Ainda nesta porção, destaca-se uma feição irregular bruna e areno-argilosa com lentes de seixos e cascalhos que chega a quase $180 \mathrm{~cm}$ de profundidade. 
Na porção SO, há uma extensa camada de cascalhos e seixos de espessura variada, mas que tende a se espessar em direção a planície de inundação, atingindo $80 \mathrm{~cm}$ de espessura. Esta camada pode representar os depósitos de canal do afluente do rio Pinheiros que atravessava esta área, numa zona de contato da base do terraço fluvial e a planície de inundação.

Esta zona de contato entre duas unidades geomorfológicas poderia demarcar uma diminuição significativa e abrupta no gradiente deste canal, o que pode ter influenciado numa possível tendência dele depositar a sua carga mais grosseira neste local, por causa da perda de competência de seu fluxo que ali ocorreria devido à diminuição do gradiente.

Prancha 3: Rua Diogo Moreira.

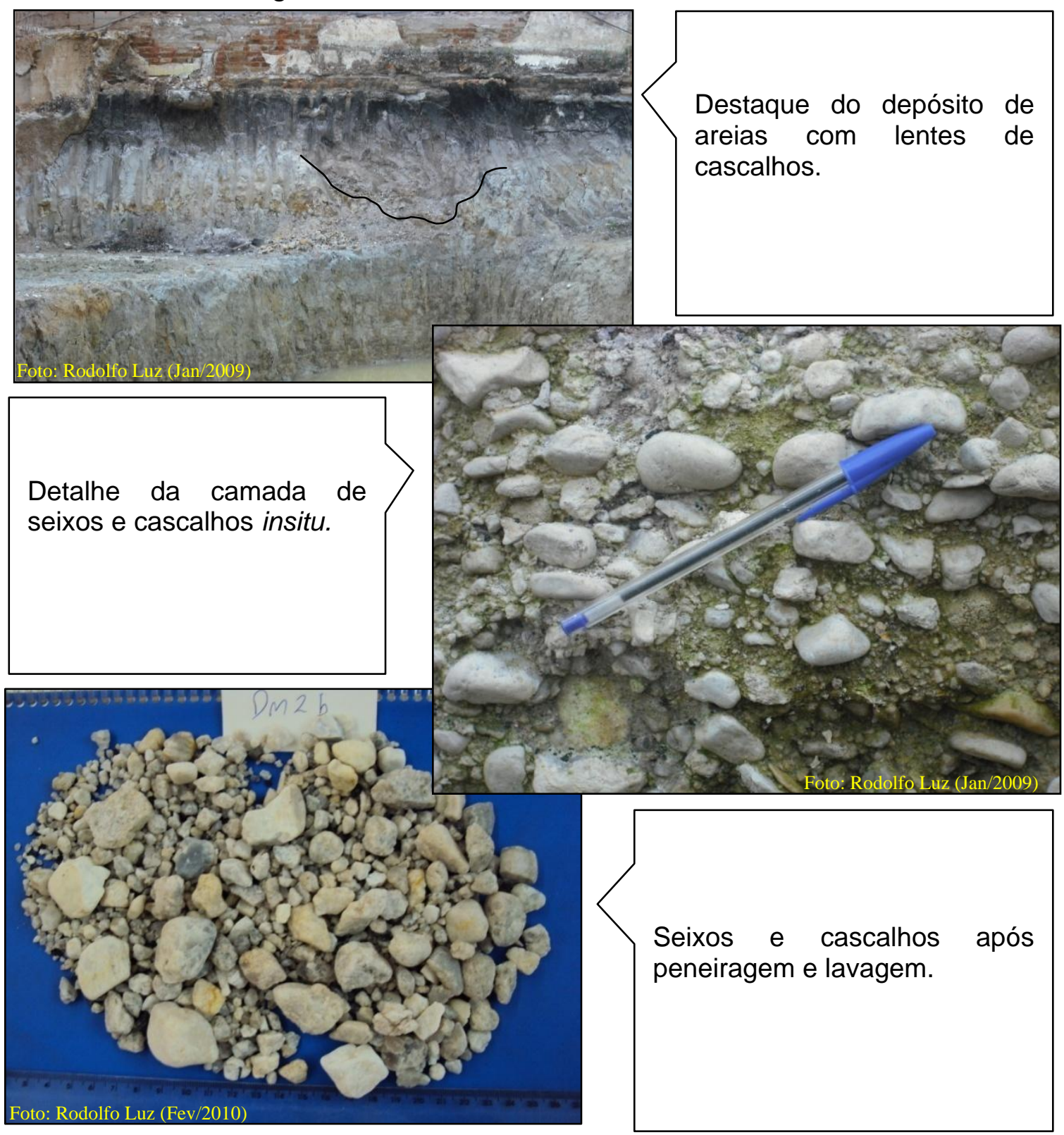




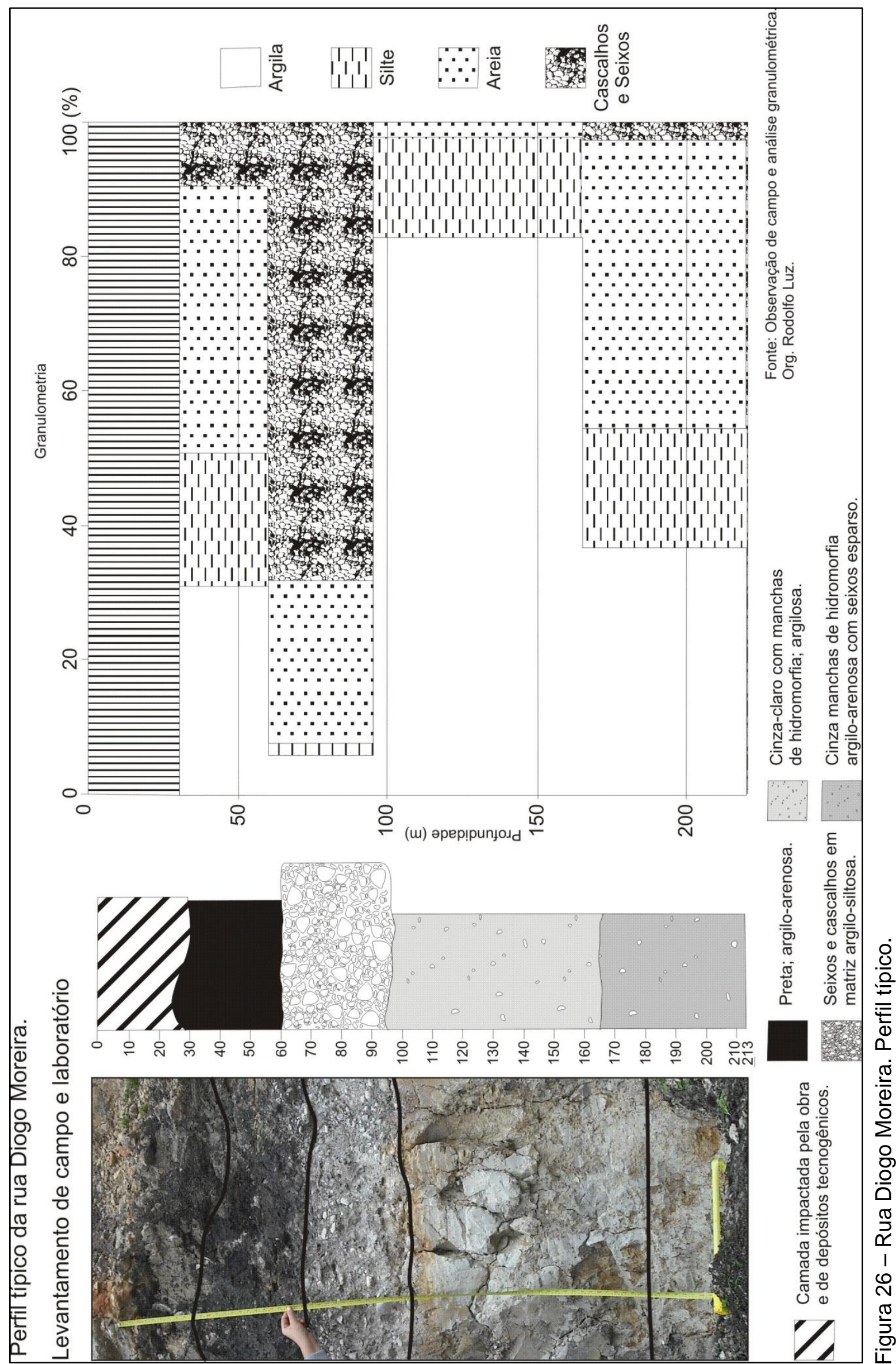




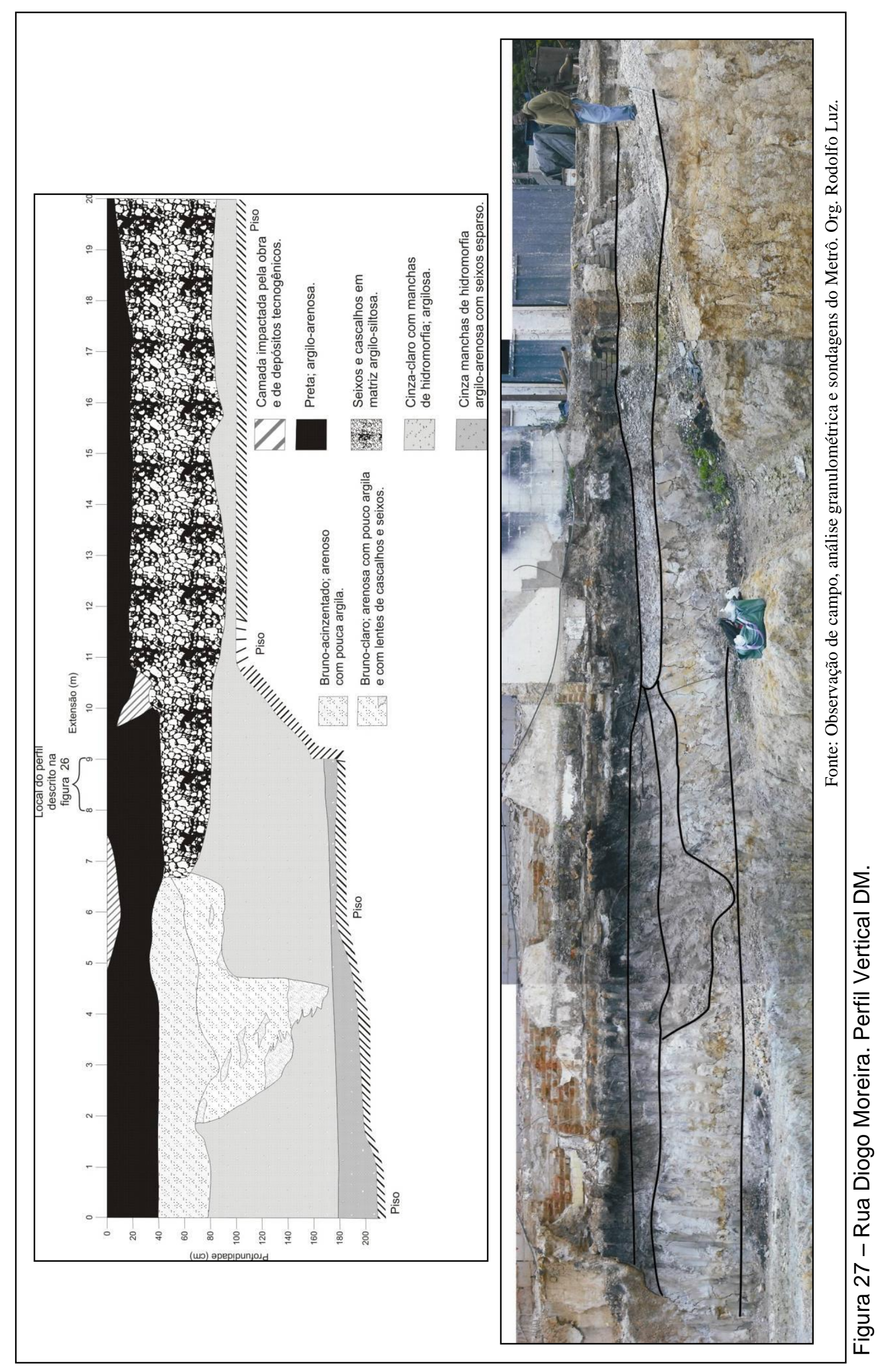




\section{Rua Seridó}

Este outro local investigado está totalmente inserido na planície de inundação, especificamente entre o canal ativo do rio Pinheiros e um meandro abandonado no bairro de Cidade Jardim. Seus materiais superficiais são apresentados nas sondagens geológicas da Figura 28, no perfil vertical da Figura 29 e nas fotos da Prancha 4.

Os sedimentos quaternários possuem em média 5 metros de espessura e estão assentados diretamente sobre o embasamento pré-cambriano, seja a rocha sã seja a rocha intemperizada. Embora haja variações locais, as sondagens geológicas mostram uma configuração estratigráfica geral da área, onde é nítida a ocorrência de sedimentos finos no topo (argila, silte e areias finas), sedimentos médios nas porções intermediárias (areias médias e grossas) e sedimentos grosseiros na base (cascalhos e seixos).

Aproximando a escala de observação, o levantamento de campo e a análise das sondagens permitiram a identificação de alguns aspectos dos materiais superficiais desta porção da planície de inundação do rio Pinheiros:

- As duas sondagens geológicas localizadas sobre um meandro abandonado são as que apresentam as maiores espessuras de depósitos tecnogênicos, cerca de 4,5 metros, e não apresentam camadas arenosas intermediárias. Além disso, são as duas únicas sondagens onde é destacada a presença de raízes nas camadas finas superiores. Isto mostra que estes meandros abandonados possivelmente estariam em terrenos mais baixos do que os da planície de inundação devido a maior espessura dos aterros e em processo de colmatação devido a presença de finos, raízes e matéria orgânica.

- A única sondagem localizada onde seria o canal ativo do rio Pinheiros (SM2) também não apresenta as camadas arenosas intermediárias, além disso, ela mostra o contato entre os sedimentos quaternários e o embasamento pré-cambriano no nível altimétrico mais inferior entre todas as sondagens, cerca de 2,62 metros abaixo da média das outras sondagens. 
- Em uma pequena área da planície de inundação há uma camada de sedimentos finos com matéria orgânica abaixo da camada de sedimentos grosseiros e acima da rocha intemperizada do embasamento. Esta estratigrafia é representada pelo Perfil Vertical SE (Figura 29). Nele vemos que a tendência geral de aumento na quantidade de sedimentos grosseiros em profundidade é interrompida por esta camada orgânica de cerca de $30 \mathrm{~cm}$ de espessura, denotando um momento de sedimentação de finos (carga em suspensão) anterior ao evento que resultou na deposição dos cascalhos e seixos que são frequentes na base da estratigrafia quaternária da planície fluvial do rio Pinheiros.

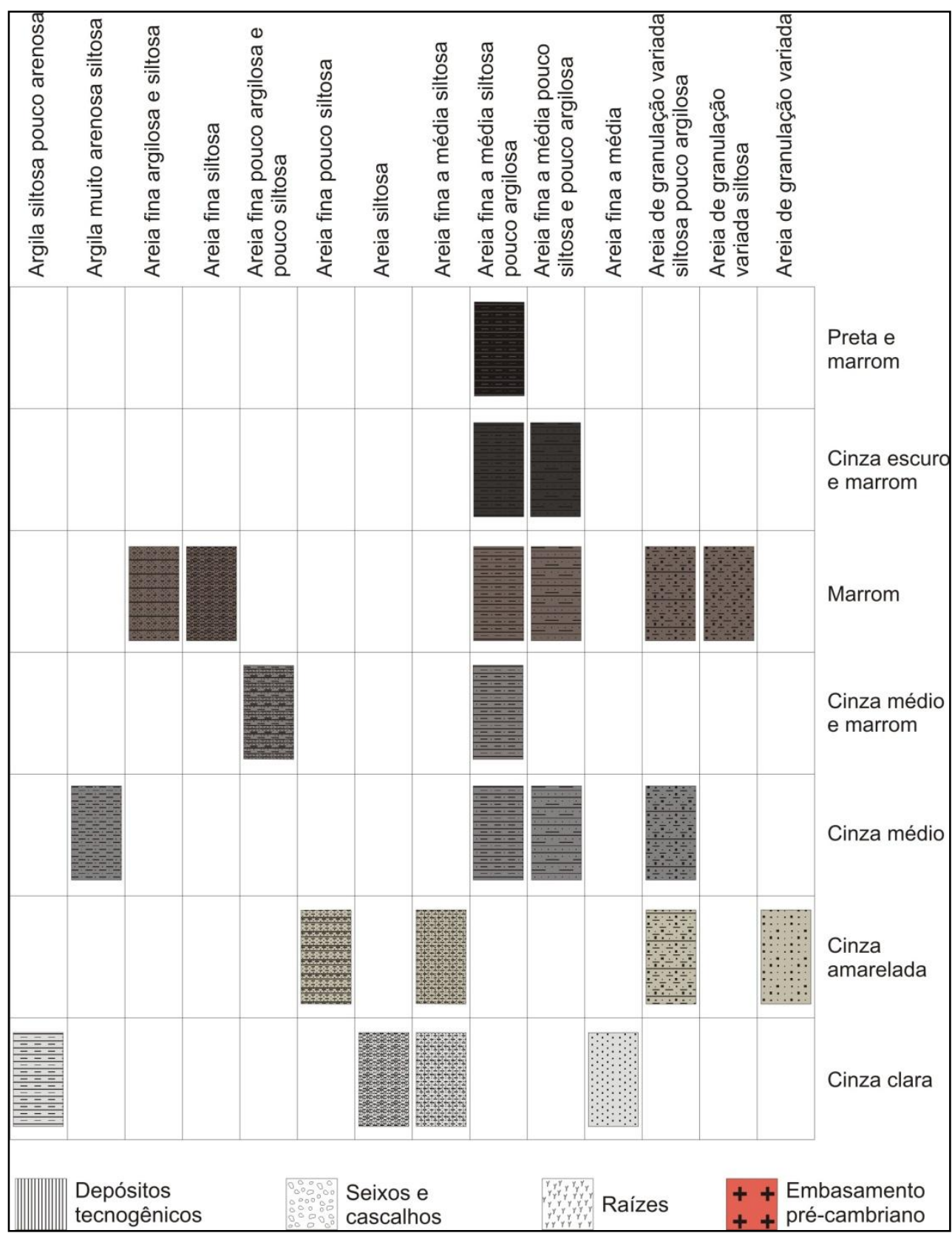

Figura 28 (legenda) - Chave de interpretação das sondagens geológicas da Rua Seridó. 


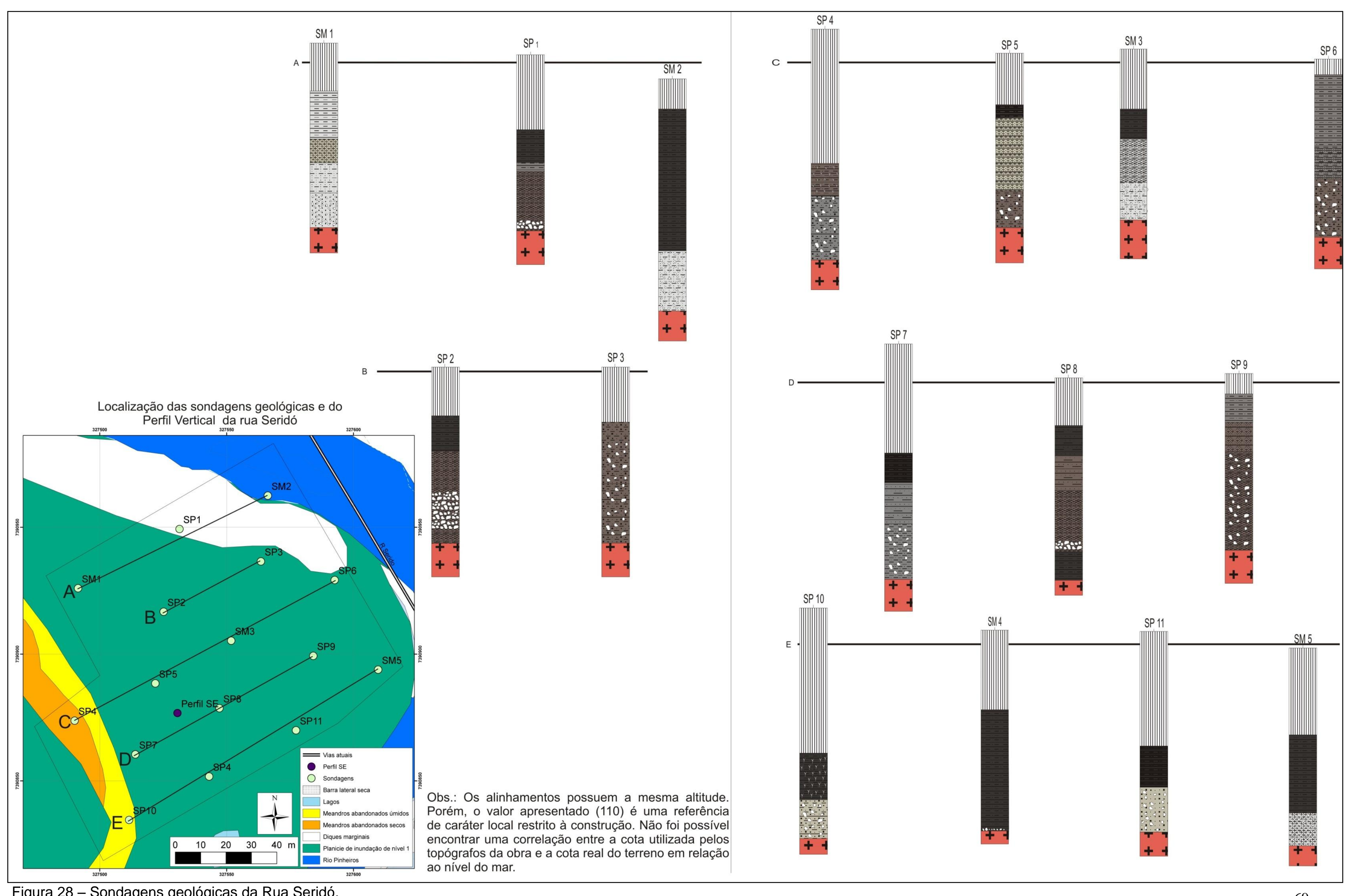




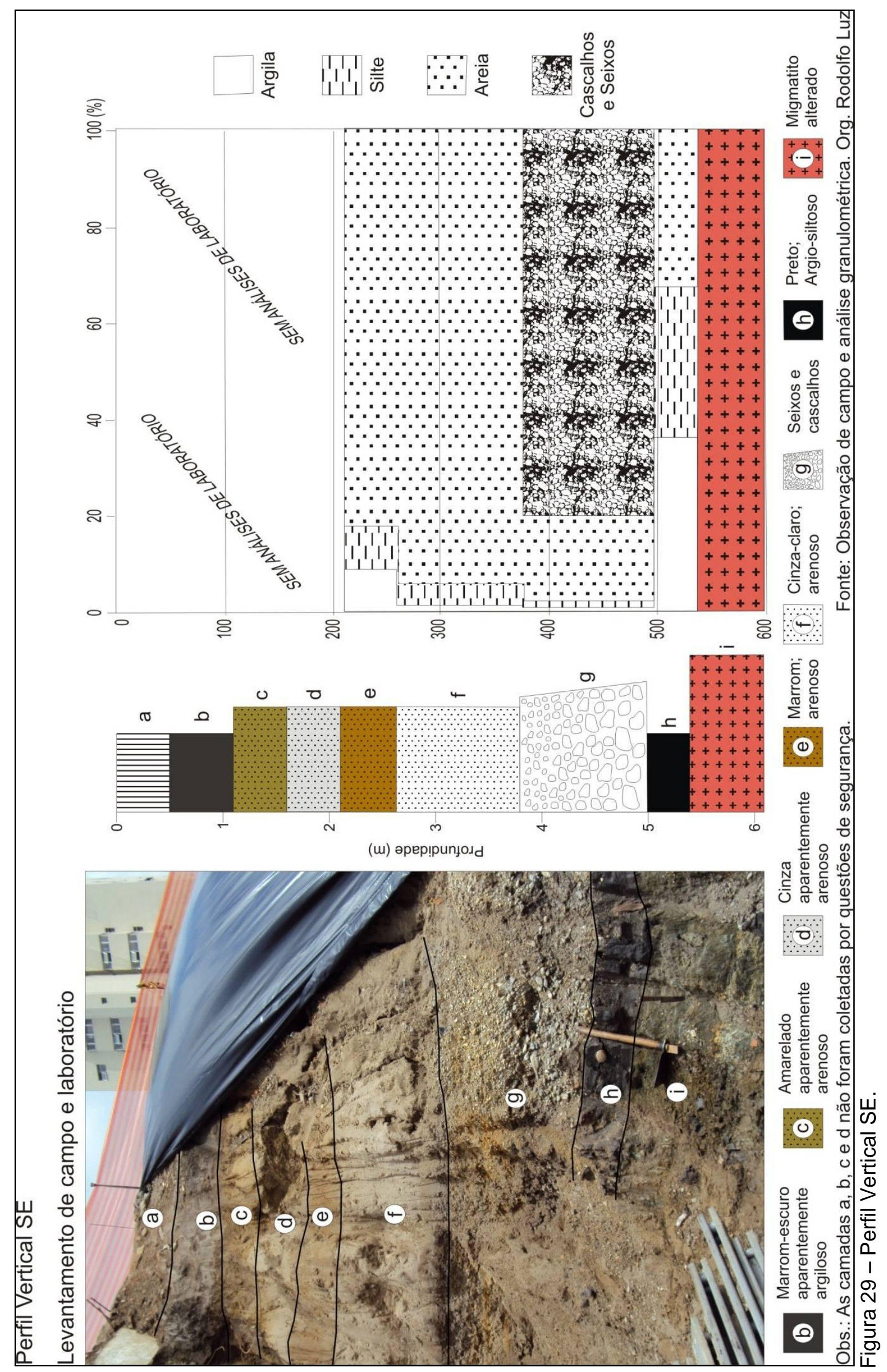


Prancha 4: Perfil Vertical SE.

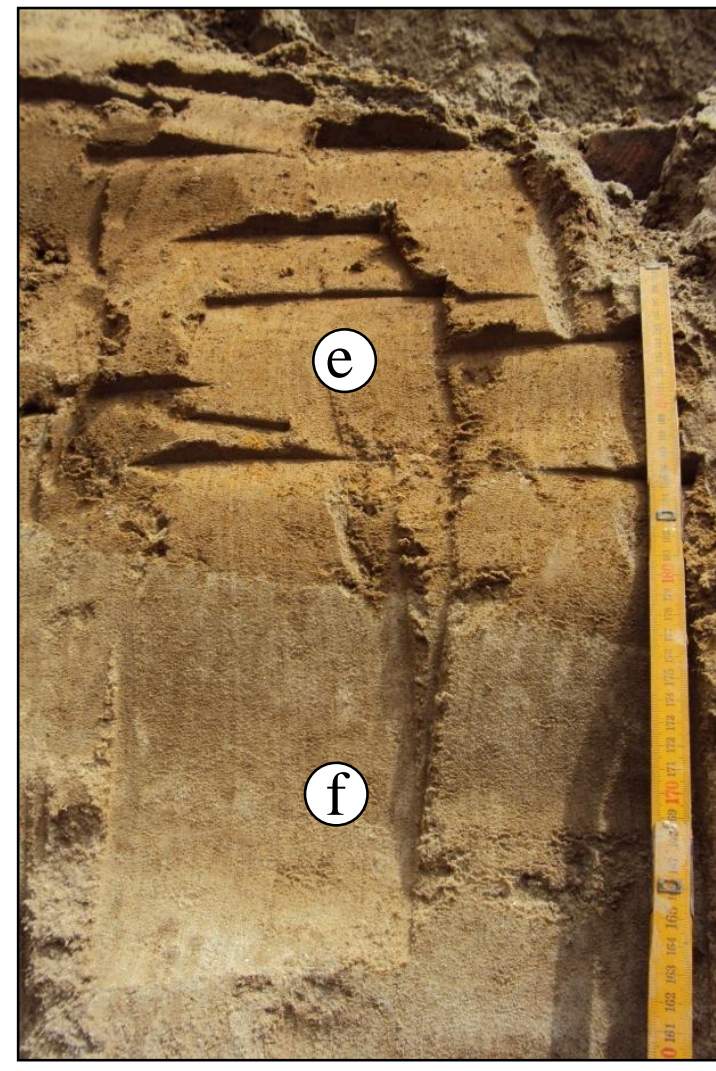

Camada orgânica entre os seixos e cascalhos fluviais e 0 embasamento pré-cambriano.

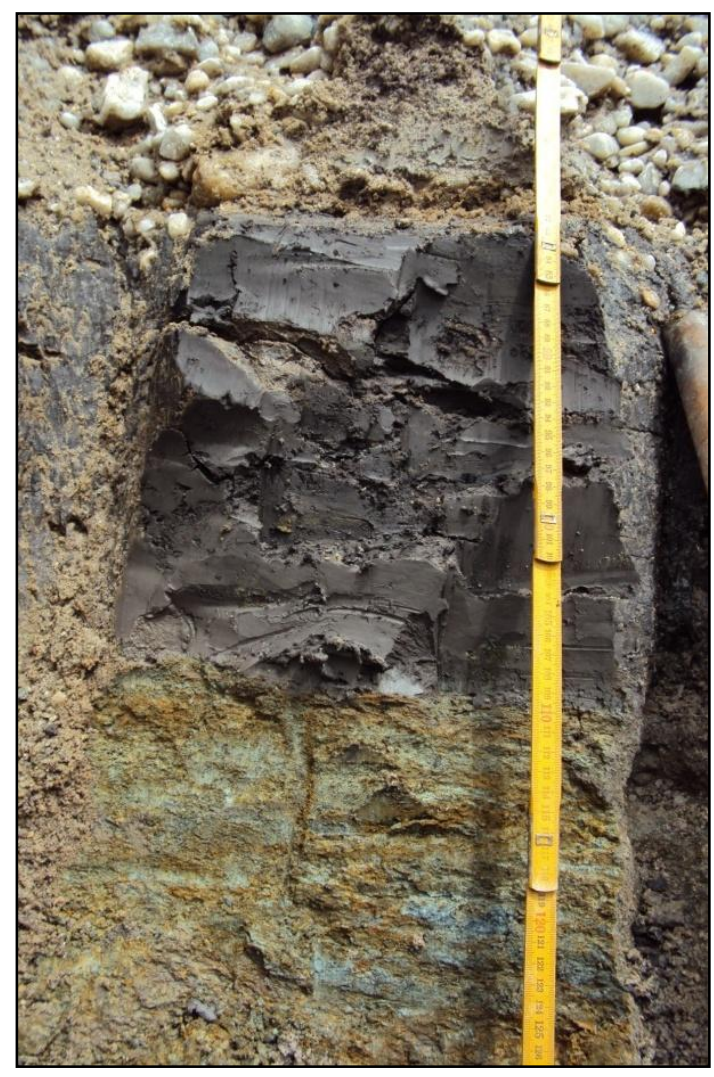

Contato entre a camada " $e$ " e a camada "f".

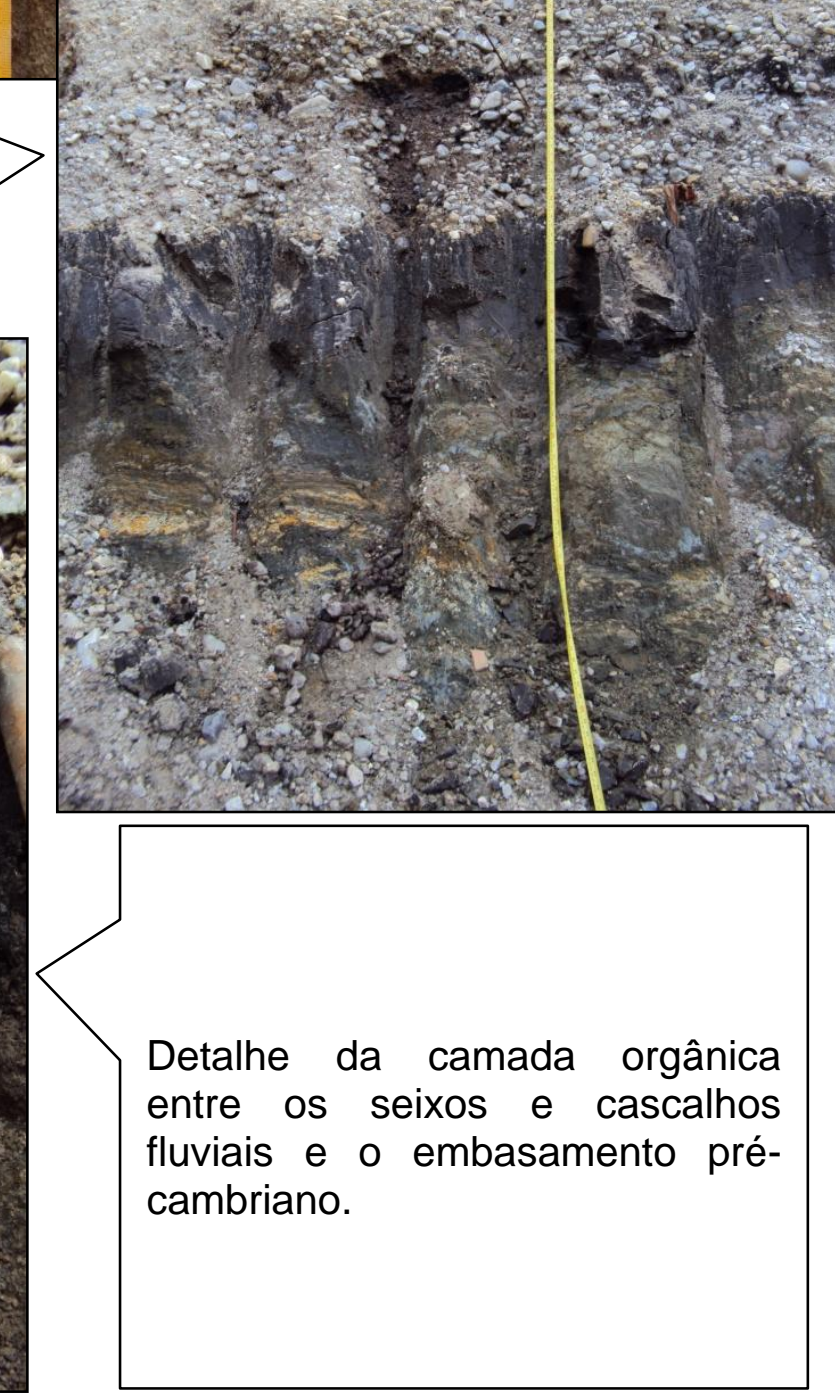




\subsection{INTERPRETAÇÕES GEOMORFOLÓGICAS}

4.2.1 Carta Geomorfológica de Detalhe da Planície Fluvial do Rio Pinheiros entre os Bairros de Pinheiros, Butantã e Cidade Jardim.

\section{Considerações Gerais}

O mapeamento revelou que as cotas das curvas de bases cartográficas não são boas referências para delimitação destas unidades, a exemplo do que foi realizado em cartas geotécnicas ou noutros mapeamentos. Por exemplo, a curva de nível de cota de 725 metros que, em determinados mapeamentos anteriores delimitaria o topo dos terraços fluviais nem sempre coincide com o limite identificado na fotointerpretação.

Num ponto específico, próximo a casa bandeirista do Butantã ${ }^{4}$, a base cartográfica apresenta meandros abandonados acima da cota de 725 metros. A fotointerpretação indica que, na realidade, esses meandros estão no mesmo nível altimétrico de todos os outros, ou seja, na planície de inundação. Portanto, o uso do material fornecido pelo levantamento do SARA BRASIL S/A (1930) para efeito de produção de conhecimento da geomorfologia original, deve se feito com cuidado, principalmente em estudos de maior detalhe.

Devido à diversidade de fotografias aéreas utilizadas, a carta morfológica apresenta diferentes níveis de detalhamento. As áreas hachuradas indicam justamente os locais não abrangidos pelas fotografias de 1933, ou seja, locais onde não foi possível detalhar a morfologia da planície fluvial (conforme capítulos 3.2.1. e 3.2.2.).

Apesar de ser centrada na morfografia, a carta morfológica também apresenta elementos dos outros três níveis da representação cartográfica geomorfológica (COLTRINARI, 1982): a morfometria é um pouco comprometida por causa de deficiências na base cartográfica e no georreferenciamento das fotografias aéreas; a morfodinâmica é apresentada principalmente em forma de texto, e não de símbolos cartográficos; como não há datações absolutas a cronologia é

\footnotetext{
${ }^{4}$ A casa bandeirista do Butantã é uma edificação do século XVIII que ainda permanece no local, tornando-se um importante ponto de referência espacial para o presente estudo.
} 
relativa, por exemplo, o canal fluvial ativo é mais recente que os meandros abandonados; os cordões marginais sub-atuais são mais recentes do que os remanescentes; a planície de inundação de nível 1 é mais recente que a de nível 2 que, por sua vez, é mais recente que os terraços fluviais.

\section{A Carta Geomorfológica de Detalhe}

A Carta Geomorfológica de Detalhe da Planície Fluvial do Rio Pinheiros entre os Bairros de Pinheiros, Butantã e Cidade Jardim é apresentada na Figura 30, e sua legenda na Tabela 2.

A área mapeada compreendeu cerca de $11 \mathrm{~km}^{2}$ da planície fluvial do rio Pinheiros e de parte de seus afluentes, sendo o rio Pirajussara o de maior expressão neste trecho. Nos terrenos relacionados aos processos do sistema vertente foi utilizada a classificação proposta por Ab'Saber (1957).

A planície fluvial é mais extensa na margem direita, onde há uma mudança em forma de rampa com os terraços de nível intermediário. Somente no extremo norte da planície é que o limite é mais abrupto, formando uma ruptura com as altas colinas e espigões secundários. Ambos os compartimentos estão situados sobre os sedimentos terciários da Bacia de São Paulo.

Já na margem esquerda ocorre uma ruptura clara entre a planície fluvial e os morros sustentados pelas rochas do embasamento pré-cambriano, sendo interrompido somente quando a planície fluvial do rio Pirajussara se confunde com a do rio Pinheiros.

A carta, originada principalmente de dados de 1933, também apresenta locais onde a ação antrópica de alto impacto já se fazia presente na região e já alterava a morfologia pré-perturbação da planície fluvial. Destacam-se nestas ações as cavas de mineração de areia, freqüentes nas margens dos canais e na planície de inundação, e os aterros das estradas que a atravessavam.

Dentro da análise geomorfológica proposta, a carta de detalhe e o perfil morfosedimentológico foram as principais fontes de dados do nível descritivo das formas no estágio pré-perturbação, principalmente numa área já bastante 
alterada pela urbanização, o que impossibilita a visualização da maioria destas formas em campo.

As informações a respeito dos materiais superficiais foram inferidas a partir da revisão bibliográfica ou definidas a partir do levantamento de campo e análises de laboratório. A correlação entre formas e materiais superficiais permitiu a análise interpretativa dos processos, o que possibilitou caracterizar cada unidade morfológica identificada (Pranchas 5 e 6):

Subsistema dos terraços:

Os terraços fluviais estão acima de 724 metros de altitude, são contínuos e extensos na margem direita, e descontínuos e pouco extensos na esquerda.

Nas áreas recobertas pelo aerolevantamento de 1933 foi possível identificar a morfologia dos limites entre os terraços fluviais e a planície de inundação. Foram então caracterizadas descontinuidades côncavas ou convexas, e detalhada a morfologia em planta desses limites, indicando as tendências de escoamento dos fluxos de água que correm por estes terrenos: fluxos concentradores no caso dos limites côncavos e; fluxos dispersores no caso dos convexos.

Próximo ao ponto de estreitamento da planície de inundação há um eixo de zona de falha (EMPLASA, 1984) (denominada de faixa de cisalhamento em mapeamento da PMSP-SVMA-SEMPLA, 2002) que atravessa transversalmente a planície fluvial do rio Pinheiros no sentido SO-NE. Segundo Hasui e Sadowski (1976) e Hasui \& Carneiro (1980), esta região vincula-se a Falha de Caucaia, e delimita blocos adernados em direção ao centro da Bacia Sedimentar de São Paulo. O bloco de Cotia apresenta menor subsidência e está a jusante, enquanto o bloco Juquitiba, de maior subsidência, está a montante.

A jusante, sobre o bloco Cotia, há terraços isolados dentro da planície de inundação em ambas as margens. Onde verificou-se que o nível desses terraços corresponde a um afloramento do embasamento rochoso optou-se por classificálo como "terraço estrutural" (caso do terraço da margem esquerda, Prancha 6), porém, o terraço da margem direita também pode ter este tipo influência, o que poderá ser verificado em estudos futuros. 


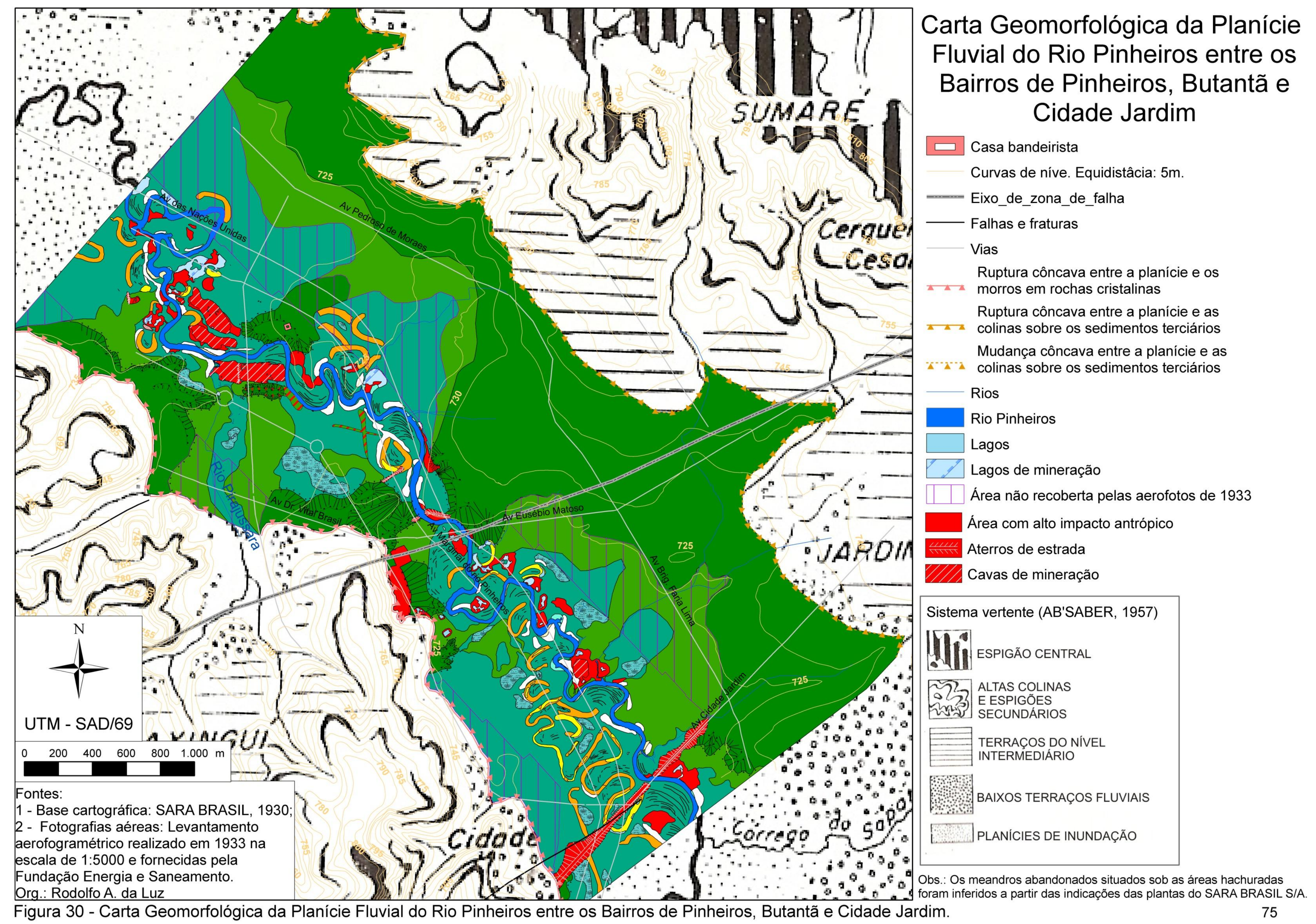


Tabela 2: Continuação da legenda da Carta Geomorfológica da Planície Fluvial do Rio Pinheiros entre os Bairros de Pinheiros, Butantã e Cidade Jardim

\begin{tabular}{|c|c|c|c|c|c|c|c|}
\hline & & \multicolumn{4}{|c|}{ Unidades Morfológicas } & Materiais Superficiais & Processos Predominantes \\
\hline & & & & Úmidas & & & \\
\hline & $\overline{\widetilde{\pi}}$ & Bar & ras Laterais & Secas & & $\begin{array}{l}\text { Areias e cascalhos depositados pelos fluxos de alta } \\
\text { competência do canal fluvial. }\end{array}$ & $\begin{array}{l}\text { fluviais mais típicos de um canal meândrico: erosão na } \\
\text { margem côncava e deposição na convexa. }\end{array}$ \\
\hline & u & & & Em colmatação & & Apresentam areias finas, silte e argila com matéria orgânica & Canais fluviais que foram abandonados por cutoff ou avulsão, \\
\hline & & Tieanarc & os Adanqonados & Colmatados & & no topo e areias grossas, cascalhos e seixos na base. & apresentando processos de colmatagem. \\
\hline & & & Diques Margi & & & Areias médias a grossas. & $\begin{array}{l}\text { Recebe sedimentos depositados durante as fases de } \\
\text { transbordamento do canal. }\end{array}$ \\
\hline & 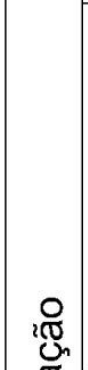 & Cordõe & s marginais & Remanescentes & & $\begin{array}{l}\text { Predomínio de areais grossas e cascalhos, com ocorrência de } \\
\text { siltes, argilas e matéria orgânica nas pequenas depressões } \\
\text { entre os cordões. }\end{array}$ & $\begin{array}{l}\text { Antigas barras laterais que foram abandonadas ou estão em } \\
\text { processo de abandono pelo canal. Apresentam vegetação e } \\
\text { incipiente desenvolvimento pedológico. Os cordões marginais } \\
\text { sub-atuais são testemunhos de processos de migração lateral do } \\
\text { canal fluvial ativo do rio Pinheiros, enquanto que os cordões } \\
\text { marginais remanescentes testemunham processos mais antigos, } \\
\text { ocorridos em canais fluviais que foram abandonados. }\end{array}$ \\
\hline 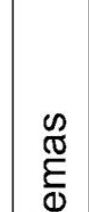 & $\begin{array}{l}\frac{0}{0} \\
\frac{5}{3} \\
\underline{\underline{D}} \\
0 \\
0 \\
0\end{array}$ & & Backswamps & & $\sqrt{E-1}$ & $\begin{array}{l}\text { Sedimentos finos (silte e argila) acumulados pelas águas } \\
\text { que são represadas após as inundações. }\end{array}$ & $\begin{array}{l}\text { Área de amortecimento das vazões de pico devido as águas } \\
\text { que são represadas após as inundações, envolvendo depósitos } \\
\text { de materiais finos por decantação, acúmulo de matéria orgânica } \\
\text { e provável gleização dos solos. }\end{array}$ \\
\hline $\begin{array}{l}\frac{\omega}{\omega} \\
\frac{0}{\partial}\end{array}$ & $\frac{\frac{O}{\frac{\pi}{T}}}{\frac{\pi}{\alpha}}$ & Níveis & Nível 1 & & & $\begin{array}{l}\text { Sedimentos com grande variedade granulométrica, porém, em } \\
\text { termos gerais, predominam areias e cascalhos na base sob } \\
\text { camadas pedológicas mais ou menos freqüentes do topo, }\end{array}$ & $\begin{array}{l}\text { Areias grossas, cascalhos e seixos advindos da } \\
\text { movimentação lateral do canal fluvial, cobertos por } \\
\text { sedimentos finos advindos da carga suspensa das }\end{array}$ \\
\hline & & & Nível 2 & & & $\begin{array}{l}\text { ocorrewm sobre as rochas pré-cambrianas intemperizadas } \\
\text { ou a sobre a Formação Itaquaquecetuba. }\end{array}$ & $\begin{array}{l}\text { Em sua base estratigráfica pode ocorrer sedimentos } \\
\text { depositados em condicões ambientais diferentes das }\end{array}$ \\
\hline & & & Elevações indifer & ciadas Nível 2 & & $\begin{array}{l}\text { Provável influência da estrutura geológica na composição dos } \\
\text { materiais devido a maior proximidade do embasamento } \\
\text { pré-cambriano. }\end{array}$ & $\begin{array}{l}\text { atuais. } \\
\text { O nível } 2 \text { recebe com menos frequência as águas das } \\
\text { inundações. }\end{array}$ \\
\hline & & & Terraço Estru & & & Rochas do embasamento pré-cambriano. & \\
\hline & & & Terraço Fluı & & & Sedimentos quaternários, solos e depósitos tecnogênicos nos & \\
\hline & & Mudanças & Mudança cônc & & & obre o embasamento pré-cambriano intemperizado, mas & Processos pedológicos e erosivos que ocorrem sobre os \\
\hline & 吕 & de Declive & Mudança conv & & $6+4$ & $\begin{array}{l}\text { tambem pode ocorrer sobre a Formaçáo Resende. } \\
\text { Os sedimentos quaternários apresentam texturas grosseiras }\end{array}$ & $\begin{array}{l}\text { sedimentos previamente depositados pela dinâmica fluvial } \\
\text { de uma planície de inundação que foi abandonada. }\end{array}$ \\
\hline & $\stackrel{\bar{\omega}}{\oplus}$ & & Retilínea & & & $\begin{array}{l}\text { na base (seixos, cascalhos e areias grossas) e finas no topo } \\
\text { (areias finas, siltes e argilas). }\end{array}$ & $\begin{array}{l}\text { Sedimentação fluvial seria menos importante, ocorrendo } \\
\text { somente durante as cheias excepcionais. }\end{array}$ \\
\hline & & em & Côncava (fluxo & concentradores) & $/ / 11$ & $\begin{array}{l}\text { Na margem direita, os setores mais distantes dos canais } \\
\text { podem estar assentados diretamente sobre a Formação }\end{array}$ & \\
\hline & & & Convexa (fluxo & dispersores) & $11 / /$ & $\begin{array}{l}\text { Resende. No limite com a planície de inundação aflora o } \\
\text { embasamento pré-cambriano intemperizado. }\end{array}$ & \\
\hline
\end{tabular}


Prancha 5: Planície fluvial do rio Pinheiros.

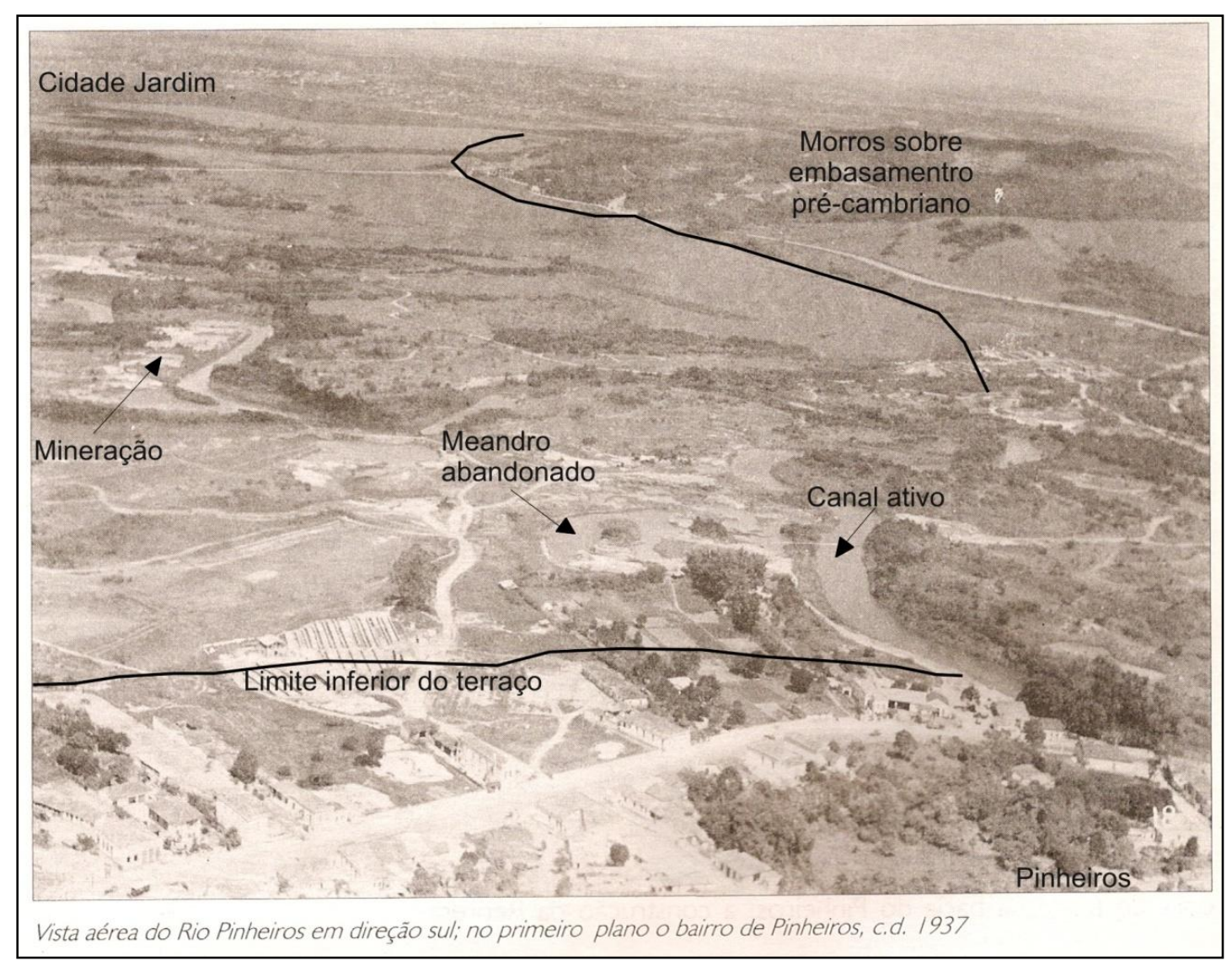

Sul da área de estudo em 1937. Destaque para algumas das unidades morfológicas identificadas. Fonte Ab'Saber (1958).

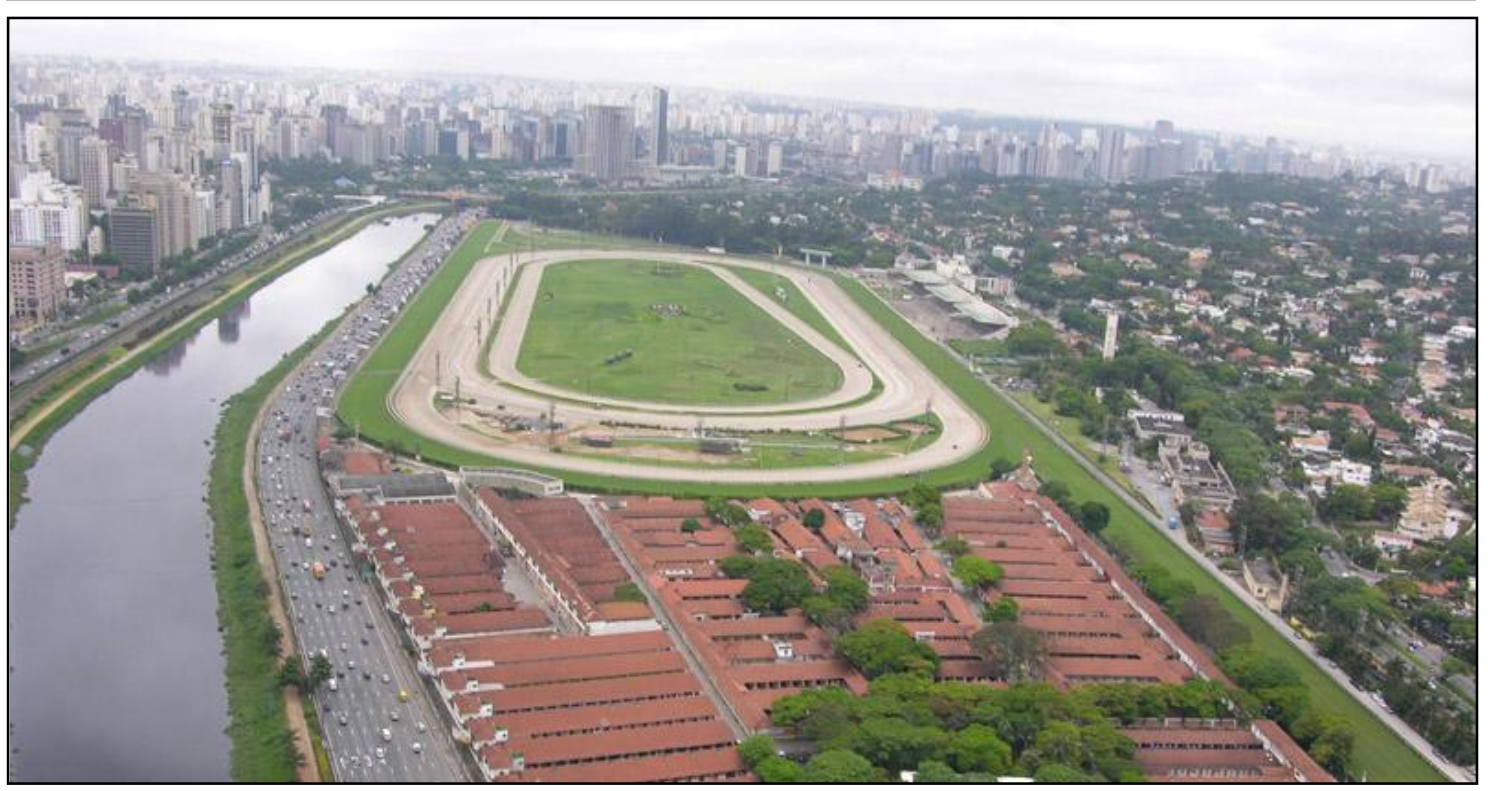

Jockey Club de São Paulo, exatamente na região do paleocanal de alta sinuosidade. Notar morros sobre embasamento pré-cambriano a direita. Fonte: (http://commons.wikimedia.org/wiki/File:Jockey Club de S\%C3\%A3o_Paulo.jpg). 
Prancha 6: Aspectos de algumas unidades morfológicas.

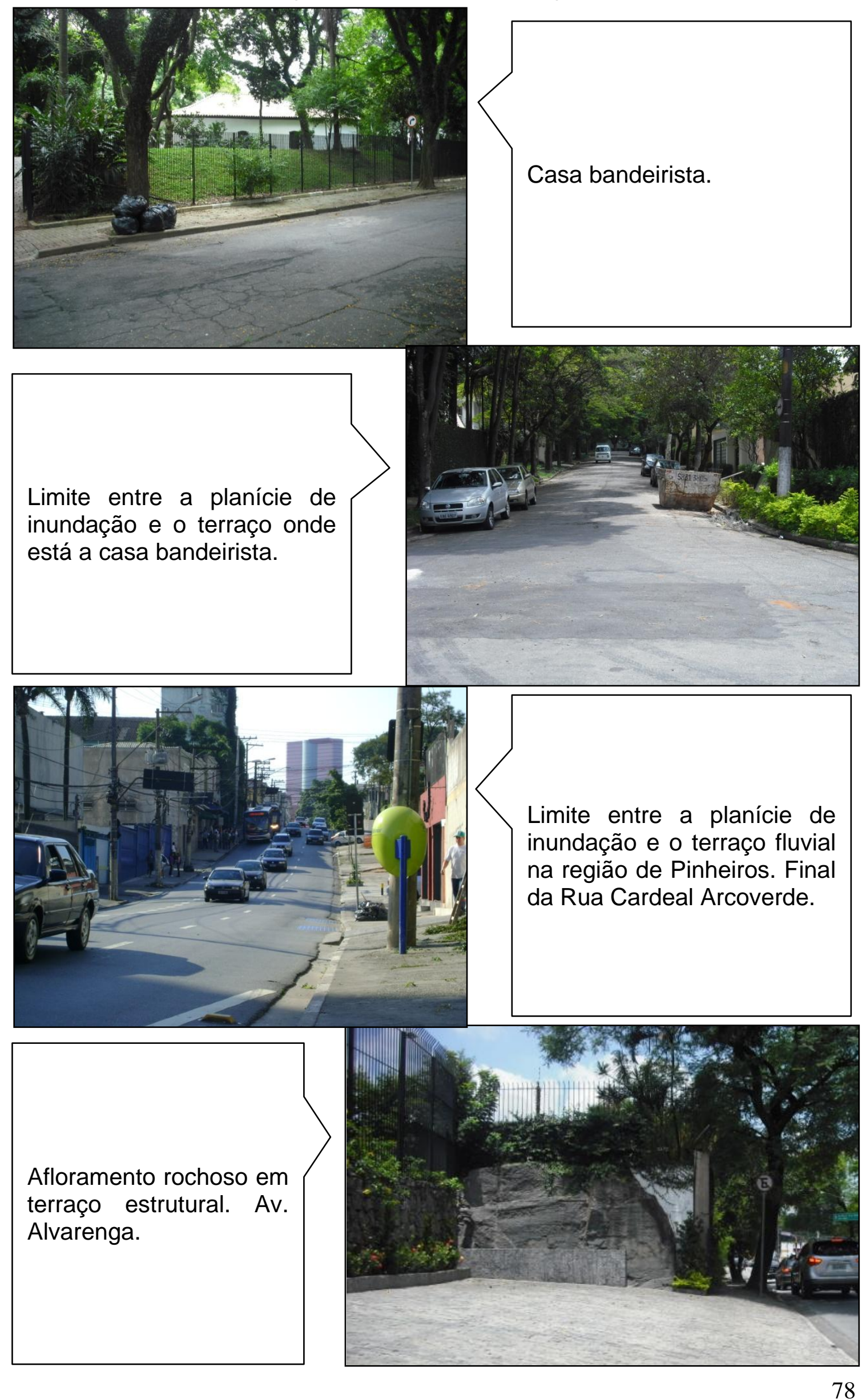


Tendo em vista os resultados apresentados para o Perfil Morfosedimentólogico Pinheiros-Butantã, os setores mais distantes dos terraços fluviais da margem direita possivelmente não apresentam sedimentos quaternários, estando assentados diretamente sobre a Formação Resende. Nestes setores, estes sedimentos que seriam os testemunhos de processos fluviais, ou nunca foram ali depositados ou foram erodidos.

Onde há sedimentos quaternários, eles formam juntamente com os solos e os depósitos tecnogênicos os 5 primeiros metros do topo da estratigrafia dos terraços fluviais (em média). Normalmente se assentam sobre o embasamento pré-cambriano intemperizado, mas podem ocorrer também sobre a Formação Resende.

No geral, os sedimentos quaternários apresentam texturas mais grosseiras na base e mais finas no topo, onde já ocorrem processos pedológicos. Nos locais mais próximos ao limite dos terraços com a planície de inundação, onde a declividade passa de $0,66 \%$ para $1 \%$, as camadas de texturas finas do topo dão lugar as mais grosseiras da base, até que, quando a declividade aumenta para $3 \%$, os sedimentos quaternários dão lugar ao embasamento précambriano intemperizado.

O afloramento do embasamento nas bordas dos terraços, em seu contato com a planície de inundação, é uma das características dos "terraços rochosos" (strath terraces) (CHRISTOFOLETTI, 1981, p 255-258; GOUDIE, 2006, p. 1041). Isto indica que, ao menos para o setor do Perfil Morfo-sedimentológico Pinheiros-Butantã, a morfogênese desses terraços está associada a uma incisão do canal do rio Pinheiros que ultrapassou os sedimentos fluviais previamente depositados e atingiu o embasamento pré-cambriano, onde foi originada a planície de inundação meândrica atual.

Aparentemente, as camadas de sedimentos quaternários grosseiros da base dos terraços possuem uma maior variedade textural interna do que as finas do topo. Enquanto as camadas da base apresentam mudanças texturais abruptas entre camadas adjacentes, as camadas do topo apresentam variações texturais mais graduais. 
Esses conjuntos sedimentares são resultados de diferentes processos morfodinâmicos. $\mathrm{Na}$ base eles refletem um ambiente instável onde processos erosivos e deposicionais associados a canais fluviais e a planície de inundação se faziam presente. $O$ topo condiz com um ambiente mais estável, onde provavelmente, no estágio pré-perturbação, predominavam processos pedológicos sobre sedimentos que se tornaram bem drenados após 0 abandono da antiga planície de inundação.

Subsistema da planície de inundação:

- Diques marginais - Ocorrem principalmente nas margens côncavas dos canais e, no geral, estão associados aos terrenos mais secos e com vegetação de maior porte do que a do entorno.

Por serem mais enxutos são os terrenos próximos ao canal mais propícios à ocupação antrópica. Nos diques marginais há vias e edificações, sendo que alguns já se encontravam bastante modificados, confundindo-se, as vezes, com aterros, principalmente nos setores próximos as áreas de mineração.

De acordo com a literatura os diques marginais geralmente contêm materiais de maior granulometria depositados durante as fases de transbordamento, quando os sedimentos mais grosseiros são depositados nestes setores mais próximos do canal fluvial devido à perda de competência do fluxo de água, que passa do canal para a planície de inundação.

A morfodinâmica nos diques marginais é caracterizada por processos sedimentares durante as fases de transbordamento do canal fluvial. Por ser um terreno relativamente mais bem drenado do que os da planície de inundação devido a sua maior altitude, incipientes processos pedológicos ocorrem quando estão a salvo das cheias, propiciando inclusive o desenvolvimento de vegetação arbórea de maior porte do que o do entorno.

- Cordões marginais. São antigas barras laterais que estão sendo progressivamente abandonadas pelo canal, tendo então morfogênese diretamente relacionada aos processos de acresção lateral. Quanto mais longe do canal mais estável se torna o cordão marginal, possibilitando inclusive o desenvolvimento de vegetação e incipiente desenvolvimento pedológico. 
Os cordões marginais sub-atuais são testemunhos de processos de migração lateral do canal fluvial ativo do rio Pinheiros, enquanto que os cordões marginais remanescentes testemunham processos mais antigos, ocorridos em canais fluviais que foram abandonados.

- Backswamps (planície de inundação isolada). Trata-se de terrenos que não são limítrofes ao canal fluvial ativo e que apresentam altitudes ligeiramente mais baixas do que as do restante da planície de inundação.

$\mathrm{Na}$ literatura revisada verificou-se que esta unidade morfológica é freqüente nos setores da planície de inundação que são mais próximos aos terraços fluviais ou ao sistema vertente, porém, não foi possível verificar se este padrão de ocorrência se faz presente na área estudada devido ao baixo grau de detalhamento do mapeamento nestes setores (áreas hachuradas não recobertas pelo aerolevantamento de 1933).

A morfodinâmica característica desses terrenos se dá pela deposição de sedimentos finos acumulados por decantação pelas águas que são represadas após as inundações, onde ocorre acúmulo de matéria orgânica e provável gleização por conta da drenagem deficiente. São consideradas áreas onde há um amortecimento das vazões de pico em um sistema fluvial meândrico, devido ao fato de estocar/armazenar parte do excedente de água fornecido por estas vazões (SANTANA, 2008, p. 206).

- Planície de inundação de nível 1. É a unidade da planície de inundação de maior extensão, onde estão localizados os meandros abandonados, diques e cordões marginais.

Os materiais superficiais apresentados pelo Perfil Morfo-sedimentológico Pinheiros-Butantã e pelos perfis da Rua Seridó mostram uma grande variedade granulométrica entre os sedimentos quaternários desta unidade, com predomínio de areias grossas e médias sobre níveis basais de cascalhos e seixos. As espessuras desses depósitos são semelhantes as dos terraços fluviais (4 a 7 metros).

A literatura indica que uma planície de inundação de um sistema fluvial meândrico possui morfogênese vinculada à movimentação lateral do canal fluvial, que 
deposita sedimentos grossos advindos dessa movimentação e que são posteriormente recobertos por sedimentos finos, advindos da carga suspensa das águas de cheia. A tendência geral de granodecrescência ascendente dos materiais observados na Rua Seridó condiz com este tipo de explicação.

Estes terrenos são mal drenados e suportam incipientes processos pedológicos de gleização.

- Planície de inundação de nível 2. São pequenas elevações que não apresentam descontinuidades abruptas com o nível 1, mas sim uma transição muito suave e, algumas vezes, de difícil delimitação.

Em alguns locais o nível 2 se configura como uma rampa suave entre o nível 1 e os terraços fluviais, principalmente na margem direita do rio.

Devido as suas semelhanças com o nível 1 e a falta de informações sobre os seus materiais, foi considerado para o nível 2 da planície de inundação os materiais e processos semelhantes aos do nível 1, pois, a princípio, a divisão destes níveis é apenas de caráter morfológico.

Porém, devido a sua posição topográfica, o nível 2 da planície de inundação apresentaria terrenos mais bem drenados que os do nível 1, com uma menor importância dos processos deposicionais por conta da menor freqüência das cheias.

É no nível 2 que se encontravam as edificações e vias da planície de inundação na década de 1930, provavelmente por serem esses terrenos mais enxutos e, consequentemente, mais propícios a ocupação antrópica.

- Elevações indiferenciadas. São elevações isoladas e de morfologia singular próximas a altitude da planície de inundação de nível 2 .

Ocorrem a jusante do ponto de estreitamento da planície de inundação associada a um eixo de zona de falha vinculado a Falha de Caucaia. Nesta região também ocorrem terraços estruturais ou de provável influência estrutural, o que indica que estas elevações podem ter morfogênese condicionada pela estrutura geológica do embasamento da planície fluvial. 


\section{Subsistema do canal:}

- Barras laterais. Tratam-se das barras de acresção lateral (point-bars), onde é possível perceber a sedimentação ativa do rio. São mais freqüentes na margem convexa do canal e correspondem as morfologias mais baixas do canal fluvial, com altitudes próximas à do próprio canal.

Sua morfogênese é vinculada aos fluxos de alta competência do canal fluvial, que depositam sedimentos grosseiros através dos processos fluviais mais típicos de um sistema meândrico, que é a erosão na margem côncava e posterior deposição na convexa.

As barras laterais classificadas como secas são as que no momento da tomada das fotografias aéreas estavam num estágio de "abandono" pelo canal fluvial, ou seja, menos submetidas as ações morfodinâmicas do canal fluvial ativo do que as barras úmidas, que se localizam praticamente dentro do canal.

- Meandros abandonados. Atingem altitudes um pouco menores que a planície de inundação de Nível 1.

A estratigrafia típica deste tipo de feição apresenta sedimentos grosseiros na base, testemunhos dos processos morfodinâmicos de quando o canal era ativo, recobertos por sedimentos finos com altos teores de matéria orgânica depositados em águas de inundação represadas após o abandono do canal.

Duas sondagens geológicas na região da Rua Seridó apresentaram este tipo de estratigrafia, tendo a camada de finos com matéria orgânica do topo de 1 a 1,5 metros de espessura e a de sedimentos grosseiros da base de 1,3 a 2,1 metros.

No Perfil Morfo-sedimentológico Pinheiros-Butantã um local associado a um meandro abandonado apresentou apenas os sedimentos grosseiros da base com cerca de 3 metros de espessura. A falta dos sedimentos finos pode estar associada: 1) ao baixo grau de detalhamento da fonte de dados original (sondagens geológicas do Metrô) que pode não ter detectado camadas pouco espessas do topo ou; 2) às intervenções antrópicas anteriores ao aterramento 
que modificaram as características dos materiais na superfície do meandro abandonado.

Os depósitos tecnogênicos são bastante espessos. Nas sondagens da Rua Seridó eles possuem entre 4,5 e 4,8 metros, enquanto que no Perfil MorfoSedimentológico Pinheiros-Butantã atingem 3 metros. Em ambos os casos os sedimentos grosseiros da base estão assentados diretamente sobre 0 embasamento pré-cambriano.

Os principais processos morfogenéticos dos meandros abandonados da área de estudo são cutoff e avulsão. Um evento de avulsão parece ter sido responsável pelo abandono de um canal com 2,83 km de extensão a montante do ponto de estreitamento da planície de inundação, na porção sul da carta na margem esquerda do rio Pinheiros.

Os meandros abandonados situados sob as áreas hachuradas foram inferidos a partir das indicações das plantas do SARA BRASIL S/A.

\subsubsection{Aspectos morfogenéticos da planície fluvial}

A análise geomorfológica da planície fluvial do rio Pinheiros na área estudada mostra que há um estreitamento da planície de inundação diretamente associado a um eixo de zona de falha vinculado a Falha de Caucaia, que delimita um bloco de menor subsidência a jusante (bloco Cotia), de um bloco de maior subsidência a montante (bloco Juquitiba) (HASUI E SADOWSKI, 1976; HASUI \& CARNEIRO, 1980).

No trecho a jusante desse eixo de zona de falha, sobre o bloco de menor subsidência (Cotia), há um terraço comprovadamente estrutural e elevações indiferenciadas e terraços isoladas que podem estar refletindo em suas morfologias aspectos estruturais desta configuração geológica regional.

Este contato entre dois blocos com diferentes amplitudes de subsidência, que coincide com o local onde ocorre o estreitamento da planície de inundação, demarca um ponto onde a planície fluvial do rio Pinheiros na área estudada pode ser subdividida em dois compartimentos: 
1 - À montante deste ponto a planície de inundação é ampla e tem as suas unidades mais típicas bem desenvolvidas e de fácil reconhecimento, como os meandros abandonados, os cordões marginais $e$ as backswamps. Além disso, não apresenta terraços estruturais e outras elevações isoladas. Os mapas geológicos da área não indicam afloramentos do embasamento pré-cambriano neste compartimento, além disso, a descrição dos materiais da Rua Seridó, apesar de não amostrar satisfatoriamente todo o compartimento, não indica nenhum ponto onde 0 embasamento pré-cambriano se aproxima da superfície, estando este sempre abaixo dos 5 metros de profundidade.

2 - À jusante a planície de inundação é truncada por terraços e elevações isoladas de provável influência estrutural. Além disso, diminui a quantidade das unidades típicas de uma planície de inundação, que ocorrem confinadas entre essas elevações. A estrutura geológica também é outra, pois o mapa geológico apresenta uma maior quantidade de falhas no entorno e, como também foi visto no Perfil Morfo-Sedimentológico Pinheiros-Butantã, locais de afloramento do embasamento pré-cambriano.

Estas morfologias com possíveis vínculos morfogenéticos relacionados à estrutura geológica indicam que a maior proximidade do embasamento précambriano nos terrenos sobre o bloco Cotia, podem estar impondo uma maior restrição ao desenvolvimento de processos fluviais.

Portanto, a estrutura geológica relacionada ao contato entre os blocos Cotia e Juquitiba pode ter influenciado no nível de base local, modificando a configuração morfológica da planície fluvial a montante, principalmente no que se refere ao subsistema do canal, que é o mais dinâmico dentro de um sistema fluvial.

Desta forma, foram identificadas algumas diferenças morfológicas entre o canal fluvial ativo do rio Pinheiros e um paleocanal abandonado a montante do ponto de estreitamento da planície de inundação. Estas diferenças foram quantificadas através da geometria de cada canal, mais especificamente, da largura e do índice de sinuosidade (Tabela 3) (Figura 21). 
Tabela 3 - Índice de sinuosidade e largura do canal fluvial ativo do rio Pinheiros e do paleocanal a montante do ponto de estreitamento da planície de inundação.

\begin{tabular}{|c|c|c|}
\hline & Largura média (metros) & Índice de sinuosidade (Is) \\
\hline Canal ativo & 25,23 & 2,05 \\
\hline Paleocanal & 20,00 & 3,20 \\
\hline Diferença & $-35,93 \%$ & $+26,15 \%$ \\
\hline
\end{tabular}

O próprio canal fluvial ativo é um pouco menos largo e mais sinuoso a montante do ponto de estreitamento (Tabela 4) (Figura 21).

Tabela 4 - Índice de sinuosidade e largura do canal fluvial ativo do rio Pinheiros a jusante e a montante do ponto de estreitamento da planície de inundação.

\begin{tabular}{|c|c|c|}
\hline Canal fluvial ativo & Largura média (metros) & Índice de sinuosidade (Is) \\
\hline$\dot{A}$ jusante & 28,06 & 1,73 \\
\hline$\dot{A}$ montante & 25,23 & 2,05 \\
\hline
\end{tabular}

Os maiores índices de sinuosidade do setor de montante, tanto do paleocanal como do canal ativo, quando comparados ao setor de jusante, revelam provavelmente, mudança de declividade do perfil longitudinal e na carga sedimentar do canal. Estas mudanças podem ser decorrentes tanto de alterações no aporte sedimentar da bacia hidrográfica quanto de imposições de caráter estrutural (OUCHI, 1985; SCHUMM, 1963; SHUMM et al., 2002), ou, ainda, devido aos dois tipos de eventos agindo em conjunto.

A carta geomorfológica mostra que, em algum momento do Pleistoceno Superior ou do Holoceno, o canal do rio Pinheiros apresentou menores larguras e maiores sinuosidades a montante do ponto de estreitamento da planície de inundação aqui identificado (Figura 31).

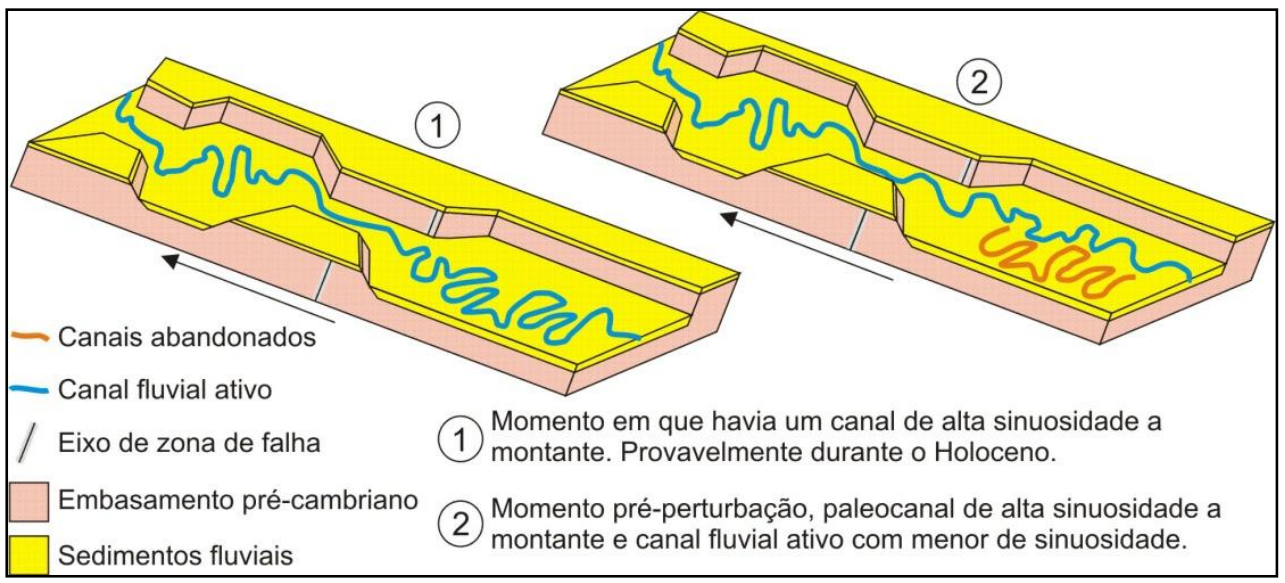

Figura 31 - Croquis esquemáticos da mudança de sinuosidade em parte do canal do rio Pinheiros ocorrida no Quaternário. 
Este estudo aponta para a interpretação de que estas discrepâncias morfológicas refletem condicionamentos estruturais, principalmente de caráter litológico do embasamento subjacente e por vezes aflorante, pois este ponto de estreitamento da planície de inundação está numa zona de contato entre blocos delimitados por falhas tectônicas, e que sofreram adernamentos com diferentes graus de subsidência.

Pequenas diferenças morfológicas no próprio canal fluvial ativo (Tabela 4) podem ser reflexos destes condicionantes estruturais.

Outro indicativo morfogenético que o estudo mostra é a respeito dos materiais superficiais que compõem a planície fluvial. A espessura média de sedimentos quaternários fluviais é de 5 metros e a sua composição estratigráfica mais típica é a seguinte: sedimentos finos no topo (areias finas, silte e argila), areias médias a grossas nas porções intermediárias e seixos e cascalhos na base.

Santos (1958) e Carvalho (2006) apresentam a profundidade média do rio Tietê na região de São Paulo em seu estágio pré-perturbação, que é de 2 a 3 metros. O rio Pinheiros devia apresentar medidas semelhantes, pois, além de ser um afluente do Tietê possui o mesmo sistema fluvial (sistema meândrico).

Portanto, devido a profundidade dos depósitos de cascalhos e seixos, que ocorre geralmente abaixo dos 3 metros de profundidade, estes sedimentos não podem ter sido depositados pelo sistema fluvial que o rio Pinheiros apresentava no momento pré-perturbação. Provavelmente, em muitos pontos o leito do rio poderia ser o próprio nível de cascalhos e seixos.

Sendo assim, os sedimentos grosseiros da base da planície de inundação do rio Pinheiros evidenciam um momento onde o canal fluvial possuía maior competência de fluxo, um canal que provavelmente não era meândrico, pois esse sistema fluvial é associado a canais com carga em suspensão e dissolvida, e não a canais com cargas de leito (como é o caso dos cascalhos e seixos). 
Este momento teria sido anterior ao estágio pré-perturbação. A bibliografia nos mostra que o sistema fluvial associado a este tipo de carga é o entrelaçado, que pode ter sido então o sistema responsável pelo depósito dos cascalhos e seixos comuns na base estratigráfica da planície de inundação do rio Pinheiros.

Em algum momento do Pleistoceno Superior ou do próprio Holoceno este sistema se transformou, tornando-se meândrico, demarcando o início da formação da planície de inundação atual até a perturbação antrópica. Ao que tudo indica, essa mudança está na faixa das dezenas de milhares de anos.

A granodecrescência ascendente, apresentada pelos sedimentos da planície de inundação do rio Pinheiros, é uma das características básicas do modelo faciológico de sedimentação em ambientes fluviais meândricos, e é resultado da migração lateral do canal e evidencia um ciclo de deposição fluvial meândrica do rio Pinheiros (WALKER, 1983; MIALL, 1996; KNIGHTON, 1998).

Os processos morfogenéticos da planície de inundação meândrica no estágio pré-perturbação podem ter sido responsáveis pela granodecrescência ascendente identificada. Sobre a camada de cascalhos e seixos depositados pelo sistema fluvial da fase anterior teria ocorrido a deposição uma fina camada de cascalhos e areias grossas transportadas no leito do canal meândrico. Sobre esta camada ocorrem os sedimentos arenosos que podem ser testemunhos de barras de meandro (acresção lateral). No topo ocorrem as areias finas, siltes e argilas, depositadas por acresção vertical.

Por fim, a configuração escalonada dos terraços fluviais pode ser um indicativo morfogenético de que, ao longo do tempo, o sistema fluvial apresentou uma maior tendência ao entalhamento do canal (CHRISTOFOLETTI, 1981, p. 255). A planície de inundação de nível 2 pode se tratar de um estágio mais recente de entalhamento, e se tornaria um terraço caso essa tendência não tivesse sido interrompida pelos agentes geomorfológicos antropogênicos.

Estas são possibilidades indicadas pela pesquisa, porém, mais dados são necessários para aprofundar o conhecimento morfogenético da planície fluvial do rio Pinheiros, como por exemplo, datações absolutas. 


\section{CONSIDERAÇÕES FINAIS}

Podemos considerar que o principal objetivo da presente pesquisa foi atingido, uma vez que a descrição, a caracterização e o mapeamento da morfologia préperturbação e dos materiais da planície fluvial, tornou possível a interpretação de processos geomorfológicos atuantes no sistema antes das intervenções antrópicas de alto impacto.

A análise geomorfológica de parte da planície fluvial do rio Pinheiros permitiu a identificação de uma provável sequência de eventos geomorfológicos atuantes no setor estudado durante o Pleistoceno Superior e o Holoceno. Alterações na geometria do canal e na configuração geral dos sedimentos fluviais foram os principais elementos utilizados na identificação dessas mudanças.

Aspectos relacionados à estrutura geológica regional também foram identificados. Este tipo de influência estrutural na planície fluvial do rio Pinheiros parece ocorrer regionalmente, e pode estar refletida nas inflexões do canal nas proximidades de Santo Amaro e da Cidade Jardim.

A pesquisa mostrou também que as sondagens geológicas devem ser utilizadas cuidadosamente em análises geomorfológicas, não tendo se mostrado apropriadas para estudos de detalhe. Isso, somado a pouca quantidade de amostras dos materiais superficiais da planície fluvial que foram analisadas, ainda não permite que as afirmações morfogenéticas aqui realizadas sejam categóricas, ao menos aquelas que são centradas na análise dos materiais.

As interpretações morfodinâmicas e morfogenéticas aqui realizadas poderão contribuir para o prosseguimento dos estudos e para a análise de novos registros sobre os materiais superficiais da planície. Estes registros também poderão subsidiar a complementação da descrição dos materiais que compõem cada unidade morfológica.

O entendimento da arquitetura fluvial da planície aponta os locais onde há descontinuidades verticais e laterais entre os pacotes sedimentares, auxiliando na revisão dos conhecimentos prévios sobre a estrutura geológica e as protuberâncias cristalinas basais da planície do Pinheiros. As características e 
contatos dos depósitos tecnogênicos, dos sedimentos quaternários, dos sedimentos terciários e do embasamento pré-cambriano e seus diferentes graus de intemperismo, podem ter implicações geotécnicas significativas, como por exemplo, no caso do colapso do poço da Estação Pinheiros do Metrô ocorrido em janeiro de 2007 (AB'SABER, 2007, p. 98).

Um estudo de geomorfologia fluvial como este pode subsidiar análises paleogeográficas direcionadas à interpretação de registros de mudanças ambientais em sistemas naturais, e se configura com a base para a realização deste tipo de análise em sistemas antrópicos. O entendimento do sistema geomorfológico da planície fluvial do rio Pinheiros em seu estágio préperturbação gerou resultados e produtos que poderão ser utilizados no planejamento físico-territorial regional, tendo em vista as constantes e drásticas modificações que nela ocorreram e que ainda ocorrem (VERSTAPPEN, 1983; GREGORY, 2002).

Desde a década de 1940 o rio Pinheiros e sua várzea não são mais partes integrantes do cotidiano paulistano (AB'SABER, 1957, p. 153; SANTOS, 1958, p. 46). A retificação do canal e posterior uso da planície de inundação como um espaço de circulação de mercadorias da cidade fez com que ele não se constitua mais como um local de vivência e moradia para a maioria da população que reside ou trabalha nas proximidades (OSEKI, 2000, p. 172), "os habitantes já não dão conta de sua existência" e o rio só é percebido quando ocorrem as enchentes (SEABRA, 1987, p. 66). Logicamente que o retorno às condições ambientais antigas é impossível. Porém, ainda é possível o rio tornar-se novamente parte do cotidiano dos paulistanos de forma positiva. 


\section{BIBLIOGRAFIA}

AB'SABER, A. Os terraços fluviais da região de São Paulo. Anuário da Fac. de Fil. Sedes Sapientiae da PUC de São Paulo, 1952-1953, São Paulo, 1953. p. 86-104.

- Geomorfologia do sítio urbano de São Paulo. Cotia-SP: Ateliê Editoral, (Edição Fac-Similar 50 anos editada em 2007), 1957. 349p.

. O sítio urbano de São Paulo. In: AZEVEDO, A. de. A Cidade de São

Paulo. São Paulo: Companhia Editora Nacional, v. 1, 1958. p. 169-241.

A planície do Tietê no planalto Paulistano. Geomorfologia. Instituto de Geografia-USP, São Paulo, n. 57, 1978. p. 1-24,

A estrutura da planície do Pinheiros: a Geologia da região do Butantã, em São Paulo, e o desastre recente nas obras do Metrô. Scientific American Brasil. Observatório, p. 98, mar/2007.

ALMEIDA, F. F. M. de. O planalto Paulistano. In: AZEVEDO, A. A Cidade de São Paulo. São Paulo: Companhia Editora Nacional, v. 1, 1958. p. 113-168.

. Fundamentos geológicos do relevo paulista. Boletim IGG. São Paulo: Instituto Geográfico e Geológico, o41. 1964. p. 168-274.

; RICCOMINI, C.; DEHIRA, L. K.; CAMPANHA, G. A. C. Tectônica da Formação Itaquaquecetuba na Grande São Paulo. In: Congresso Brasileiro de Geologia, 33, 1984, São Paulo. Anais... Rio de Janeiro. SBG, v. 4, 1984. p. 17941808.

ARAI, M. \& YAMAMOTO, J. K. Datação da Formação Itaquaquecetuba. 4ำ Simpósio de Geologia do Sudeste, 1994, São Pedro-SP. Anais... São PedroSP, 1995. p. 84. 
BATISTA, C. C. Conversa cartográfica: Processo de expansão urbana na metrópole paulistana e unidades geomorfológicas de média escala. Trabalho de Graduação Individual em Geografia - Departamento de Geografia - FFLCH - USP. São Paulo, 2003.

BIGARELLA, J. J. Variações climáticas no Quaternário Superior do Brasil e sua datação radiométrica pelo método do Carbono 14. Paleoclimas. Instituto de Geografia - USP, n. 1, São Paulo, 1971. p. 1-22.

BRIDGE, J. S. Rivers and Floodplains: Forms, Processes, and Sedimentary Record. Oxford: Blackwell Science Ltd., 2003. 504 p.

CAMARGO, O. A. de; MONIZ, A. C.; JORGE, J. A.; VALADARES, J. M. A. S. Métodos de análise química, mineralógica e física de solos do Instituto Agronômico de Campinas. Campinas: Instituto Agronômico. Boletim técnico do instituto agronômico, n. 106, 1986. 94 p.

CARVALHO, D. L. R. de. Indicadores geomorfológicos de mudanças ambientais no sistema fluvial do Alto Tietê (município de São Paulo): pesquisa documental. 2006. 2v. + anexos. Dissertação (Mestrado em Geografia Física) - Departamento de Geografia - FFLCH - USP. São Paulo, 2006.

CHRISTOFOLETTI, A. Geomorfologia. São Paulo: Edgar Blucher. 1974. 149p.

. Geomorfologia fluvial. São Paulo: Edgar Blucher. 1981. 313p.

COIMBRA, A. M.; RICCOMINI, C.; MELO, M. S. de. A Formação Itaquaquecetuba: evidências de tectonismo no Quaternário paulista. In: Atas do $4^{\circ}$ Simpósio Regional de Geologia. SBG-SP. São Paulo, 1983. p. 253266. 
COLTRINARI, L. Um exemplo de carta geomorfológica de detalhe: a carta do médio vale do rio Parateí, SP. Revista do Departamento de Geografia, n.1, DG-FFLCH-USP, São Paulo, 1982. p. 55-63.

. Cartas geomorfológicas. Orientação, n.5, IGEOG-USP, São Paulo, 1984. p. 96-99.

COULTARD, J. P.; PELLERIN, J.; AGUIAR, M. B.; COLTRINARI, L. Carta do modelado e das formações superficiais do médio vale do Parateí, SP. Sedimentologia e Pedologia. Instituto de Geografia - USP, n. 9, São Paulo, 1978. $35 \mathrm{p}$.

COUTINHO, J. M. V. Petrologia do Pré-Cambriano de São Paulo e arredores.

Boletim IG no 3. São Paulo: IG-USP, 1972. Pg. 5-99.

CUNHA, S. B. Geomorfologia fluvial. In: GUERRA, A T. \& CUNHA, S. B. Geomorfologia: uma atualização de bases e conceitos. Rio de Janeiro: Bertrand Brasil, 1994. p. 211-252.

DACKOMBE, R. V. \& GARDINER, V. Geomorphological field manual. London: George Allen \& Unwin, 1983. 254 p.

DAVID, L. \& SZABO, J. (Eds.). Book review: Anthropogenic Geomorphology. Applied ecology and environmental research, n. 6, v. 3, Budapest, 2008. p. 159.

ESTAIANO, J. C. Impactos da mineração de areia em planícies fluviais meândricas da bacia hidrográfica do Alto Tietê: o caso do rio Embu-Guaçu, São Paulo - SP. 2007. 185f. Dissertação (Mestrado em Geografia Física). Departamento de Geografia - FFLCH - USP. São Paulo, 2007.

FITTIPALDI, F. C. Primeira ocorrência de briófitas na Bacia de São Paulo (Cenozóico). Revista do Instituto Geológico, n. 23, v. 2, 2002. p. 19-22. 
\& SIMÕES, M. G. Estado atual do conhecimento sobre a Paleontologia da Bacia de São Paulo. In: Workshop geologia da Bacia de São Paulo. São Paulo. Coletânea das comunicações... São Paulo, IGUSP/SBG, 1989. p. 3734.

GOUDIE, A. Encyclopedia of Geomorphology. London e New York: Taylor \& Francis e-library, 2ª Ed., 2006. 1156 p.

GREGORY, K. J. The nature of Physical Geography. London: Edward Arnold, 1985. 259 p.

. Urban channel adjustments in a management context: an Australian example. Environmental Management, n. 5, v. 29. 2002. p. 620-633.

GUERRA, A. T. Dicionário geológico-geomorfológico. Rio de Janeiro: IBGE, 6⿳⺈ ed., 1980.446 p.

HART, M. G. Geomorphology pure and applied. London: George Allen \& Unwin, 1986. 228p.

HASUI, Y.; CARNEIRO, C. D. R.; COIMBRA, A. M. The Ribeira folded belt. Revista Brasileira de Geociências, v. 5, 1975. p. 257-266.

\& SADOWSKY, G. R. Evolução geológica do precambriano na região sudeste do Estado de São Paulo. Revista Brasileira de Geociências, v. 6, 1976. p. $182-200$.

\& CARNEIRO, C. D. R.. Origem e evolução da Bacia Sedimentar de São Paulo. In: Aspectos geológicos e geotécnicos da bacia sedimentar de São Paulo. (Mesa redonda) Associação Brasileira de Geologia de Engenharia (ABGE) / Sociedade Brasileira de Geologia (SBG). São Paulo: Publicação especial, 1980. p. 5-13. 
HOOKE, R. L. On the history of humans as geomorphic agents. Geology, n. 9, v. 28,2000 . p. $843-846$.

HOUBEN, P. Geomorphological facies reconstruction of Late Quaternary alluvia by application of fluvial architecture concepts. Geomorphology, n. 86, 2007. p. 97-114.

JUNQUEIRA, C. B. Camadas cruzadas de areias, gravas e cascalhos fluviais do Vale do Rio Pinheiros ("Campus" da Cidade Universitária, S.P). Geomorfologia. Notas Prévias. Instituto de Geografia - USP, São Paulo, n. 10, 1969. p. 7-9.

KIEHL, E. J. Manual de Edafologia. São Paulo: Ed. Agronômica Ceres, 1979. p. 76-134.

KNIGHTON, D. Fluvial forms and processes: a new perspective. London, New York: Arnold. 1998. 383p.

KRAUS, M. J. \& BOWN, T. M. Paleosols and time resolution in alluvial stratigraphy. In: WRIGHT, V. P. (Ed.) Paleosols their recognition and interpretation. Oxford and Boston: Blackwell Scientific Publications, 1986. p. 180-207.

LATRUBESSE, E. M; et al. Grandes sistemas fluviais: geologia, geomorfologia e paleohidrologia. In: SOUZA, C. R. de G; et al. Quaternário do Brasil. Ribeirão Preto, 2005. p. 276-297.

LEMOS, R. C. e SANTOS, R. D. Manual de Descrição e Coleta de Solo no Campo. Campinas: Sociedade Brasileira de Ciência do Solo. 2a ed, 1982. 46 p. LEOPOLD, L. B.; WOLMAN, M. G.; MILLER, J. P. Fluvial processes in Geomorphology. São Francisco: W. F. Freeman and Co., 1964. 522p.

LIMA, C. R. Urbanização e intervenções no meio-físico na borda da Bacia Sedimentar de São Paulo: uma abordagem geomorfológica. 1990. $105 f$. 
Dissertação (Mestrado em Geografia Física). Departamento de Geografia FFLCH - USP. São Paulo, 1990.

MANGELSDORF, J; SCHEURMANN, K.; WEIB, F. H. River Morphology: a guide for geoscientists and engineers. Berlin: Springer, 1990. $243 \mathrm{p}$.

MARQUES, J. S. Ciência Geomorfológica. In: GUERRA, A T. \& CUNHA, S. B. Geomorfologia: uma atualização de bases e conceitos. Rio de Janeiro: Bertrand Brasil, 1994. p. 23-50.

MELO, M. S. de; VINCENS, A.; TUCHOLKA, P. Contribuição à cronologia da Formação Itaquaquecetuba - SP. In: Anais da Academia Brasileira de Ciências, 57, v.2. 1985. p. 175-181.

; PONÇANO, W. L.; MOOK, W. G.; AZEVEDO, A. E. G. de. Datações C14 de sedimentos quaternários da Grande São Paulo. In: 1 CONGRESSO ABEQUA. Anais... Porto Alegre: UFRGS, 1987. p. 427-436.

; COIMBRA, A.M.; RICCOMINI, C. Evolução do conhecimento sobre a Geologia da Bacia de São Paulo na década de oitenta. In: Workshop geologia da Bacia de São Paulo. São Paulo. Coletânea das comunicações... São Paulo, IGUSP/SBG, 1989. p. 1-11.

MIALL, S. A. Fluvial Sedimentology: an historical review. In: Miall, A. D. (Ed.). Fluvial sedimentology. Calgary: Canadian Society of Petroleum Geologists, 1978. p. 1-47.

Analysis of fluvial depositional systems. Tulsa, Okla: AAPG Bookstore, 1982. 75p.

. The Geology of fluvial deposits: sedimentary facies, basin analysis and petroleum geology. New York: Springer-Verlag Berlin Heidelberg, 1996. 582p. 
MORISAWA, M. Rivers: form and processes. London and New York: Longman, 1985. 222p.

NANSON, G. C. Point bar and floodplain formation of the meandering Beatton River, northeastern British Columbia, Canada. Sedimentology, n. 27, 1980. p. 329.

NIR, D. Man, a geomorphological agent: an introduction to Anthropic Geomorphology. Boston: D. Reidel publishing Co. and Jerusalem: Keter publishing house, 1983. $165 \mathrm{p}$.

OKEKE, F. I. Review of Digital Image Orthorectification Techniques. Gisdevelopment, Image Processing, 2006. Disponível em: $<$ http://www.gisdevelopment.net/technology/ip/fio_1.htm>. Acesso em 03 fev. 2010.

OSEKI, J. H. A fluvialidade do rio Pinheiros. Revista de Pós-Graduação em Arquitetura e Urbanismo da FAUUSP, São Paulo: Comissão de Pósgraduação-FAU-USP, n.8, 2000. p. 168-177.

OSTERKAMP, W. R. Annotated Definitions of Selected Geomorphic Terms and Related Terms of Hydrology, Sedimentology, Soil Science and Ecology. Reston, Virginia: Open File Report 2008-1217, 2008. 49 p.

OUCHI, S. Response of alluvial rivers to slow active tectonic movement. Geological Society of America Bulletin, v. 96, 1985. p. 504-515.

PELOGGIA, A. U. G. A ação do Homem enquanto ponto fundamental da Geologia do Tecnógeno: Proposição teórica básica e discussão acerca do caso do Município de São Paulo. Revista Brasileira de Geociências, 27, v. 3, 1997. p. 257-268. 
PETRONE, P. (org.). Pinheiros: aspectos geográficos de um bairro paulistano. (Relatório do Curso de Orientação para a Pesquisa), São Paulo: Ed. da Universidade de São Paulo, 1963. 196 p.

RICCOMINI, C.; TURCQ, B; SUGUIO, K. The record of continental sedimentation in Southearstern Brazil during the last millennium: paleoseismicity, the little ice age, and man. Anais da Academia Brasileira de Ciências, n. 63, 1991. p. 90.

; COIMBRA, A. M.; TAKIYA, H. Tectônica e sedimentação na Bacia de São Paulo. In: Problemas geológico e geotécnicos na Região de São Paulo. São Paulo: Associação Brasileira de Águas Subterrâneas (ABAS) / Associação Brasileira de Geologia de Engenharia (ABGE) / Sociedade Brasileira de Geologia (SBG), São Paulo, 1992. p. 21-45.

; GIANNINI, P. C. F.; MANCINI, F. Rios e processos aluviais. In: TEIXEIRA, W; et al. (orgs). Decifrando a Terra. São Paulo: Oficina de Textos, 2000. p. 191-214.

; SANTA'ANNA, L. G.; FERRARI, A. L. Evolução geológica do Rift Continental do Sudeste do Brasil. In: MANTESSO-NETO, V. et al. (orgs). Geologia do continente Sul-americano: Evolução da obra de Fernando Flavio Marques de Almeida. São Paulo: Beca, 2004. p. 383-405.

RICHARDS, K. Rivers: Form and process in alluvial channels. London: Methuen \& Co. Ltd., 1985. 358p.

RODRIGUES, C. Geomorfologia aplicada: avaliação de experiências e de instrumentos de planejamento físico-territorial e ambiental brasileiro. 1997. 279f. Tese (Doutorado em Geografia Física). Departamento de Geografia FFLCH - USP. São Paulo, 1997a. 
Qualidade ambiental urbana: como avaliar?. Revista do Departamento de Geografia. n. 11, DG-FFLCH-USP, São Paulo, 1997b. p. 135-150.

- A teoria geossistêmica e sua contribuição aos estudos geográficos e ambientais. Revista do Departamento de Geografia. n. 14, DG-FFLCH-USP, São Paulo, 2001a. p. 69-77.

. Documentos geográficos: arquivos de fotos aéreas como opção de pesquisa. Memória e Energia, n. 28, 2001b, p. 26-41.

A urbanização da metrópole sob a perspectiva da geomorfologia: tributo a leituras geográficas. In: CARLOS, A. F. A. \& OLIVEIRA, A. U. de. Geografias de São Paulo: representação e crise da metrópole. São Paulo: Contexto, 2004. p. 89114.

. Morfologia original e morfologia antropogênica na definição de unidades espaciais de planejamento urbano: Exemplo na metrópole paulista. Revista do Departamento de Geografia. n. 17, DG-FFLCH-USP, São Paulo, 2005. p. 101111.

(org.) Guia de Excursão VI SINAGEO: Sistemas geomorfológicos e o impacto da urbanização na metrópole de São Paulo. VI SIMPÓSIO NACIONAL DE GEOMORFOLOGIA, Goiânia, 2006.

ROSS, J. \& MOROZ, I. C. Mapa Geomorfológico do Estado de São Paulo: Escala 1:500.000. Mapas e Relatório. São Paulo: Lab. de Geomorfologia Depto. Geografia - FFLCH - USP / Lab. de Cartografia Geotécnica - Geologia Aplicada - IPT / FAPESP, Volume I, 1997. 64 p.

SANTANA, C. L. Geomorfologia da planície fluvial do rio Ribeira de Iguape entre Sete Barras e Eldorado (SP): subsídios ao planejamento físico-territorial de áreas inundáveis. 2008. 288f. Dissertação (Mestrado em Geografia Física). Departamento de Geografia - FFLCH - USP. São Paulo, 2008. 
SANTOS, E. O. Tietê, o rio de São Paulo. In: AZEVEDO, A. A Cidade de São

Paulo. São Paulo: Companhia Editora Nacional, v. 1, 1958. p. 45-66.

SANTOS, H. G. dos; HOCHMULLER, D. P.; CAVALCANTI, A. C.; REGO, R. S.; KER, J. C.; PANOSO, L. A.; AMARAL, J. A. M. do. Caracterização Analítica. In: Procedimentos Normativos de Levantamentos Pedológicos. Brasília: EMBRAPA-SIP, 1986. p. 47-64.

SCHUMM, S. A sinuosity of alluvial rivers on the great plains. Geological Society of America Bulletin, v. 74, 1963. p. 1089-1100.

S. A. Patterns of alluvial Rivers. Annual review of earth and planetary sciences, n. 13, 1985. p. 5-27.

S. A.; MOSLEY, M. P., WEAVER, W. E. Experimental fluvial geomorphology. New York: Wiley, 1987. 413 p.

; DUMONT, J. F.; HOLBROOK, J. M. Active tectonics and alluvial rivers. Cambridge: Cambridge Univ. Press, 2002. 296p.

SEABRA, O. C. de L. Os meandros dos rios nos meandros do poder, Tietê e Pinheiros: valorização dos rios e das várzeas na cidade de São Paulo. 1987. 323f. Tese (Doutorado em Geografia Humana). Departamento de Geografia FFLCH - USP. São Paulo, 1987.

SILVA, J. P. Expansão urbana e evolução geomorfológica em remansos de reservatórios: análise comparativa de duas bacias hidrográficas em Guarapiranga, São Paulo. 2005. 122f. Dissertação (Mestrado em Geografia Física). Departamento de Geografia - FFLCH - USP. São Paulo, 2005.

STEVAUX, J. C. O rio Paraná: geomorfogênese, sedimentação e evolução quaternária do seu curso superior (região de Porto Rico, PR). 1993. 242f. Tese (Doutorado em Geologia). Instituto de Geociências - USP, São Paulo, 1993. 
SUGUIO, K. Estudo dos troncos de árvores "linhitificados" dos aluviões antigos do rio Pinheiros (SP): significados geocronológico e possivelmente paleoclimático. In: Congresso Brasileiro de Geologia, 25. Anais... São Paulo: SBG, v.1, 1971. p. 63-69.

. Introdução à Sedimentologia. São Paulo: Edgar Blucher; Ed. da Universidade de São Paulo, 1973. p. 27-129.

. Síntese dos conhecimentos sobre a sedimentação na Bacia de São

Paulo. In: Aspectos geológicos e geotécnicos da bacia sedimentar de São Paulo. (Mesa redonda) Associação Brasileira de Geologia de Engenharia (ABGE) / Sociedade Brasileira de Geologia (SBG). São Paulo: Publicação especial, 1980. p. 25-31.

. Geologia Sedimentar. São Paulo: Edgar Blucher, 2003. 400 p.

\& BIGARELLA, J. J. Ambientes fluviais. Florianópolis: Ed. da UFSC; Ed. da UFPR, 2 ${ }^{\text {a }}$ Ed. Revista, 1990. 183 p.

TAKIYA, H. Estudo da sedimentação neogênico-quaternária no município de São Paulo: caracterização dos depósitos e suas implicações na Geologia Urbana. 1997. 143f. Tese (Doutorado em Geologia Sedimentar). Instituto de Geociências - USP. São Paulo, 1997.

TRICART, J. Principes et méthodes de la géomorphologie. Paris: Masson et Cie. Éditeurs, 1965. 469p.

. Os tipos de leitos fluviais. Notícia geomorfológica, n.11, Campinas, 1966. P. 41-49.

. Ecodinâmica. Rio de Janeiro: IBGE, 1977. 97p. 
TOY, T. J. \& HADLEY, R. F. Geomorphology and reclamation of disturbed lands. Orlando: Academic press, Inc., 1987. 480 p.

VARGAS, M. Introdução à mecânica de solos. São Paulo: McGraw-Hill do Brasil, 1977, $509 \mathrm{p}$.

VERSTAPPEN, H.T. Applied geomorphology: geomorphological surveys for environmental development. Amsterdan: Elsevier Scientific Publishing Company, 1983. 473p.

WALKER, R. G. (Ed.). Facies models. Hamilton and Ontario: Geological Association of Canada, 5 $5^{\mathrm{a}}$ Ed., 1983. 211p.

WHALLEY, W. B. Properties of materials and geomorphological explanation. Oxford: University press., 1976. 60 p.

- (Ed.). Part three: material properties. In: GOUDIE, A. (org.) Geomorphological techniques. London: Unwin Hyman, $2^{\mathrm{a}}$ Ed., 1990. p. $111-$ 223. 
Material Cartográfico

COUTINHO, J. M. V. Carta Geológica da Região Metropolitana de São Paulo. São Paulo. EMPLASA. 2 folhas. Escala: 1:100.000. São Paulo, 1980.

. Carta Geológica da Região Metropolitana de São Paulo. São Paulo. EMPLASA. Folha: São Paulo. Escala: 1:50.000. São Paulo, 1984.

EMPRESA PAULISTA DE PLANEJAMENTO METROPOLITANO S/A. Mapa da Área Urbanizada da RMSP. (Sistema Cartográfico Metropolitano), São Paulo, 1972/74. Escala 1:2.000.

. Mapa da Região Metropolitana de São Paulo. (Sistema Cartográfico Metropolitano), São Paulo, 1972/74/80/81. Escala 1:10.000.

. Mapa da Região Metropolitana de São Paulo. (Sistema Cartográfico Metropolitano), São Paulo, 1974/80/81. Escala 1:25.000.

PREFEITURA MUNICIPAL DE SÃO PAULO (PMSP-SVMA-SEMPLA). Atlas Ambiental do Município de São Paulo: Mapa Geológico. In: O MEIO Físıco E A OCUPAÇÃo HUMANA. São Paulo, 2002. Disponível em <http://atlasambiental.prefeitura.sp.gov.br/?id=13>. Acesso em 19 jul 2007.

SARA BRASIL S/A. Mappa Topographico do Município de São Paulo. Roma: Instituto Geográfico de Agostini, (Folha III), 1930. Escala 1:2000. 
Sites consultados para aquisição de base cartográfica digital:

IGc: Projeto Alto Tietê, 1999 ftp://lig.igc.usp.br/ProjetoTiete/ (em 21/01/2010)

CPRM: http://mapoteca.cprm.gov.br/programas/template.php (em 21/01/2010)

IBGE: ftp://geoftp.ibge.gov.br/mapas/topograficos/topo1000/vetor/ (em $21 / 01 / 2010)$

Sites consultados para outras informações:

EMAE: http://www.emae.sp.gov.br/canais.htm (em 08/01/2010) 


\section{ANEXO 1}

\section{ETAPAS DA ANÁLISE DE AMOSTRAS EM LABORATÓRIO}

Procedimentos

seguidos no trabalho
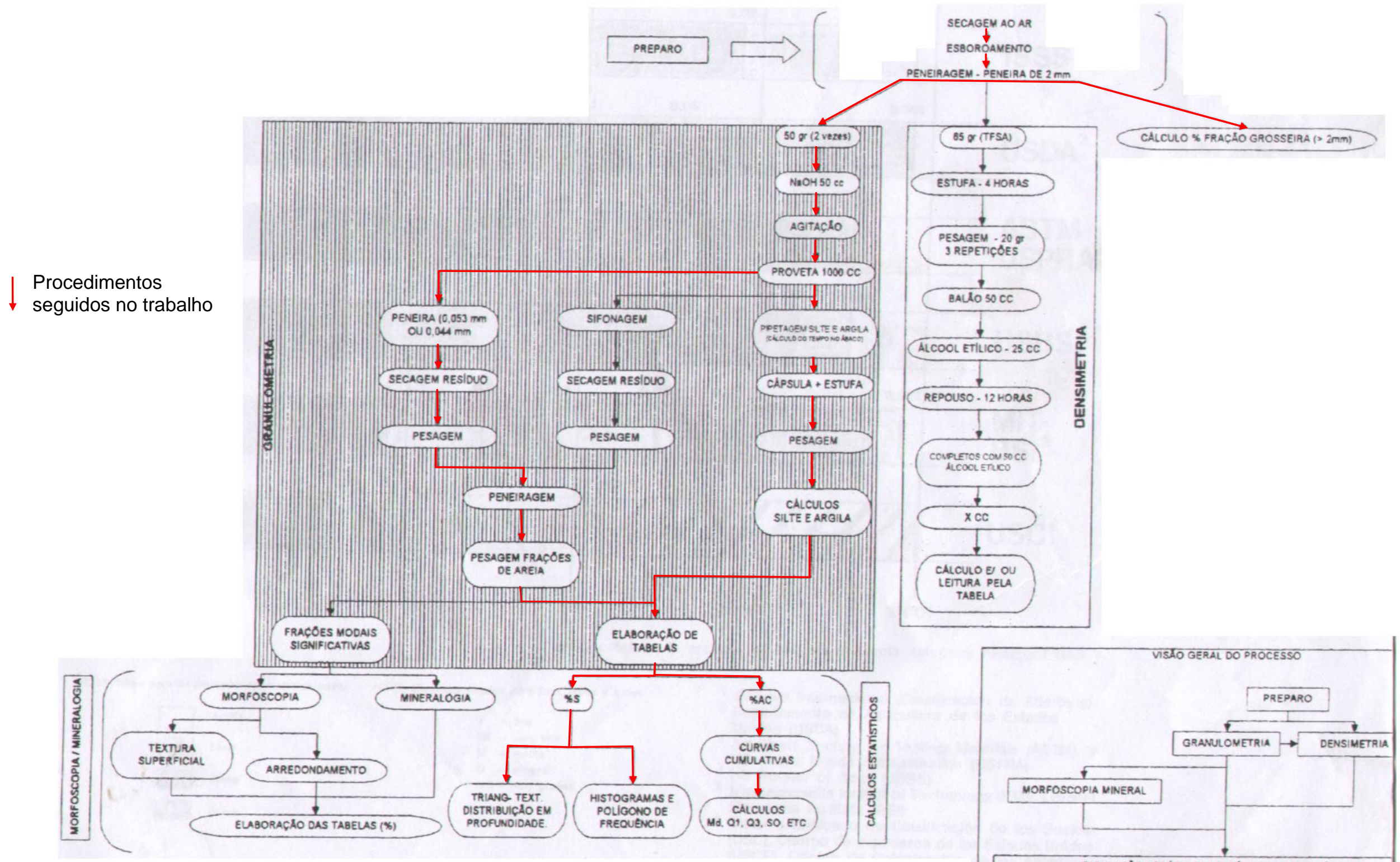

Baseado em Camargo et al. (1986), Santos et al. (1995) e Kiehl (1979).

Fonte: Material didático do curso de Estágio Supervisionado em Análise de Solos (FLG - 593. DG/FFLCH/USP). 


\section{ANEXO 2}

Amostra das sondagens geológicas fornecidas pelo Metrô.

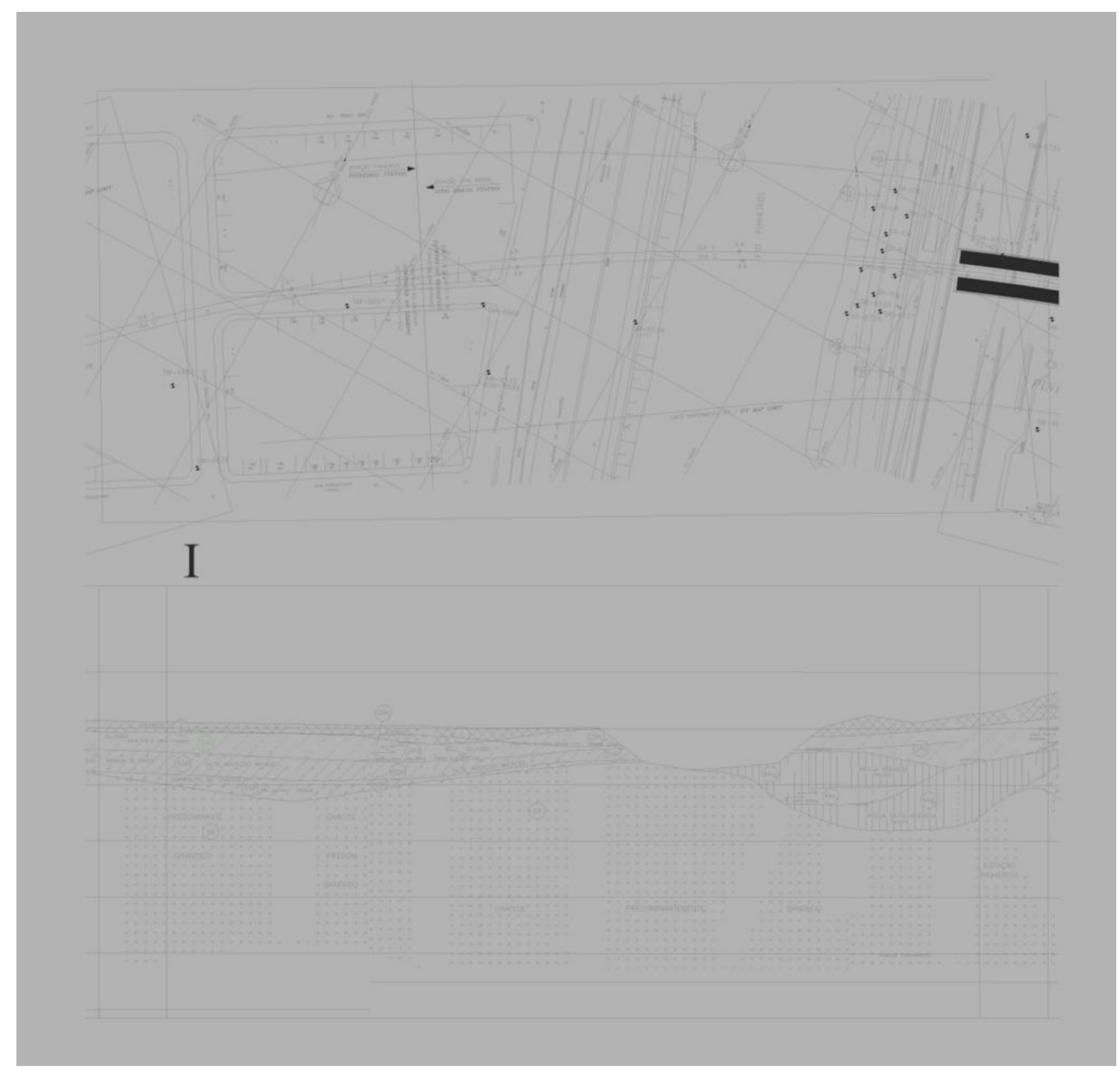


ANEXO 3

Amostra de sondagens da Rua Diogo Moreira
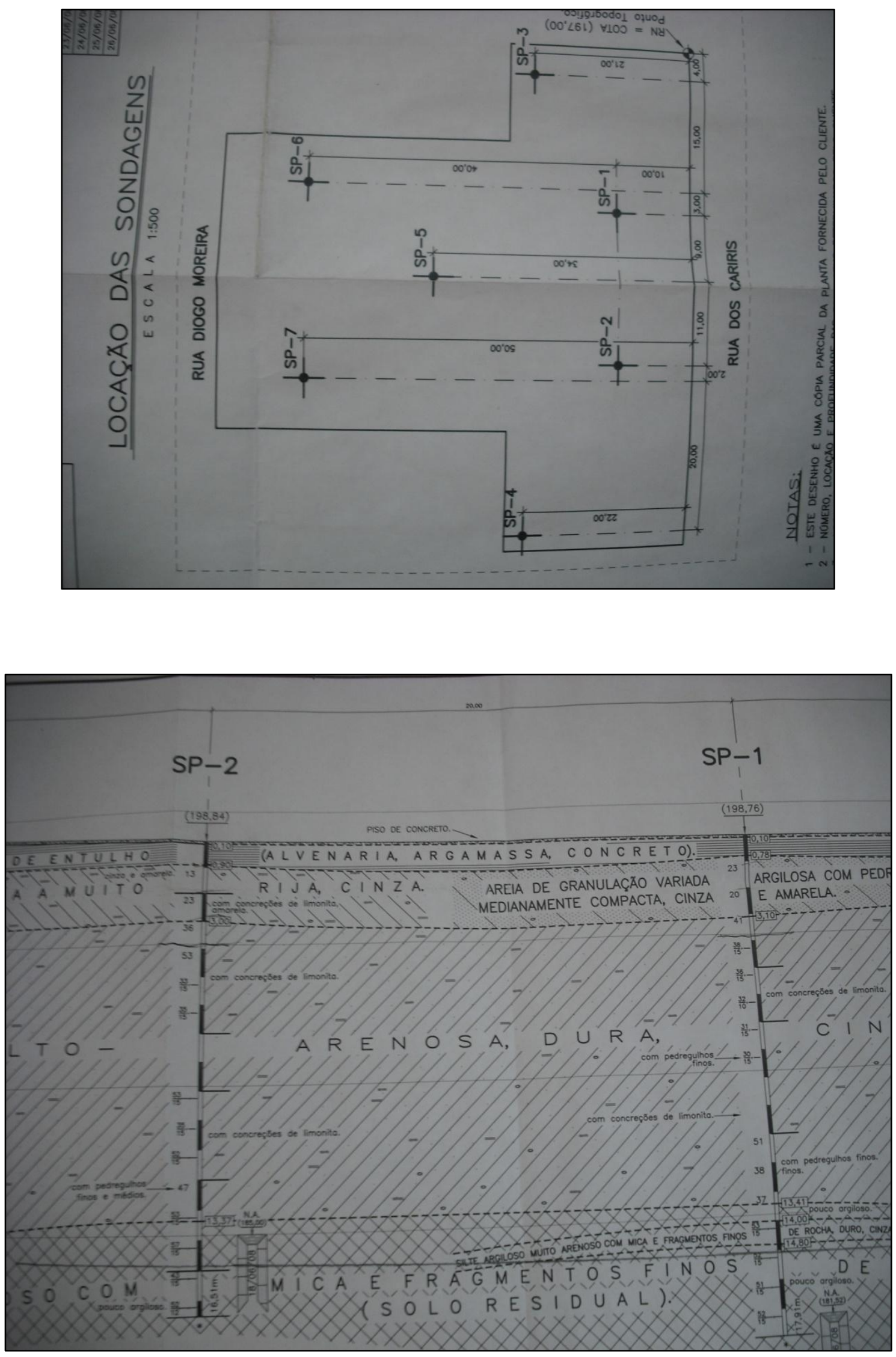


\section{ANEXO 3}

Amostra de sondagens da Rua Seridó
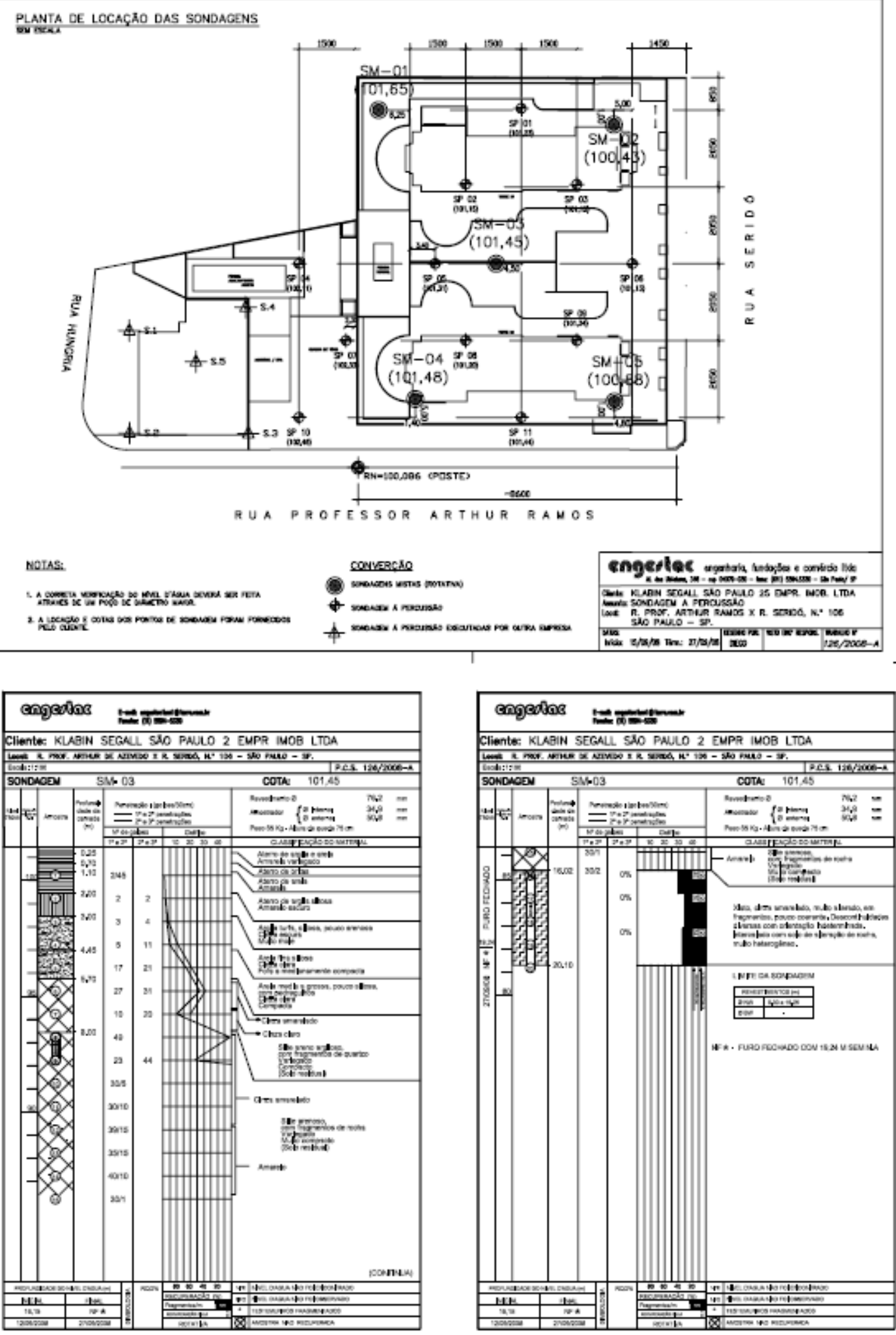